\title{
O Consentimento esclarecido na prática de enfermeiras de \\ Centros de Saúde Escola de São \\ Paulo
}

HELENA AKEMI WADA WATANABE

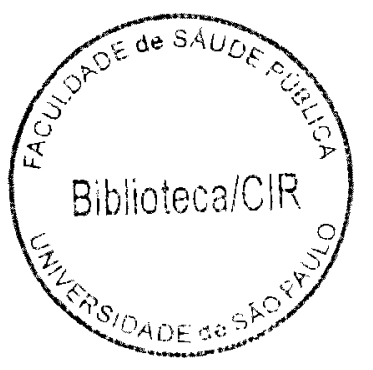

Tese apresentada ao Departamento de Prática de Saude Pública da Faculdade de Saude Pública da Universidade de São Paulo para a obtenção do Grau de Doutor em Saide Pública

Área de Concentração:

Servicos de Sauide

Orientadora: Profa. Dra. Sueli Gandolfi Dallari 
Autorizo, exclusivamente para fins acadêmicos e cientificos a reprodução total ou parcial desta tese, por processos fotocopiadores.

Assinatura:

Data:

$38985 / 99$ (tac) 
Dedico meu trabalho a

Gustavo, Guilherme, Douglas,

Norico e Tadayosi 


\section{AGRADECIMENTOS}

Os agradecimentos são inúmeros e sinceros. Primeiramente agradeço à Profa. Dra. Sueli Gandolfi Dallari, orientadora e grande incentivadora de minha atividade docente. Meu muito obrigada pela acolhida, amizade e orientação desde o Mestrado.

Aos Professores Doutores Evelin Naked de Castro Sá, Márcia Faria Westphal, Maria Cristina K. Massarollo, Maria Rita Bertolozzi e Paulo Antônio de Carvalho Fortes pela sua atenção e comentários que muito contribuíram para o desenvolvimento deste estudo.

À Profa. Dra. Djair Daniel Nakamae, com quem tive o prazer de desfrutar algumas tardes conversando, lendo e discutindo o material empírico obtido nesta pesquisa.

À Profa. Dra. Fumika Peres e à Asssistente Maria da Penha Vasconcelos, pela leitura atenta e discussão dos primeiros esboços do projeto de pesquisa.

Aos Drs. Dayse Gogliano, Leocir Pessini e Arthur Watanabe pelas indicações bibliográficas.

À Profas Dras Alice Moreira Derntl e Cleide Lavieri Martins e às amigas Lavinia dos Santos Souza Oliveira, Ana Maria Tucci G.B. Ferreira, Maria Thereza Escobar e Nur Schqair pelas oportunidades de discussão, torcida e apoio incondicionais.

À Maria Aparecida Nascimento Soares Alves, pela disponibilidade, afeto e ajuda preciosos.

À Cornélia Frota Ferreira pela presteza na tradução do resumo para o inglês.

Às enfermeiras, sujeitos deste estudo, aos diretores dos Centros de Saúde Escola e aos usuários dessas unidades, que gentilmente compartilharam comigo suas experiências possibilitando a realização da pesquisa.

Ao funcionários da CPG pela atenção, carinho e presteza todas as vezes que necessitei.

Aos funcionários da Biblioteca da Faculdade de Saúde Publica, sempre atentos e disponiveis, inclusive na busca de alguns artigos que necessitei para a elaboração deste trabalho.

Ao pessoal do xerox que não mediu esforços para que eu pudesse cumprir os meus prazos. 
Às colegas do Direito Sanitário: Marília, Livia e Eli, pelo incentivo.

À meus familiares, que acompanharam e deram suporte para meu aprimoramento, principalmente proporcionando-me tempo e tranqüilidade para a realização deste estudo. A meus pais Tadayosi e Norico, que demonstram dia-a-dia o valor do verdadeiro amor parental, sempre me apoiando e oferecendo suporte. À minha sogra Maria, que junto com meus pais cuidou das crianças sempre que precisei. Às minhas irmãs Neide e Heloisa e meus cunhados Arthur, Lairce, Paulo e Celso, pela torcida, carinho e disponibilidade para tantas coisas: discussões, preparação de aula, cuidar dos sobrinhos, etc.

A meus filhos Gustavo e Guilherme, que acompanharam todo o processo de "fazer doutorado", pela compreensão, à seu modo, de minhas freqüentes ausências e necessidade de silêncio e tranqüilidade.

À Vera Ruth Sabino Ferreira, que pacientemente sentou comigo durante esses anos todos ajudando-me na busca da compreensão e integração de meus diferentes papéis.

À Marie Azuma Rodrigues e Yumiko Asada Jácomo pela amizade e incentivo.

À Albertina Moraes pelo cuidado com o nosso espaço.

E finalmente, a Douglas, por sua presença, dedicação, suporte e vibração em tudo que faço. 


\section{RESUMO}

WATANABE, H.A.W. O Consentimento esclarecido na prática de enfermeiras de Centros de Saúde Escola de São Paulo. São Paulo; 1999 [Minuta da tese de Doutorado - Faculdade de Saúde Pública das USP.

As mudanças sociais ocorridas nas últimas três décadas fizeram com que o respeito à autonomia do usuário e o direito ao consentimento livre e esclarecido assumissem posição de destaque na ética em saúde e fossem incorporados aos Códigos de Ética Médica e de Enfermagem vigentes no pais. Estudos desenvolvidos em serviços de saúde, mormente os hospitalares, têm evidenciado que os usuánios obtêm poucas informaçōes sobre suas condiçōes de saúde, tratamento, cuidado e que a prática profissional tem oscilado entre o paternalismo, o autoritarismo e o respeito à autonomia. Esta investigação foi realizada com o objetivo verificar como o consentimento esclarecido é concebido na prática das enfermeiras de quatro Centros de Saúde Escola (CSE) de São Paulo. A análise do material empirico, obtido através de entrevistas junto a essas profissionais foi feita à luz da ética principialista. $O$ resultados demonstram que essas profissionais, apesar de desconhecerem o termo consentimento esclarecido, respeitam as suas normas básicas, reconhecem o direito dos usuários em participar de decisões que digam respeito à sua saúde, oferecem informações para subsidiar essas decisōes. O padrão de informação é personalizado, porém. alternativas de decisão, além daquelas estipuladas em programas e protocolos, raramente são apresentadas. Assim, o consentimento esclarecido na prática das enfermeiras em CSE é limitado por esses programas e protocolos. As enfermeiras têm como preocupação o beneficio do usuáno, o estímulo às participação dos usuários no seu cuidado e a prevenção ou remoção de niscos e danos. No geral, estas enfermeiras acatam a decisão tomada pelo usuário, mesmo quando há recusa em seguir a orientaçāo dada, mas por vezes demonstram dificuldade em aceitá-la quando a mesma põe em risco a saúde de terceiros. Enquanto profissionais que participam na implementação politicas de saúde demonstram preocupaçāo com sua "missāo", sentem-se impotentes e demonstram desconhecer aliados e instrumentos que poderiam ser utilizados nessa situação.

Palavras chave: consentimento informado, enfermagem de saúde pública, ética em enfermagem. 


\section{SUMMARY}

WATANABE, H.A.W. The role played by the informed consent in the nurses' practice at School/Health Centers in São Paulo. São Paulo, SP, Brazil, 1999 [Tese de Doutorado- Universidade de São Paulo Faculdade de Saúde Pública].

The social changes occurred in the last three decades were instrumental for causing the customers' autonomy and right to free-informed consent to be respected assuming a leading rank in the health ethics as well as being incorporated into the Nursing and Medical Ethical Codes in force in the country. Studies carried out in health services, moreover in hospital facilities, disclosed that the customers usually obtain few information on their health condition, treatment and, care and that the professional practice has been oscillating among being either paternalistic, authoritarian or respectful regarding the patient's autonomy. The purpose of this investigation was to ascertain how the informed consent is conceived by the nurses' practice in four School/Health Centers in São Paulo, State of Sāo Paulo, Brazil. The empincal material obtained in interviews along with these professionals was analyzed in the light of Bioethics principles. Results were as follows: these professionals do not know the term informed consent, however, they act in accordance with its basic norms, recognizing the customers' right to participate in the decision-making regarding their health, besides providing information in order to subside these decisions; the pattern of the information provided is personalized, although decision alternatives other than those stipulated in programs and protocols are rarely presented. Informed consent, in nursing practice in School/Health Centers is restricted within these programs and protocols. These nurses are concerned about users' beneficence, their participation in self care and about preventing or removig risks or harm. In general, these nurses respect the decision taken by the customers, even when they refuse to comply with the orientation provided, however showing sometimes difficulties in accepting it when the health of a third-part is in jeopardy; while professionals participating in the implementation of health policies, they demonstrate being concerned with their "mission", sometimes feeling themselves impotent to deal with this situation, disclosing therefore a lack of knowledge concerning allied institutions and instruments which might be used to face these kind of circumstances.

Key words: informed consent; public health nursing, nursing ethics 


\section{ÍNDICE}

1. Introdução

1.1. Introduzindo a temática 2

1.2. A ética codificada e o ensino da ética em enfermagem 6

1.3. Saúde coletiva e a prática de enfermagem 16

$\begin{array}{ll}\text { 2. Objetivos } & 21\end{array}$

3. Método 23

3.1. Referencial teórico: os principios da Bioética 24

3.1.1. Beneficência 27

Paternalismo $\quad 29$

3.1.2. Não maleficência $\quad 32$

3.1.3. Autonomia 34

Consentimento Esclarecido $\quad 39$

3.14. Justiça 47

3.2. Procedimentos metodológicos 51

3.2.1. O Campo de estudo e sujeitos da pesquisa 53

3.2.2. As estratégias de coleta e análise de dados 54

4. Resultados e análise 62

4.1. O campo de estudo 63

4.2. Os sujeitos da pesquisa $\quad 75$

4.3. Análise dos temas 79

- Decisão sobre o cuidado $\quad 81$

Quem decide $\quad 81$

Instrumentos para decidir $\quad 93$

- Prestação de assistência $\quad 105$

A inidivíduos 105

Familiares e coletividade $\quad 111$

Conduta frente à decisāo $\quad 124$

5. Conclusōes 133

6. Consideraçāo finais 141

$\begin{array}{ll}\text { 7. Referências bibliográficas } & 149\end{array}$

8. Anexos 
Intraduçãa 


\section{INTRODUÇÃO}

\subsection{INTRODUZINDO A TEMÁTICA}

Em nossa prática assistencial, de pesquisa e de ensino em saúde coletiva, experienciamos e observamos o dia a dia de vários serviços de saúde, o que nos tem levado a refletir sobre a relação entre o profissional enfermeiro e os usuários na sua prática assistencial nesses serviços, considerando a sua atitude ética para com os mesmos.

Observamos empiricamente que no cotidiano de uma unidade local de saúde, alguns profissionais de enfermagem desenvolvem ações junto aos usuários, de forma impessoal, rotinizada, seguindo normas e procedimentos padronizados voltadas para a patologia e a sintomatologia, em detrimento da pessoa como um todo: suas crenças, seus conhecimentos, sua cultura, seu modo de vida. Muitas vezes as pessoas são tratadas apenas como mais um curativo, uma inalação, um caso de diabetes ou de hipertensão, um caso novo de tuberculose ou um surto de hepatite em uma creche, que devem ser assistidos de acordo com as normas existentes.

Entendendo as atividades de saúde dentro de um enfoque de responsabilidade social e que devem possibilitar a ampliação dos direitos de cidadania, como diz GARRAFA (1994), a relação profissional-usuário deve ser tal que considere cada pessoa como cidadão autônomo e que propicie sua participação ativa nas decisões que digam respeito ao seu bem estar físico e psíquico. 


\section{Introduçãa}

$\mathrm{Na}$ área da saúde, a autonomia do usuário se expressa através do consentimento esclarecido ${ }^{1}$ ou informado ou ainda pós informado, que é entendido como uma autorização autônoma de um individuo para uma intervenção, cuidado ou envolvimento em pesquisa. (BEAUCHAMP E CHILDRESS, 1994:145)

PELICIONI (1989), em estudo sobre a opinião de usuários sobre serviços de saúde verificou que aproximadamente $33 \%$ deles referiram não conseguir realizar perguntas a respeito de sua saúde e de seu tratamento por dificuldades pessoais como timidez, pressa, esquecimento, medo do médico, auto-suficiência e dificuldades de comunicação com os profissionais de saúde, mormente o médico, por diferença de linguagem ou devido à postura do profissional, que não permite ao usuário fazer colocações. Relata também que alguns usuários estavam insatisfeitos com o serviço devido à falta de atenção dos profissionais, que não os entendem ou escutam.

GERMANO (1993) relata casos em que algumas enfermeiras se abstiveram de qualquer manifestação frente ao desrespeito ao direito de decisão sobre seu cuidado em nivel hospitalar como no caso de pessoa que foi submetida a intervenção cirúrgica sem saber previamente qual o tipo de procedimento seria adotado; suspensão de cirurgias sem que o paciente fosse informado da causa, etc.

\footnotetext{
${ }^{1}$ Optamos neste estudo pela utilizaçāo do termo "consentimento esclarecido" que em nosso meio foi firmado pela Resolução 196 de 10 de outubro de 1996 do Ministério da Saúde.
} 
Segundo a enfermeira Francisca Valda Silva de Oliveira, presidente da Comissão de Legislação da Associação Brasileira de Enfermagem Nacional (1989-92), citada por GERMANO (1993 p.59):

\begin{abstract}
“Não existe nos serviços de saúde relação democrática, digna que respeite em geral o ser humano, pois a organização é fundada na hierarquização; fragmentaçăo; competição e trabalho individualizado; preconceito; discriminação racial, sexual, social. Há uma postura de onipotência, arrogância entre os profissionais, tal qual a prática de obediência/cooperação para manter o status quo e impedir a critica social, entre tantas outras distorções e desvios".

“O compromisso se dá de forma fisiológica e clientelista com o empresáno do setor saúde, dingentes sanitánios, instituiçōes, subjugando clientes/usuários aos interesses econômicos, políticos, ideológicos vigentes em detrimento de uma assistência à saúde que respeite o direito constitucional de cidadania".
\end{abstract}

COELHO (1993), em estudo, sobre a responsabilidade ético legal dos enfermeiros, verificou que as enfermeiras consideram o poder dos pacientes tomarem decisões sobre seu tratamento e saúde, como um direito a ser conquistado, e que o poder decisório tem se centralizado nos profissionais de saúde, mormente no médico que detém a responsabilidade pelo diagnóstico.

Segundo a autora: "as bases informativas e legais para obtenção de consentimento informado por pacientes são pouco discutidas dentre os profissionais de saúde. As enfermeira têm pouca clareza sobre a quem compete $\circ$ quê em situações da assistência que requerem independência e respeito frente à clientela." (COELHO, 1993) 


\title{
Totroducãa
}

Em estudo realizado junto a pacientes previdenciários, (SILVA citado por SIQUEIRA, 1985) verificou-se que havia uma dificuldade dos pacientes se pronunciarem:

\begin{abstract}
"sobre suas necessidades de saúde, suas aspiraçōes e frustraçōes, intimidados com a 'precisão' e 'confiabilidade' do discurso técnicoburocrático. Alem disso, o caráter ideológico da relação médico/paciente - qualificaçāo/submissão - acionado pelas normas, discursos e ritos das instituiçōes médicas, tornam mais dificil ao paciente expressar suas opiniōes".
\end{abstract}

Assim, naturaliza-se a situação em que o usuário passa a ser mera forite de informaçōes, objeto sobre o qual o profissional vai aplicar os procedimentos por ele escolhidos, sem esclarecimento e consulta, dentro de uma relação pedagógica autoritária, entre alguém que sabe e decide e outro que não sabe e recebe "prescrições" e procedimentos, que não tem direito de ser esclarecido e nem capacidade para decidir sobre nada. No caso de hospitais, o consentimento era, ou ainda é obtido dentro da visão legalista, isto é, preenche-se e assina-se um formulário chamado "termo de responsabilidade".

Em estudo recente em serviço hospitalar, FERREIRA (1998), verificou que os pacientes internados não receberam informações sobre riscos, benefícios e conseqüências da assistência de enfermagem, que as informações oferecidas eram 


\title{
Introduceãa
}

pouco claras e insuficientes e que se caracterizavam como descriçōes dos procedimentos a serem realizados.

FORTES e col. (1997) em estudo sobre a informação em saúde a adolescentes e idosos, verificaram que a conduta dos profissionais de saúde oscila entre o paternalismo e o respeito à autonomia, e que

\begin{abstract}
"em nosso sistema de saúde não somente ocorre uma legitimação do comportamento paternalista dos profissionais de saúde, mas também uma postura e condutas freqüentes de desrespeito aos direitos do cidadão enquanto usuário dos serviços de saúde,..."
\end{abstract}

Os autores afirmam que as normas deontológicas são insuficientes para dar conta da atuação cotidiana da atividade das diversas categorias de trabalhadores que atuam no setor saúde. (Fortes e col. 1997)

A questão do relacionamento profissional-usuário na prática da obtenção do consentimento esclarecido consta implicitamente do Código de Ética dos Profissionais de Enfermagem desde 1993 (BRASIL, 1993), bem como no Código de Defesa do Consumidor desde 1992. Entretanto, vários estudos mostram que a participação do usuário nas decisões sobre seu cuidado não lhe é facultada. Segundo ALMEIDA (1991), o profissional tende a reproduzir uma imagem de que não adianta esclarecer porque o usuário não tem capacidade de entender ou de tomar resoluçōes acerca de sua saúde. Dessa forma, não se dá ao trabalho de esclarecer e muito menos de possibilitar a participação do usuário nas decisões que digam respeito ao seu cuidado. 


\section{Toutraducẽäa}

As razões de termos elegido Centros de Saúde Escola (CSE) como locais para o desenvolvimento deste estudo estão relacionadas ao papel por elas assumido.

Por se tratarem de unidades assistenciais ligadas a instituições de ensino superior, apresentamos sucintamente como se deu a criação de tais unidades, no sentido de entendermos o seu papel, assim como a posição dos profissionais de saúde que aí desenvolvem suas práticas.

Devemos lembrar que as instituições de ensino superior têm por função o ensino, a pesquisa e a prestação de serviços à comunidade. Historicamente, algumas dessas instituições, que tinham como objetivo a formação de profissionais da área da saúde, criaram ou assumiram serviços de prestação de assistência, mormente serviços públicos, com o objetivo de servirem de campo de ensino da prática profissional e de pesquisa.

Os Centros de Saúde Escola do Estado de São Paulo, criados através de convènios entre a Secretaria de Estado da Saúde e universidades ou faculdades, sāo serviços que originalmente tinham por finalidade constituir-se em "modelo", local de experimentação de novas propostas de intervenção em saúde coletiva, de formação de alunos dos cursos da área da saúde, em nível de graduação e de pós graduação (senso lato e estrito), integrando a rede de serviços públicos e desenvolvendo ações básicas de saúde definidas nos convênios. Hoje, tomam parte no Sistema Único de Saúde e têm como objetivos principais, prestar assistência à comunidade, servir de campo de estágio, residência ou aprimoramento, participando da 


\section{Tutroducāa}

formação de profissionais de saúde e servindo de local para o desenvolvimento de pesquisas e de novos modelos e tecnologias em saúde.

A escolha de CSEs tem dupla significação: a primeira, por constituir-se em local de formação de profissionais da saúde, espera-se, que apresentem diferenças em relação a outras unidades da rede de serviços. A segunda, por ser parte de uma rede pública de serviços e atender grupos sociais que geralmente apresentam dificuldades de acesso e consumo, podendo se enquadrar no caso em que a não participação do usuário nas decisões sobre sua saúde pode se "naturalizar".

\subsection{A ÉTICA CODIFICADA E O ENSINO DA ÉTICA EM ENFERMAGEM}

Considerando que o objeto de nosso estudo, relaciona-se diretamente ao respeito à autonomia, do usuário e ao direito de participação nas decisões nos parece oportuno lançar um breve olhar sobre a ética codificada e o ensino referente à relação profissional-usuário, conteúdo obrigatório da disciplina de "ética em enfermagem" e sobre a evolução dos códigos de ética em enfermagem no Brasil.

O ensino de enfermagem, historicamente, tem se pautado, de forma predominante, pela valorização da teoria e da técnica, que tem como principios, a objetividade e a neutralidade. Como diz Saul (1988) "Neste paradigma técnico-linear, de cunho mecanicista, o perfil do profissional que, por hipótese implica uma projeção da competência profissional, è a construção idealizada, apriorística, definida em uma área de conhecimento." 
A conformação desse perfil se dá atravès da análise de tarefas do profissional, que leva à defirição de objetivos comportamentais a serem atingidos. Estas metas operacionais geram a definição de conhecimentos, habilidades e atitudes que o profissional deve exibir (Saul, 1988).

Para maior compreensão da tendência dominante e partindo do pressuposto de que qualquer que seja a prática profissional, ela é historicamente condicionada, cremos ser necessário fazer um breve histórico da enfermagem moderna².

A enfermagem moderna surge no século $X I X$, junto com o nascimento da clínica e a institucionalização do hospital. passando a ter como finalidade, o controle do meio ambiente do paciente, incorporando a disciplina com a finalidade de normalizar e regulamentar toda a vida do hospital (Almeida; Rocha, 1984). Emerge assim, a necessidade de treinar formalmente o pessoal do hospital. É desta forma que Florence Nightingale, dama da aristocracia inglesa, instituiu uma escola de enfermagem que admitia duas categorias de alunas: as "lady-nurses" e as "nurses", diferenciadas conforme sua classe social, desde então, separando o trabalho "intelectual" do "manual". Essas alunas deveriam morar na escola, dado que se considerava importante o "treinamento moral e do caráter....um mínimo de condições educacionais e um máximo de elevação moral". Ela legitimou a hierarquia e a disciplina do trabalho em enfermagem e introduziu o modelo vocacional.

\footnotetext{
2 ALMEIDA, M.C.P.; ROCHA,J.S.Y.(1986 p.36-58) fizeram um histórico detalhado da enfermagem desde o seu "surgimento" na era cristă, impregnada de ideais de "fraternidade, serviço, caridade e auto-sacrifício" assistindo os doentes, os necessitados e os moribundos, como forma de salvação de sua alma através da salvação da alma dos outros, até a introdução do capitalismo, e a institucionalização da enfermagem e do ensino da enfermagem moderna com Florence Nightingale. Cristina Melo, (1986) e Delvair de Brito (1987) fazem um histórico da enfermagem no Brasil, desde o surgimento da primeira escola de enfermagem segundo os moldes norte americano, baseado no Sistema Nightingale.
} 


\section{Toutraduçãa}

No Brasil, a primeira escola de enfermagem é criada em 1923, reproduzindo a divisão do trabalho intelectual e manual, introduzida por Nightingale, e que perdura até os dias de hoje: as enfermeiras, em menor número e pessoal auxiliar em maior número, cabendo às primeiras exercer principalmente atividades de ensino e de supervisão do pessoal auxiliar, a quem caberia executar a assistència direta ao paciente.

Como a assistência direta era, e continua sendo, prestada basicamente por este pessoal, nas primeiras décadas deste século, foram desenvolvidos instrumentos e técnicas de enfermagem voltados para os procedimentos a serem executados, no sentido de viabilizar esse controle. A enfermagem centra sua atenção nas tarefas e procedimentos e não no doente em si (Almeida \& Rocha, 1986).

O ensino centrado em procedimentos devia desenvolver na estudante respeitabilidade, obediência, delicadeza, submissão, destreza no trabalho pesado, lealdade, passividade e religiosidade.

Ainda hoje, cumprindo sua função de reprodução e manutenção do status quo, o ensino de enfermagem vem privilegiando o enfoque tecnicista, funcionalista e de assistência ao individuo hospitalizado, ressaltando a dicotomia saúde/doença, prevenção/cura, assistência hospitalar/saúde pública.

Neste cenário, a ética tem feito parte do currículo de enfermagem desde a organização e estruturação do primeiro curso de Enfermagem no Brasil em 1923, tornando-se disciplina obrigatória a partir de 1972 (Res. 4 CFE). Objeto de preocupação da categoria, sempre foi reconhecido como elemento básico na formação da enfermeira. Foi tema de discussão em vários congressos (nove, tendo sido tema oficial em três), semanas de enfermagem e de vários artigos e trabalhos científicos publicados. (GERMANO, 1993). 


\section{Tutroduceãa}

Em 1954 a Associação Brasileira de Enfermagem, com o objetivo de orientar as escolas do Brasil, publicou um programa de ensino de ética, que segundo GERMANO (1993: 117-127), baseava-se no estudo dos deveres da enfermeira. direcionado para uma religiosidade, conservadora e conformista que trazia como conseqüências a obediência e a subserviência.

Assinala ainda que em meados desta década, o ensino da ética era, predominantemente legalista, normativo, centrado na Legislação e Código de Ética. E informa que os programas de disciplina e a bibliografia adotada nos diversos cursos seguiam essa tendência. (GERMANO, 1993:122-125).

Ainda em relação ao ensino, BARROS E SILVA (1990:126) , verificaram, no inicio dos anos 90 , que a prática pedagógica era "... em sua maioria, autoritária, distante da realidade da prática dos serviços de saúde e acrítica,..."

Apesar da importância que se dá ao ensino da ética nos cursos de enfermagem, a carga horária destinada a disciplinas a ela relacionada tèm variado de 30 a 60 horas. Entretanto, como assinala GERMANO (1993), "Os professores em suas diferentes disciplinas transmitem uma ética que enforma a ação do estudante e se projeta posteriormente no exercício da profissão"

Além disso, GERMANO (1993) afirma que a grande maioria dos docentes de ètica observam: 


\section{Tutroduceãa 12}

“....uma falta de motivação por parte desses (alunos de enfermagem). principalmente no inicio dos cursos. Esse desinteresse inicial vai gradativamente desaparecendo, segundo os professores, à medida que as reflexões e discussōes tocam as questões da prática profissional" (GERMANO. 1993:120)

Assim, é a prática, o contato com a realidade das relaçōes interpessoais e profissionais. que motivam e instigam os profissionais de saúde em formação, trazendo subsídios para a discussão e reflexão ética.

Os códigos de ética dos profissionais de saúde, um dos conteúdos das disciplinas de ética em enfermagem, preconizam direitos e deveres na prática profissional, sugerem que o ato profissional deve ser julgado por seus pares, buscando preservar o individuo, a familia e a comunidade, objetos finais de suas ações, da negligència, da omissão ou outras falhas.

O primeiro código de ética de enfermagem, aprovado em 1958, teve como base três concepções: a visão religiosa, o servir como papel da enfermeira e a obediência aos médicos e às autoridades constituidas. Em suma, apenas veio para sacramentar o que vinha ocorrendo na prática das profissionais. (PASSOS, 1995)

Em 1973 foi sancionada a lei que criou os Conselhos Federal e Estaduais de Enfermagem. O código de Deontologia de Enfermagem, aprovado em 1975 e publicado no ano seguinte, continuou seguindo uma orientação metafísica. de obediência às autoridades, de guardiã que serve e zela. A ética codificada de enfermagem continuou tendo Deus como a origem da moralidade, isto é, as normas derivam de um poder "sobre-humano" (GERMANO, 1993:48). 
Segundo com PASSOS (1995)

"As profissionais de enfermagem não onentavam suas açōes por normas surgidas da sua prática cotidiana, nem do seu envolvimento social. Do mesmo modo, sua ação não visava atingir o homem concreto,...., sua orientação continuava sendo teórica e idealista".

Em 1979, foram aprovados o Código de Infrações e Penalidades e o Código de Processo Ético cujos objetivos eram o de orientar o Conselho Federal de Enfermagem (COFEN), quanto aos procedimentos éticos na aplicação do Código de Deontologia.

$\mathrm{Na}$ década de 80 , setores da enfermagem se engajam nos movimentos sociais pela redemocratização do país e as discussões acerca do Código de Deontologia de Enfermagem foram ampliadas, voltando-se para outras correntes da ética, aprofundando a análise crítica da ética profissional convencional, normativa, dogmática, policialesca, que define $\circ$ comportamento ideal para os trabalhadores de enfermagem exteriormente à história de seu processo e das suas relações de trabalho na atual estrutura de saúde (OLIVEIRA apud GERMANO, 1993: 52).

Já o Código de Ética aprovado em 1993 e em vigência tem como fonte de inspiração, os princípios gerais da Declaração Universal dos Direitos Humanos e deixa de lado a orientação dada pelas associações religiosas, caracterizando-se por uma mudança de foco, considerando prioritariamente a

"necessidade e o direito de Assistência de Enfermagem da população, os interesses do profissional e sua organização. Está centrado na 


\section{Tutroduçãa}

clientela e pressupõe que os Agentes de Trabalho da Enfermagem estejam aliados aos usuários na luta por uma assistência de qualidade sem riscos e acessível a toda população" (BRASIL, 1996).

Este Código de Ética traz modificações significativas no que diz respeito a conquistas sociais tanto para os profissionais de enfermagem quanto para a população em geral. Por exemplo, incluiu-se um capítulo de direitos do profissional, tais como recusar-se a executar atividades que não sejam de sua competência legal, ser informado sobre o diagnóstico dos pacientes sob seus cuidados, ter direito de associar-se, o de participar de movimentos reivindicatórios por melhores condições de trabalho e remuneração, e de aprimorar-se atualizando seus conhecimentos.

Em relação aos pacientes/clientes, o capitulo dos deveres coloca que a assistência de enfermagem deve ser prestada de forma contínua, sem discriminação de qualquer natureza, livre de riscos decorrentes de imperícia, negligência ou imprudência. Informaçōes acerca da assistência de enfermagem, possiveis riscos e benefícios e conseqüências que possam ocorrer, devem ser prestadas, bem como deve-se respeitar e reconhecer o direito do cliente decidir sobre sua pessoa, seu tratamento e seu bem estar (art. 26 e 27). Devem ser garantidos o respeito ao pudor, privacidade e intimidade do cliente e o segredo de fato sigiloso que tenha conhecimento em razão da atividade profissional (Art 28 e 29). 
Em relação à realização de pesquisas que envolvam o paciente, o profissional deve obter o seu consentimento, ou de seu representante legal, após ser devidamente informado sobre

"objetivos, riscos e benefícios, da garantia de anonimato, sigilo, respeito à privacidade, intimidade e liberdade de participar ou não no momento que desejar." (Art 35)

O profissional é proibido de participar de tratamento (Art44), bem como executar assistência de enfermagem sem o consentimento do cliente ou de seu representante legal exceto em iminente risco de vida (Art 49).

Outro ponto importante apontado por GERMANO (1993; 57-58) foi a transformação do Código de Infrações e Penalidades em um capítulo (Capítulo VII), rompendo com a característica fortemente legalista que "obrigava" o profissional a ser ético.

Embora reconheçamos que os valores morais seguem as transformaçōes ocorridas na sociedade e que a ética codificada, muitas vezes, impõe regras de conduta dessa sociedade a individuos dotados de consciência e de capacidade de decisão, é preciso assinalar, conforme afirma PASSOS (1993), que

"a incorporação dos valores da sociedade à consciência dos indivíduos e à sua linguagem, acontece de forma diferenciada, pois depende do nivel de consciência de cada um, da sua inteligência e da sua simbolização lingüistica". 


\subsection{SAÚdE COLETIVA E A PRÁ TICA DE ENFERMAGEM}

A sociedade brasileira, através do Estado $^{3}$ procura garantir os direitos dos cidadãos, dentre os quais destacamos o direito à saúde, reconhecido pela Constituição Federal de 1988.

Visando garantir este direito o Estado realiza ações de saúde traçadas por uma Política de Saúde desenvolvida com a influência de vários setores da sociedade tanto no Poder Legislativo como no Executivo nos niveis federal, estadual e municipal.

Esta "Politica de Saúde" é operacionalizada localmente pelos profissionais de saúde. Sendo parcela do trabalho em saúde, a enfermagem participa na produção dos serviços de saúde.

A enfermagem em saúde coletiva tem como função a prestação de assistência ao individuo sadio ou doente, familia ou comunidade, visando a promoção, proteção, manutenção e recuperação da saúde.

A enfermagem em unidades básicas de saúde é exercida por enfermeiras, auxiliares de enfermagem, e em algumas unidades, por atendentes e visitadores sanitários. Em nosso entendimento, as profissionais

\footnotetext{
${ }^{3}$ Segundo Dallari (1987), Estado é a "ordem jurídica soberana que tem por fim o bem comum de um povo situado em determinado território". Tem a funçāo de coordenar grupos e individuos com vistas a atingir suas metas, impondo a escolha dos meios adequados. Para isso, é necessário levar em consideração o que ele chamou de dualismos fundamentais: a) identificação de necessidades de um povo e as possibilidades de atendimento a elas: b) a conciliação entre as necessidades dos individuos e da coletividade, e c) liberdade e autoridade.
} 


\section{Introduçãa}

de enfermagem ocupam posição privilegiada, pois mantêm contato direto com usuários que demandam aos serviços de saúde e também com outros usuários em potencial, durante todo o período de funcionamento dos serviços, podendo desenvolver suas atividades intra e extra muros das unidades básicas de saúde.

Para o desenvolvimento de suas atividades em unidades básicas de saúde, a enfermeira pode fazer uso de dois modelos assistenciais não excludentes o individual e o coletivo (ALMEIDA 1991; CASTELLANOS 1989), ou clínico e epidemiológico (MERHY, CECÍLIO, NOGUEIRA:1990, NEMES, SILVA JR: 1996).

A assistência individual, com enfoque clínico caracteriza-se por conter dois processos de trabalho: o cuidar e o administrar. O primeiro segue o modelo clínico, tendo como objeto o corpo individual (bio-psico-social), o segundo, tem por objeto de trabalho a própria administração, que tem por finalidade: a organização do processo de trabalho "cuidar" e a coordenação do trabalho da equipe de enfermagem, assim como a educação continuada, que tem por objetivos a formação e a qualificação do pessoal de nível médio, a educação em serviço e a reciclagem do pessoal de enfermagem.

$\mathrm{Na}$ saúde coletiva, área também de interesse deste estudo contempla vários processos de trabalho: educação, vigilância epidemiológica, assistência à família, controle de saúde de populações e/ou grupos de risco, entre outros. 


\section{Tutraducāa}

Conforme estudos realizados por ALMEIDA (1991) e GONÇALVES (1994) em unidades básicas de saúde, identificamos ações do processo "cuidar" na pré consulta, na pós consulta, nos atendimentos de enfermagem, na vacinação, na realização de curativos, coleta de material para exames, na triagem, encaminhamentos e avaliação do estado de saúde do cliente, em atividades de orientação em grupos e na visita domiciliána.

ALMEIDA (1991: 247-251) em estudo sobre o trabalho de enfermagem realizado na rede básica de Ribeirão Preto/SP e que em muitos aspectos pode ser representativo da rede básica de São Paulo verificou que a assistência tem como elemento nuclear a consulta médica, a partir da qual se desdobram outras atividades: coleta de materiais para exames, curativos, administração de medicamentos, orientações e encaminhamentos a serviços de nível secundário, cabendo às enfermeiras a organização da infra-estrutura material, pessoal e funcional para assegurar a assistência; além da coordenação, controle, supervisão de vários setores e da execução de atividades assistenciais mais complexas, além de atuação junto aos usuários que não tendo consulta médica agendada necessitem desse atendimento.

Ainda segundo (ALMEIDA, 1991: 250), os trabalhadores têm uma concepção imediatista da prática assistencial. Ela é tomada como uma ação técnico-cientifica que deixa de ter altos índices de resolubilidade, sendo apontado como razão importante, o pressuposto presente no pessoal de enfermagem de que a clientela é "pobre, ignorante, sem elementos para absorver, aproveitar e consumir com resolubilidade os serviços prestados" o que justificaria a postura paternalista e, portando, 
o desrespeito à autonomia do usuário, desconsiderando-o em seu próprio cuidado.

Aceitando a colocação feita por PELICIONI (1989: 140), de que o staff de enfermeiras é formado por trabalhadores de linha de frente por excelência. e os pacientes despendem com elas mais tempo do que com qualquer outro profissional da equipe de saúde, acreditamos que é fundamental, enquanto compromisso ético e profissional, o respeito ao direito do usuário em participar de decisões que digam respeito a seu cuidado, dando consentimento para a realização de ações cuidativas, após ser devidamente esclarecido. Além disso, no caso de desconhecimento por parte dos usuários, desse seu direito, cabe a ela informá-los.

Devemos ressaltar que o cuidar em enfermagem envolve a responsabilidade e a sensibilidade para com a vontade do usuário. Dada a continuidade de seu contato com ele e seus familiares, muitas vezes a enfermeira é a primeira a perceber situações que implicam problemas éticos, como a violação de direitos do usuánio. No caso especifico do consentimento esclarecido, a enfermeira pode vir a advogar ${ }^{4}$ junto à instituição, no caso de normas internas que possam prejudicar o usuário, ou ainda junto a outros profissionais de saúde pelo cumprimento desse preceito ético.

Diante do exposto até aqui e considerando que:

\footnotetext{
4 Utilizo aqui o termo advogar no sentido de "interceder a favor de" e não no de exercer a profissão de advogado.
} 
- as enfermeiras tomam decisões que dizem respeito aos cuidados de enfermagem dos usuarios;

- o preceito ético do consentimento esclarecido deve ser respeitado pelos enfermeiros em unidades básicas de saúde;

- a prática é fundamental na formação dos profissionais de saúde em todos os niveis;

- o ensino da atitude ética não se dá somente no espaço das aulas teóricas, mas principalmente no espaço da prática cotidiana, e que

- as enfermeiras lotadas em centros de saúde escola, potencialmente participam na formação de profissionais de saúde e no desenvolvimento de pesquisas pretendemos, neste estudo, apreender qual a representação que as enfermeiras lotadas em Centros de Saúde Escola do Estado de São Paulo têm sobre o consentimento esclarecido, e como esta vem sendo operacionalizada no seu cotidiano. 
Oljetivas 


\section{2 - OBJETIVOS E PROPÓSITOS DO ESTUDO}

Diante da problemática da investigação, pretendemos alcançar os seguintes objetivos:

1. Descrever a representação que as enfermeiras têm sobre o consentimento esclarecido na sua prática cotidiana;

2.Verificar como o consentimento esclarecido se operacionaliza na prática das enfermeiras;

3. Analisar esses achados à luz da "teoria dos principios" da Bioética.

Assim procedendo procuraremos contribuir com os seguintes propósitos:

- oferecer subsídios para a introdução de referenciais bioéticos no ensino de enfermagem em saúde coletiva,

- estimular discussões sobre a importância do consentimento esclarecido como instrumento para promover o exercício de cidadania no campo da saúde. 
Métada 


\section{MÉTODO}

\subsection{REFERENCIAL TEÓRICO: PRINCÍPIOS DA BIOÉTICA}

A bioética, surgiu há aproximadamente 30 anos, discutindo de início, "o equilibrio e a preservação da relação do seres humanos com o ecossistema e a própria vida do planeta" (COSTA, GARRAFA e OSELKA, 1998:15), e posteriormente evoluiu para o debate sobre a ética frente à esta evolução cientifica que tem o poder de interferir na vida e na natureza (engenharia genética, aborto e reprodução assistida, por exemplo). Surgiu nos países do primeiro mundo, como produto do estado de bem estar social e da expansão dos direitos humanos. Ela abarca a ética médica mas não se restringe ela, compreende os problemas relacionados a valores que surgem em todas as profissões de saúde, aplica-se às pesquisas biomédicas $e$ às do comportamento, à experimentação em seres vivos e a questões sociais.

Segundo COSTA, GARRAFA e OSELKA (1998:15), sedimentou-se nos meios científicos a partir da publicação do livro de Beauchamp e Childress, "The principles of Bioethics" em 1979, seguindo uma linha que posteriormente foi denominada "principialista".

O paradigma bioético principialista tem por bases o Relatório Belmont, elaborado pela Comissão Nacional para a Proteção dos Seres Humanos em Pesquisa Biomédica e Comportamental em 1978 nos Estados 
Unidos, como reflexo da preocupação social com o controle da pesquisa em seres humanos. Nesse relatório, foram identificados três princípios fundamentais: a beneficência, o respeito pelas pessoas, isto é, a autonomia e a justiça. Segundo PESSINI e BARCHIFONTAINE (1998: 81-98), esse documento "inaugurou um novo estilo ético de abordagem metodológica dos problemas envolvidos na pesquisa com seres humanos". Desde o mesmo, análises passaram a ser feitas a partir destes três princípios, com os procedimentos práticos deles decorrentes, e não mais baseadas em códigos e juramentos. A discussão posteriormente foi aprofundada por Beauchamp e Childress, aplicando esses princípios acrescidos do principio da não maleficência no campo das práticas de saúde.

Esse paradigma bioético dominou o cenário nas décadas de 70 e 80 e atualmente, é quase hegemônico. Segundo COSTA, GARRAFA, OSELKA. (1998), as perspectivas de abordagem bioética além dos principios, são mais de dez, dentre os quais, citamos o contextualismo, o feminismo e o naturalismo.

No presente estudo optamos pela utilização do paradigma principialista pois é o que mais tem sido utilizado pelos bioeticistas na "mediação elou resolução de conflitos morais pertinentes à temática bioética" (COSTA, GARRAFA e OSELKA; 1998:15).

\footnotetext{
“O principialismo é uma teoria moral embasada em principios prima facie e aplicada aos dilemas e conflitos morais que surgiram na área biomédica .... é simultaneamente analítico e pragmático, ..., uma metodologia de análise
} 
moral que analisa, de forma racional e imparcial, os argumentos morais em situaçōes concretas de conflitos de interesses e valores prima facie. visando dirimir, quando possivel, os conflitos pela escolha dos melhores argumentos. ... constitui, ..., uma opçāo metodológica para lidar com situações .... onde existem dilemas morais resultantes de valores legítimos em competição entre si" (SCHRAMM, 1998)

Para BEAUCHAMP e CHILDRESS (1994), os principios devem ser desenvolvidos conceitualmente e conformados normativamerite para conectar com ações-guia concretas e julgamentos práticos.

Para eles, obrigações prima facie indicam uma obrigação que deve ser preenchida a menos que, em um caso particular, entre em conflito com uma obrigação igual ou mais forte. Uma obrigação prima facie é restritiva a menos que seja sobrepujada ou sobrepesada por obrigaçōes morais concorrentes.

Principios, regras e direitos requerem equilibrio e especificação. Principios nos dirigem a certas formas de conduta, mas principios, por si só não resolvem conflitos entre os principios. Enquanto especificação, vincula um considerável desenvolvimento de significado e escopo das normas, o equilibrio consiste na deliberação e julgamento sobre o peso relativo das normas.

Conforme dito anteriormente, a Bioética, segundo BEAUCHAMP e CHILDRESS (1994) tem como princípios básicos a beneficência, a não maleficência, a autonomia e a justiça. 


\subsubsection{Princípio da beneficência}

O principio da beneficência é o mais antigo da ética médica. Diz respeito a se fazer o bem, prevenir e remover o mal ou o dano. O Juramento de Hipócrates e o coloca como uma obrigação profissional - "aplicarei os regimes para o bem dos doentes, segundo meu saber e minha razão". É interessante apontar que o julgamento do que seria para o bem do doente, segundo Hipócrates, é feito pelo profissional, que tem o conhecimento.

O termo beneficência pode significar caridade, filantropia ato ou virtude de fazer o bem, benevolência. Mas, para BEAUCHAMP e CHILDRESS (1994:260) está relacionado ao dever de conferir benefícios, prevenir e remover o mal ou o dano no contexto médico e comportamental, bem como pesar os possiveis benefícios e prejuizos de uma ação.

A obrigação de conferir benefício, prevenir e afastar danos e pesar e equilibrar as possíveis vantagens diante dos custos e possiveis danos de uma ação são centrais na ética biomédica, apesar do princípio da beneficência não abarcar todos os outros princípios. (BEAUCHAMP e CHILDRESS, 1994)

Esses autores (BEAUCHAMP E CHILDRESS, 1994) analisam dois princípios de beneficência que se complementam: a beneficência positiva e a utilidade. A primeira diz respeito a conferir benefícios e a segunda requer que os benefícios e resultados sejam pesados, já que é difícil produzir beneficios ou 
eliminar danos sem criar riscos ou incorrer em custos ${ }^{5}$. Afirmam haver críticas ao princípio da utilidade por parecer permitir que interesses da sociedade ultrapassem os direitos e interesses individuais. Mas devemos lembrar que sendo um dos principios prima facie, não prepondera sobre os outros. Este princípio tarnbém é limitado pelo balanço entre benefícios, riscos e custos e não determina todo o balanço de obrigações.

Tendo, a beneficência, prevalecido durante muitos séculos na prática médica, os profissionais de saúde costumavam apoiar-se apenas em seu julgamento sobre as necessidades das pessoas sob seus cuidados, no que diz respeito ao tratamento e à informação. Entretanto, atualmente encontra-se limitada por quatro questões principais: a) definir o que é o bem do paciente; b) a não aceitação do paternalismo contido na beneficência; c) o surgimento do critério da autonomia; e d) novas dimensões da justiça na área da saúde (PESSINI, BARCHIFONTAINE; 1996).

Contrapondo-se à autonomia do paciente, que apresentamos mais adiante, é provavelmente a que suscita maiores polêmicas em Bioética, mormente quando a discussão versa sobre a capacidade do paciente para decidir, uma vez que o respeito à sua autonomia também pressupōe beneficência.

\footnotetext{
${ }^{5}$ Esse princípio de utilidade difere do Utilitarismo de Mill. Ver (BEAUCHAMP e CHILDRESS 1994: 259-271) e REICH Encyclopedia of Bioethics; 1995
} 


\title{
3.1.1. Paternalismo
}

Paternalismo, segundo Fortes (1998:48)

\begin{abstract}
é "a interferência com a liberdade de um individuo eticamente capacitado para tomada de decisões, mediante uma ação beneficente justificada por razões referentes exclusivamente ao bem estar, às necessidades da pessoa que está sendo coagida, e não por interesses de terceiros, do próprio profissional de saúde ou mesmo de interesses da sociedade" .
\end{abstract}

Segundo CULVER \& GERT (1982 apud FORTES, 1998), para que uma ação seja considerada paternalista é necessário que o profissional acredite que sua ação beneficiará o sujeito e não a ele mesmo ou a terceiros, que sua ação envolve uma violação de regra moral; que o sujeito a quem é dirigida a ação é competente para dar o consentimento e que a ação não tem o consentimento desse sujeito, nem no passado, nem no presente e nem no futuro.

O paternalismo sempre envolve alguma forma de interferência sobre ou recusa em aceitar as preferências pessoais em favor de seu próprio bem. Assim, ações paternalistas podem envolver força, coerção, manipulação da informação, ou mesmo a omissão intencional de informação.

Há posicionamentos éticos conflitantes em relação à utilização do paternalismo nas ações de saúde. Por um lado, há aqueles que o consideram uma usurpação dos direitos do usuário em decidir o que seja melhor para si 
mesmo. Por outro, há aqueles que o consideram necessário na defesa do interesse da pessoa assistida (a restrição da autonomia se justificaria em casos em que a pessoa causasse danos sérios a si mesmo ou que falhasse em assegurar um importante benefício para si mesmo).

Para BEAUCHAMP e CHILDRESS (1994), paternalismo é a desconsideração ou a intervenção intencional sobre as preferências, desejos (conhecidos), ou ações de outra pessoa com a intenção tanto de evitar danos ou beneficiá-la. Diferentemente dos autores anteriormente citados, fazem uma distinção entre o que denominam paternalismo forte e paternalismo fraco. $O$ primeiro, exercido sobre pessoas autônomas, restringe a informação disponivel para a pessoa ou infringe escolhas informadas e voluntárias. O segundo, exercido sobre pessoas consideradas incapazes do ponto de vista jurídico ou incompetentes do ponto se vista moral, protegendo-as, assim de açōes não autônomas.

Afirmam que defensores do paternalismo apresentam os seguintes argumentos que podem justificá-lo: a) os danos a serem prevenidos ou os benefícios providos à pessoa pesam mais que a perda de independência e o senso de invasão causados pela intervenção; b) as condições da pessoa limitam seriamente sua habilidade de fazer uma escolha autônoma; c) a intervençāo é universalmente justificada em circunstâncias similares; e d) o beneficiáno da ação paternalista consentiu, irá consentir, ou ainda iria consentir se tivesse condições racionais (BEAUCHAMP e CHILDRESS, 1994). 


\section{Métada}

Neste estudo, não consideremos esta distinção de paternalismo por consideramos o chamado "paternalismo fraco" como uma ação tanto beneficente como não maleficente, já que a pessoa sobre a qual se toma a decisão é considerada incapaz, e portanto impossibilitada de tomar decisões e de expressar suas preferências.

$\mathrm{Na}$ saúde coletiva, o uso de autoridade na relação profissionalusuáno e nas intervenções de saúde coletiva têm sido muito discutidas. $O$ paternalismo contido na política de saúde é central em questões que digam respeito ao papel do governo na promoção de estilos de vida saudáveis e na prevenção de doenças e agravos auto-infligidos (Reich, 1995)

Sabemos que na Saúde Coletiva a legislação e as ações de saúde podem assumir um caráter paternalista. Segundo BEAUCHAMP (1987:69), o paternalismo para a proteção da saúde coletiva não só é "compativel com valores democráticos .... mas também essencial para defender a vida em comum e para promover o senso de comunidade", promover a saúde e a segurança de grupos mais vulneráveis da sociedade.

Segundo MILL (1952:271) "O único propósito pelo qual a força pode ser corretamente utilizada sobre qualquer membro de uma comunidade civilizada, contra a sua vontade, é prevenir danos a outros. Seu próprio bem, tanto físico como moral não é garantia suficiente". De acordo com BEAUCHAMP 
(1987), o Estado não deve requerer legitimamente que o individuo cuide de sua própria segurança. As chamadas obrigações consigo mesmo não são socialmente obrigatórias, a não ser que sejam ao mesmo tempo deveres para com outros.

\subsubsection{O Principio da não Maleficência}

O Princípio da não maleficência é colocado juntamente com a beneficência no juramento hipocrático: "aplicarei os regimes .... nunca para prejudicar ou fazer o mal a quem quer que seja". O conceito de não maleficência está relacionado à máxima primum non nocere - antes de tudo, não causar dano.

A não maleficência freqüentemente é explicada pelo termo "dano", cuja definição pode ser tão ampla que inclua prejuizo à reputação, propriedade e liberdade, ou mais restrita, distinguindo como danos físicos e mentais.

Os danos físicos incluem-se a dor, a incapacidade e a morte. Assim, o princípio da não maleficência acaba por levar a regras morais especificas como por exemplo, não matar e não causar dor. Entretanto, muitas vezes tornase necessário produzir algum prejuizo para prevenir outro pior, por exemplo, causar dor para evitar a morte (uma cirurgia por exemplo), prejudicar uma pessoa para proteger outra(s), o que por vezes leva ao debate sobre a 
relatividade do que se está protegendo pelo princípio de não maleficência (BEAUCHAMP e CHILDRESS, 1983:109-110).

O dever de não causar mal inclui não apenas os danos reais, mas também os riscos potenciais. Os riscos variam de acordo com as probabilidades e os montantes de dano. Além disso, os profissionais não apenas tomam riscos para si mesmos, mas também impõem riscos a outros.

Paralelamente, este princípio requer que os profissionais sejam cuidadosos e atenciosos, já que nem todos os danos ou riscos de dano são produzidos intencionalmente. Deve-se diferenciar não maleficência de negligência, que segundo BEAUCHAMP e CHILDRESS (1994) é um desvio do padrão de cuidado devido a outros, conduta abaixo de um padrão de cuidado devido estabelecido por lei ou moralidade para proteger terceiros da imposição imprudente, irracional ou até mesmo intencional de riscos. Para eles o termo se aplica a vánas formas de falha em se atender obrigações, incluindo falha em proteger a outros contra risco de dano. Esse padrão de cuidado devido inclui conhecimento, habilidades e diligência (BEAUCHAMP e CHILDRESS, 1983).

\subsubsection{Princípio da autonomia}

O termo autonomia tem sua origem nas palavras gregos autos (próprio, por si mesmo) e nomos (regra, convenção, governo ou lei), significa 


\section{Métada}

autogoverno, referindo-se, em nivel individual, ao poder da pessoa tomar decisōes que afetem sua vida, sua integridade físico-psiquica, suas relaçōes sociais. Indica ainda a "condução de uma pessoa ou coletividade, capaz de determinar por ela mesma a lei à qual se submeter" (SEGRE, SILVA e SCHRAMM, 1998).

Para Kant, segundo COHEN e MARCOLINO (1995) e HOLM (1998), a autonomia é um conceito central, em que a liberdade, é mais do que liberdade de constrangimentos externos. Para ele, o agente da ação deve escolher suas açōes livremente, baseado em principios morais escolhidos da mesma forma. 0 respeito pela autonomia reconhece que todas as pessoas têm um incondicional valor, cada qual tendo a capacidade para determinar seu próprio destino traçado pela razão, balizado pelas categorias imperativas

Já Stuart Mill (1952) apresenta uma maior preocupação com a liberdade individual. Para ele, o controle social sobre as açōes individuais é legitimado somente se for necessário prevenir dano a terceiros ou à coletividade, sendo que as pessoas deveriam ter permissāo para desenvolver suas potencialidades de acordo com suas próprias convicçōes (BEAUCHAMP e CHILDRESS, 1994; COHEN e MARCOLINO, 1995; MUÑOZ e FORTES, 1998; ENCICLOPEDIA OF BIOETHICS, 1998).

Do ponto de vista de Mill, não deve haver influência externa à pessoa na expressão da autonomia do individuo, e no de Kant, o dever imperativo 
categórico ("trate os outros e cada um nunca como meramente um meio, mas sempre e ao mesmo tempo como um fim nele mesmo" - Encyclopedia of Bioethics, 1998) estabelece uma moral imperativa para moldar certas atitudes de respeito ao individuo.

Para BEAUCHAMP e CHILDRESS (1989), a autonomia diz respeito

“à capacidade de autogoverno, uma qualidade inerente dos seres racionais que lhes permite escolher e atuar de forma razoável, baseados sobre uma apreciação pessoal das possibilidades futuras avaliadas em funçăo de seu próprio sistema de valores. Deste ponto de vista, a autonomia é uma capacidade que emana da capacidade dos seres humanos de pensar, sentir e emitir juizos sobre o que consideram bom."

Segundo BEAUCHAMP e CHILDRESS (1989: 71), COHEN e MARCOLINO (1995); e MUÑOZ e FORTES (1998:58), entre outros, para se respeitar uma pessoa autônoma, é necessário, primeiramente, reconhecer que as pessoas tèm capacidades e perspectivas próprias, incluindo seu direito de ter pontos de vista próprios, fazer escolhas baseadas em valores, aspiraçōes e crenças pessoais, mesmo que divirjam daqueles mais aceitos pela sociedade ou pelos profissionais da saúde. Além disso pressupōe-se a aceitação do pluralismo ético-social caracteristico de nosso tempo, isto é, ... o respeito à pessoa autônoma envolve mais do que ter essa atitude, implica em tratar as pessoas de forma a permitir ou tomá-las aptas a agir autonomamente. 
O exercicio da autonomia está relacionado à possibilidade de se optar e está condicionada à existência de competência para fazê-lo, além do reconhecimento de sua existência pelo outro e da existência de elementos de opção.

Escolhas autônomas devem ser feitas com intencionalidade, entendimento das opções existentes e livres de controle ou constrangimento impostos por terceiros (FADEN, BEAUCHAMP, KING: 1986). Igreja, Estado e outros grupos que influenciam as decisōes das pessoas podem por vezes ser considerados incompativeis com o exercicio da autonomia; entretanto, as pessoas também exercem sua autonomia quando escolhem se submeter às normas de uma instituição ou à tradição.

Já MILLER (1981 citado na ENCICLOPEDIA OF BIOETHICS, 1998), vê a autonomia de ação e decisão em quatro niveis enquanto:

"(1) ação livre (meios e independência); (2) autenticidade ( a decisão é consistente com aquilo que se sabe serem seus valores, preferências e planos); (3) deliberação efetiva (racionalidade); e (4) reflexāo moral (deliberação sobre seus valores, preferências e planos). A decisão de um paciente pode ser autônoma em um ou mais niveis, mas não em todos".

Para que uma pessoa se torne autônoma, é necessário que alguns aspectos biológicos, psiquicos e socioculturais sejam desenvolvidos. Assim, algumas pessoas, de forma transitória ou permanente, têm sua autonomia 
reduzida: as crianças, os deficientes mentais, pessoas em estado de agudização de transtornos mentais, individuos sob intoxicação exógena, em estado de coma, etc. Desordens emocionais, mentais e mesmo alterações físicas podem reduzir a autonomia do individuo, fazendo com que decisões sejam tomadas por terceiros, familiares ou mesmo pelos profissionais de saúde. (MUÑOZ e FORTES, 1998: 59).

Mas essa competência deve ser avaliada pelo profissional de saúde que assiste ao individuo, o que é uma tarefa complexa do ponto de vista ético. O julgamento da competência ou incompetência de cada pessoa deve se dingir a cada situação em particular inclusive nos casos em que o indivíduo é considerado legalmente incompetente.

Em uma sociedade de classes como a nossa, os grupos sociais mais desfavorecidos e, portanto com menor acesso a bens e serviços, são mais afetados no desenvolvimento de sua autonomia, suas alternativas de escolha são limitadas e condicionadas pelo fator sócio-econômico. Entretanto, isso não implica a determinação de que não podem tomar decisões autônomas.

Na vida em sociedade, a autonomia individual nunca é absoluta, mas sempre relativa. Na área da saúde, existem limitações à autonomia, limitações estas relacionadas aos princípios de justiça, beneficência, e não maleficência isto é, quando uma decisão autônoma põe em risco a saúde pública ou de terceiros (PELLEGRINO, 1990; COHEN \& MARCOLINO, 1995), quando há 
provas de conflito de interesses, quando as decisões autônomas ferirem a integridade do profissional de saúde (por exemplo, se a escolha do cliente vai contra um princípio moral do profissional) e finalmente, quando o interesse predominante na autonomia leva ao individualismo, a um "privatismo moral", esquecendo a comunidade.

A autonomia e o consentimento esclarecido assumiram posição de destaque na ética em saúde a partir da década de 70 , como conseqüência de muitos acontecimentos, tais como o Código de Nuremberg ${ }^{6}$; o avanço mundial da democracia participativa, a desconfiança da autoridade e da competência técnica em particular; a expansão da educação pública; o movimento em prol dos direitos civis; a introdução do direito, da economia e do comércio nas decisões médicas. (PELLEGRINO, 1990).

\subsubsection{Consentimento Esclarecido}

O termo consentimento esclarecido foi elaborado em vários contextos: na ética, no direito e na medicina. Pode ter dois sentidos. O primeiro diz respeito à doutrina ética, baseada no valor da autonomia, que garante ao paciente seu direito de autodeterminação quando decisões relativas à saúde devam ser tomadas; e refere-se também a um processo interpessoal em que

\footnotetext{
${ }^{6} \mathrm{O}$ Julgamento de Nuremberg trouxe a público denúncia sobre o uso de seres humanos em pesquisas durante a II Grande Guerra e teve como conseqüencia o Código de Nuremberg que procurou regular eticamente a questão, introduzindo a obrigatoriedade de obtenção do consentimento voluntário.
} 
médicos e outros profissionais de saúde interagem com o paciente com a finalidade de selecionar um cuidado apropriado à saúde. O segundo, refere-se a regras legais, que regulam o comportamento dos profissionais de saúde na sua interação com clientes, ou ainda a regras institucionais para a obtenção do consentimento válido de clientes em potencial, prevendo penalidades legais quando da sua não obtenção; diz respeito às regras institucionais para a obtenção do consentimento. Uma autorização é considerada efetiva se obtida através de procedimentos que satisfaçam as regras que regem práticas institucionais especificas de consentimento. Qualquer consentimento é considerado informado ${ }^{7}$ se satisfizer as regras operativas que governam a prática, portanto, não é resultado de autorização autōnoma, pois deriva de obrigação imposta pela justiça. (APPELBAUM, LIDZ, MEISEL: 1987; BEAUCHAMP e CHILDRESS, 1989).

\section{Para FORTES (1996 a),}

"obter consentimento do individuo para procedimentos a serem praticados sobre seu organismo é fenômeno histórico-social, deriva do evoluir da conceituação teórica e da conquista dos direitos de cidadania, assim como da idéia de que todos sāo iguais e livres, base dos valores da cultura ocidental dos últimos séculos".

\footnotetext{
${ }^{7}$ Utilizamos aqui propositadamente o termo informado pois privilegia normas que prevèm o fornecimento de informaçōes em detrimento ao seu aclareamento.
} 
O consentimento esclarecido deriva do princípio da autonomia dos individuos, principio fundamental que deve guiar as açōes no campo da saúde.

O consentimento esclarecido, afora os requisitos legais, age no sentido de promover o cuidado dos pacientes através do aumento do vínculo de confiança, pela facilitação da autonomia através da provisão de escolha, e pela crescente participação do paciente em seu próprio cuidado. (BEAUCHAMP, FADEN, 1995).

A literatura geralmente analisa o consentimento esclarecido em termos dos seguintes elementos: a informação, a compreensão, a intencionalidade, a competência e o consentimento, que por si definem o consentimento esclarecido tanto no contexto médico como legal. (BEAUCHAMP e CHILDRESS, 1994; MORENO, CAPLAN, WOLPE, 1998)

A competência para consentir ou tomar decisões é um pré requisito para o agir autonomamente. Entretanto, não existe padrão de competência, ela varia de acordo com o contexto e com o tipo de tarefa a ser desenvolvida. Por exemplo, decidir sobre que roupa usar ou sobre o conteúdo de uma disciplina de pós graduação que se vai ministrar exigem competências diferentes. Por outro lado, as pessoas podem ser mais ou menos competentes conforme tenham um nivel de habilidades adquiridas segundo as suas possibilidades econômicas, culturais e sociais. 
Padrōes para a determinação da competência geralmente consideram aspectos relacionados a habilidades e capacidades mentais. Critérios de eficiência, exeqüibilidade e aceitação social na determinação de uma autorização válida.

Para que o consentimento seja esclarecido, informação é condição básica, e a forma como ela é revelada pode afetar a tomada de decisão. Os profissionais devem revelar: "os fatos ou descrições que a pessoa considere essenciais para que ela possa consentir ou recusar a intervenção ou a pesquisa proposta; informaçōes que 0 profissional acreditem ser fundamentais; as recomendaçōes profissionais; o propósito de se obter o consentimento; e a natureza e limites do consentimento como um ato de autorização" (BEAUCHAMP e CHILDRESS, 1994:147)

A participação da informação inclui os padrōes da prática profissional, isto é, da pessoa razoável e o subjetivo. O primeiro é determinado pelas regras habituais e práticas tradicionais da comunidade profissional, o indivíduo deve revelar aquilo que um colega consciencioso e razoável teria feito em iguais circunstâncias. Assim, se estabelece a quantidade e tipo de informação a serem oferecidas. O segundo, por uma hipotética pessoa razoável, que pudesse configurar um modelo padronizado de paciente de uma determinada cultura. A pertinência da informação é medida pela significância que ela teria para a tomada de decisão de tal pessoa. Neste padrão entretanto, o profissional continua decidindo o que deve ou não ser revelado. Por fim, o padrão subjetivo 
ou orientado ao paciente é determinado pela necessidade de informação de cada individuo especificamente, pois elas diferem de acordo com suas crenças, problemas de saúde, história familiar (BEAUCHAMP \& CHILDDRESS, 1994, FORTES, 1994), sua classe social e suas condiçōes de existência.

Para dar um consentimento esclarecido, o paciente/usuário deve receber as informações necessárias: sobre a natureza de seu problema, seu tratamento, e cuidados, suas conseqüências, possiveis riscos, bem como a existência de outros tipos de tratamentos e cuidados alternativos. Estas informaçōes devem ser comunicadas em uma linguagem acessivel e compreensível para o paciente/usuário. Além disso, o consentimento deve ser dado sem constrangimerito por parte de outra pessoa ou mesmo instituição (DURANT, 1995).

Para que decisōes sejam tomadas é necessário que as informações sejam bem entendidas. Assim, deve-se dar especial atenção à forma de abordagem, à linguagem utilizada e à quantidade de informação oferecida.

Quanto á intencionalidade na tomada de decisão, centra-se na independência da influência de manipulação ou coerção por parte de outras pessoas. Entretanto devemos lembrar que existem condições em que a intencionalidade pode estar diminuida ou sem validade tais como ter uma doença debilitante, desordens psiquiátricas ou estar em estado alterado pela drogadição. 
Atualmente no Brasil, seguindo a tendência mundial, a pressão sofrida pelos profissionais e seus conselhos pela melhoria da qualidade da assistência, a organização da sociedade pressionando pelo respeito a seus direitos e pela melhoria da qualidade da assistência através de, por exemplo, as instâncias de participação popular no sistema de saúde: Conselhos Municipais, Estaduais e Nacional de Saúde; Conselhos Gestores; as associaçōes de doentes; os sindicatos; e o PROCON, o respeito ao consentimento esclarecido foi acrescido ao Código de Ética Médica em 1988, no de Odontologia em 1991 e no de Enfermagem em 1993. Ao mesmo tempo observa-se um aumento na midia de assuntos relacionados aos direitos dos pacientes, entre eles, o consentimento esclarecido. Por exemplo, a reportagem sobre a modificação do termo de responsabilidade quando da internação no Hospital das Clínicas da Faculdade de Medicina da Universidade de São Paulo (Folha de São Paulo, 6 de outubro de 1996), além da publicação de material elaborado pelo Fórum de Patologia do Estado de São Paulo ${ }^{8}$., que congrega representantes de diversas associações de usuários dos serviços de saúde (como por exemplo a Associação do Renais Crônicos) e a Secretaria de Estado da Saúde de São Paulo. Este material foi elaborado a partir de discussões dos integrantes desse

\footnotetext{
${ }^{8}$ Săo Paulo (s/d). Os direitos do paciente. Foram elencados 35 direitos, sendo que 6 dizem respeito ao consentimento esclarecido.
} 
fórum com técnicos da Secretaria e docentes da área de ética, no sentido de informar os usuários do sistema de saúde sobre seus direitos e instrumentalizálos na luta por esses direitos

Mas existem alguns obstáculos à utilização do consentimento esclarecido, como veremos a seguir (MORENO, CAPLAN, WOLPE, 1998). Dentre as dificuldades em se obter o consentimento esclarecido, são fundamentais os problemas de comunicação técnica (por exemplo, qual o significado de $10 \%$ de chance de complicações para o técnico e para o usuário) e o valor agregado à informação, principalmente a pessoas submetias a stress. Fatores como nível educacional, cultura também interferem nessa comunicação.

Outro obstáculo é a falta de conhecimento técnico por parte do usuário. Informaçōes sobre um procedimento, seus riscos, conseqüências e benefícios, mesmo quando apresentadas de forma inteligivel podem não ser suficientes para produzir um consentimento realmente esclarecido.

O terceiro diz respeito ao estado emocional do paciente ou sua habilidade em pensar ou raciocinar claramente. Uma relativa inabilidade de participar racionalmente do processo do consentimento esclarecido é ocorrência comum na pessoa seriamente doente. Um sintoma como a dor pode ser tão significativa para o paciente que ele fará ou se submeterá a qualquer procedimento para se livrar dessa aflição. Da mesma forma, a experiência 
anterior com uma dada situação pode influenciá-lo de tal forma que ele pode se tornar inapto para compreender a informação que está recebendo.

ARNOLD e LIDZ (1998) informam que vários estudos foram realizados e demonstram que os pacientes se lembram apenas uma pequena porcentagem das informações que os profissionais lhes oferecem e que às vezes eles não tomam boas decisōes quando estão doentes. Ressaltam ainda que a sua dificuldade em compreender importantes aspectos da decisão médica não significa que os profissionais tomarão decisōes melhores por eles. Afirmam que tanto o profissional quanto o usuário contribuem para a tomada de decisão o paciente traz seu conhecimento de sua situação pessoal, metas e valores e os profissionais de saúde trazem sua experiência sobre a natureza do problema e da tecnologia que pode ser utilizada no alcance das metas do paciente.

Por outro lado, não existe obrigatoriedade do usuário participar das decisões sobre sua saúde se ele não o desejar. Entretanto, a menos que o profissional de saúde pergunte, não existe possibilidade de saber se ele deseja participar ou não. Muitas vezes, para os usuários, mormente os mais pobres, o profissional de saúde "sabe o que é melhor". Muitos desses pacientes perguntam menos e os profissionais de saúde acabam achando que eles não querem muitas informações. Entretanto, eles foram socializados de forma diferente na interaçāo com profissionais de saúde (ARNOLD, LIDZ: 1998). 


\section{Métado}

Os profissionais de saúde também podem vir a omitir informações intencionalmente por acreditar que a informação poderia trazer danos psicológicos e dessa forma contrariar o princípio da não maleficência. Muitos profissionais, entretanto super estimam o potencial de risco psicológico e negligenciam os efeitos positivos da informação como um todo (FADEN, BEAUCHAMP, KING, 1986)

O consentimento requer que o profissional dedique um certo tempo para ajudar os usuários a compreenderem sua doença e trabalhar suas reações emocionais à informações stressantes; discutir os preconceitos de cada parte, clarificar as metas do cuidado, decidir por um plano de tratamento e elucidar questões sobre diagnóstico e tratamento. No Brasil, mormente nos serviços públicos, o tempo para atendimento é escasso. Por exemplo, calcula-se que cerca de 15 minutos são suficientes para a realização de uma consulta médica. Como os serviços são remunerados pela produção (de consultas médicas, atendimentos por outros profissionais de nível superior e de nivel médio), o tempo disponivel para a obtenção do consentimento esclarecido nem sempre é suficiente. 


\subsubsection{Princípio da Justiça}

O princípio da justiça formal coloca que os semelhantes devem ser tratados da mesma forma e que os não semelhantes devem ser tratados de forma diferenciada (não semelhante). É formal, pois, apesar da colocação anterior, não define em que situaçōes os iguais devem ser tratados da mesma forma, nem oferece critérios para a determinação dessa igualdade entre uma ou mais pessoas (BEAUCHAMP e CHILDRESS, 1989:259).

As teorias sistematizadas de justiça, foram desenvolvidas ao longo da história, procurando determinar como bens e serviços devem ser distribuídos. As teorias igualitárias dão ênfase ao acesso igualitário a todos os bens; as teorias liberais enfatizam direitos à liberdade social econômica e as teorias utilitaristas, uma mistura de critérios de forma que a utilidade pública é maximizada. (BEAUCHAMP \& CHILDRESS, 1989:265).

No periodo compreendido entre o século VI a.C. até o século XVII, vigorou a teoria de que a justiça era uma propriedade natural das coisas, imutável, em que tudo tem seu lugar no mundo cósmico e nas relações humanas: os individuos inferiores deveriam permanentemente obedecer aos governantes. A cultura grega colocava claramente a superioridade do bem comum sobre o individual. Aristóteles considerava a pólis, por natureza, anterior ao indivíduo "porque o todo é necessariamente anterior à parte e por ser somente ela (polis), auto-suficiente em si mesman. Essa visão ganha contornos 
de doutrina religiosa com São Tomás de Aquino: "o mundo sobrenatural unido ao natural em plena harmonia, tudo regido por uma lei imutável". (SIQUEIRA, 1998:72-3)

Assim, a justiça seguiria uma proporcionalidade natural. A atenção médica prestada era proporcional à categoria social, que era definida por um principio metafísico, e os individuos deveria obedecer passivamente às orientaçōes médicas. (SIQUEIRA, 1998:72-3)

No final do século XVII, evolui-se para uma definição de justiça como um bem decidido em termos de um contrato social. Para John Locke, a justiça seria construida sobre um contrato social que obrigatoriamente emanava do exercicio da liberdade individual, cabendo ao Estado apenas permitir o exercício dos direitos naturais de cada cidadão (direito à vida, saúde, liberdade e propriedade). Assim, os direitos individuais prevaleceriam sobre o Estado e a plena liberdade de contrato substituiría a ordem natural. (SIQUEIRA, 1998:73-5)

Em relação à saúde, estabeleceu-se os princípios da medicina liberal e as regras de relacionamento médico paciente, afastando o Estado de qualquer tipo de intervenção. Como conseqüência, instituiu-se no século XIX, três tipos diferenciados de assistência médica: as famílias ricas que pagavam os honorários arbitrados pelos médicos; uma parcela da população, se utilizava de seguro privado e finalmente, para a maioria das pessoas pobres que não tinham acesso aos serviços de saúde, cabia a assistência prestada nas Santas Casas 
de Misericórdia. Sua situação de penúria acabava retirando delas o direito a qualquer reivindicação sobre justiça e as levava a uma obediência extrema e cheia de gratidão. (SIQUEIRA, 1998:73-5)

Finalmente, Karl Marx e Friedrich Engels propōe o regime socialista como o único caminho para a construção de uma sociedade realmente igualitária e justa. Para Marx, “a sociedade humana deveria aspirar um Estado no qual fossem abolidas a personalidade, a independência e a liberdade burguesa" (SIQUEIRA, 1998:75-77).

As teorias utilitaristas dizem que o princípio da justiça não é independente do princípio da utilidade. Na distribuição de cuidados de saúde, vêem a justiça envolvida com negociação e balanços. $\dot{E}$ necessário equilibrar benefícios públicos e privados, custo benefício previsto, a probabilidade de falha, a magnitude dos riscos, etc. (BEAUCHAMP e CHILDRESS, 1994).

As teorias liberais, aceitam as regras da livre lei de mercado, os assuntos não são matéria de planejamento social, mas exclusivamente de escolha pessoal e qualquer intervenção social no mercado em nome da justiça perverteria a própria justiça ao colocar constrangimentos à liberdade individual. (BEAUCHAMP e CHILDRESS, 1994)

As teorias igualitárias de justiça propõe que as pessoas deveriam receber um distribuição igualitária de pelo menos alguns bens e serviços. Em sua forma radical, argumentam que a distribuição de benefícios e ônus em uma 
sociedade é justa na medida em que sejam iguais, e que desvios da igualdade absoluta na distribuição é injusta. Para alguns, apenas ser membro da espécie humana não dá o direito à divisão igualitária de todos os benefícios sociais e essa deserção justifica algumas diferenças na distribuição. John Rawls, um deontologista , diz que um acordo social é um esforço comunitário para que o bem seja disseminado para todos os que são parte de uma sociedade. Para ele, desigualdades de nascimento, dotes naturais, e circunstância histórica estão em desvantagem natural, assim, as pessoas em uma sociedade cooperativa, deveriam tornar mais iguais as situações desiguais desses individuos (BEAUCHAMP e CHILDRESS, 1994). 


\subsection{PROCEDIMENTOS METODOLÓGICOS}

Para apreender as formas pelas quais as enfermeiras de Centro de Saúde Escola representam a sua relação assistencial junto a usuários em saúde coletiva, no tocante ao consentimento esclarecido, optamos pela utilização de uma abordagem metodológica qualitativa que, segundo MINAYO permite:

"incorporar a questão do significado e da intencionalidade como inerentes aos atos, às relaçōes e às estruturas sociais, sendo essas últimas tomadas tanto no seu advento quanto na sua transformação, como construçōes humanas significativas" (1993-10).

Segundo MINAYO (1993:158),

"Representações sociais ... são definidas como categorias de pensamento, da ação e de sentimento que expressam a realidade, explicam-na, justificando-a ou questionando-a".

A mesma autora (MINAYO 1993:161) referindo se a Max Weber, diz que para ele, a vida social, que consiste na conduta cotidiana dos indivíduos, é carregada de significação cultural que é dada tanto pela base material como pelas idéias (ou representações sociais), dentro de uma adequação, em que ambas se condicionam mutuamente. Para ela, as representaçōes são juízo de valor que os individuos dotados de vontade possuem.

Para Schutz, citado por MINAYO (1993:164) "tanto o conhecimento cientifico como o senso comum envolvem conjuntos de abstrações, formalizações e generalizações. Esses conjuntos são construídos, são fatos 
interpretados, a partir do mundo do dia-a-dia". Assim, a vida cotidiana é dotada de significados e traz consigo estruturas de relevância para os grupos sociais. A compreensão do mundo se dá a partir de um estoque de experiências de outros (antepassados, contemporâneos, etc.). O mundo do dia-a-dia é entendido como uma teia de significados, instituído pelas ações humanas e passivel de ser captado e interpretado.

As experiências de qualquer ator social dependem de sua história de vida. Assim, cada um deles tem um conhecimento de sua experiência e atribui relevância a determinados temas, aspectos ou situações, de acordo com sua própria história anterior. Daí a importância dada ao senso comum, "porque através dele o ator social faz sua própria definição de situação. Isto é, não só age como atribui significados portadores de relevância à sua ação, de acordo com sua história de vida, seu estoque de conhecimentos ....". Esse estoque se forma através de tipificações do mundo do senso comum. Isso permite a identificação de grupos, a estruturação comum de relevâncias e possibilidade de compreensão de um modo de vida especifico de determinado grupo. (MINAYO, 1993:165)

\section{Campo de estudo e sujeitos da pesquisa}

Para a realização do estudo, selecionamos quatro Centros de Saúde Escola localizados na cidade de São Paulo e um quinto localizado em cidade de médio porte do interior do Estado. Entretanto, durante os contatos prévios mantidos com essas unidades para a coleta de dados, verificamos 
que uma delas encontrava-se em fase de mudança para uma Unidade Básica de Saúde (UBS) da Secretana de Estado da Saúde, onde, incorporando os recursos existentes (físicos, humanos e materiais), passaria a atender sua demanda original, além daquela que já fazia uso da UBS. Esta mudança exigiu na época, alteraçōes significativas, desde a acomodação fisica do mobiliário e prontuários à adaptação por parte do pessoal à nova estrutura administrativa, a definição de funçōes, de atividades e programas de saúde, bem como dos usuários à nova rotina, o que nos levou a optar por sua exclusão do universo da pesquisa.

Sendo o universo de enfermeiras lotadas nos quatro CSEs pequena, a população a que este trabalho se refere é de todas as enfermeiras lotadas nesses serviços, totalizando quatorze enfermeiras.

\section{As estratégias de coleta e análise de dados}

Visando caracterizar os CSEs em que as enfermeiras desenvolvem suas atividades, no que diz respeito ao vínculo técnico e admiristrativo, sua história, programas e modelo assistencial adotados, cursos e tipo de participação na formação de profissionais de saúde, realizamos entrevistas com as enfermeiras chefe e alguns diretores das

unidades seguindo o roteiro que se encontra em anexo (Anexo 1) e que foi preenchido à medida que as respostas foram sendo obtidas. 
Para conhecer as representações dos sujeitos desta pesquisa acerca do consentimento esclarecido no cotidiano de seu trabalho, optamos pela utilização da técnica de entrevista.

Para vários autores (LUDKE, ANDRÉ, 1986:33-9, HAGETTE, 1995:86-91 e MINAYO, 1993:107-9), ela é um processo de interação social entre duas pessoas que se realiza por iniciativa do entrevistador, que possibilita a captação imediata de informações objetivas e subjetivas do entrevistado, tendo como escopo um determinado objeto de pesquisa.

Segundo MINAYO (1995), as representações se manifestam em palavras, sentimentos e condutas, mas têm na linguagem, enquanto forma de conhecimento e de interação social, a sua mediação privilegiada, apesar de traduzir um saber fragmentário e de se limitar a alguns aspectos da experiência existencial, freqüentemente contraditória. "Fruto da vivência das contradições que permeiam o dia a dia dos grupos sociais e sua expressão marca o entendimento deles com seus pares, seus contrários e com as instituiçōes. Na verdade, a realidade vivida é também representada e através dela os atores sociais se movem, constróem sua vida e explicam-na mediante seu estoque de conhecimentos".

Por outro lado a fala pode ser reveladora de "condições estruturais, de sistemas de valores, normas e símbolos e ao mesmo tempo ter a magia de transmitir através de um porta-voz as representaçōes de grupos determinados em condiçōes históricas, sócio-econômicas e culturais especificas" (MINAYO, 1993:109-10). 
Considerando que a entrevista realiza-se numa situação de interação pesquisador-pesquisado, deve-se reconhecer de que o seu produto é afetado pelas condições de sua produção. Em primeiro lugar, porque se dá por iniciativa do pesquisador, que elabora um projeto baseado em objetivos Ihe são próprios. $\dot{E}$ ele quem dirige e controla a entrevista, concede a palavra, etc., o que determina uma situação de desequilibrio (MINAYO, 1993).

Esta situação não implica o comprometimento da objetividade no processo de pesquisa de campo. Deve-se compreendê-la e assumí-la como condição de aprofundamento e conseqüência da relação interativa (MINAYO, 1993).

Paralelamente, considerando que, a "entrevista tem que ser incorporada a seu contexto e vir acompanhada, complementada ou como parte da observação participante .... desta forma captam-se as relações, as práticas, os gestos e cumplicidades e a fala informal sobre o cotidiano". Minayo (1993:120).

Observação participante, segundo Schwartz, Schwartz, citados por MINAYO (1993: 134-156) é definido como

\footnotetext{
"um processo pelo qual mantém-se a presença do observador numa situação social, com a finalidade de realizar uma investigação científica. O observador está em relação face a face com os observados e, ao participar da vida deles, no seu cenário cultural, colhe dados. Assim, o observador é parte do contexto sob observação, ao mesmo tempo modificando e sendo modificado por esse contexto".
} 
Optamos para a realização deste estudo pela observação participante que para Gold “é empregada freqüentemente como estratégia complementar ao uso de entrevistas, nas relaçōes com os 'atores'. Trata-se de uma observação quase formal, em curto espaço de tempo e suas limitações advêm desse contato bastante superficial". (citado por MINAYO 1993: 142)

As observações foram realizadas em sua maioria após as entrevistas e centraram-se em atividades assistenciais diretas e administrativas, seguindo o roteiro em anexo (Anexo 3).

Para a realizaçāo das entrevistas, seguimos o roteiro que se encontra no Anexo 2. Este roteiro foi dividido em quatro partes: uma de identificação, em que foram levantadas informações sobre idade, cargo e função ocupados, a segunda por informaçōes sobre a formação escolar, a terceira, sobre sua trajetória profissional até o ingresso no CSE e finalmente, a quarta, em que se obteve informaçōes sobre atividades desenvolvidas no serviço e sua relaçāo com usuários nas atividades assistenciais.

As questōes das duas primeiras partes da entrevista foram elaboradas com o intuito de traçar um perfil dos sujeitos. A terceira, para obter informações sobre sua experiência profissional prévia e as atividades desenvolvida pelas enfermeiras no CSE naquele momento, pois acreditamos que poderiam trazer informações importantes que subsidiariam o entendimento sobre a forma como esses agentes se relacionam com os usuários. Finalmente. a quarta, em que partindo da atividade realizada no dia 
anterior à entrevista, questionávamos se havia tomado decisões que diziam respeito ao cuidado a usuários, como essas decisōes foram tomadas, o que foi levado em consideração, além de outras questões pertinentes objetivando a obtenção de informações sobre a relação enfermeira-usuário, especificamente no que diz respeito ao consentimento esclarecido.

Devemos esclarecer, que durante o pré teste dos instrumentos, verificamos que algumas enfermeiras desconheciam o termo "consentimento esclarecido", o que nos levou a inserir a questão em que indagávamos diretamente sobre ele ao final das entrevistas.

De todos os CSE apenas um solicitou a apresentação do projeto de pesquisa resumido, para ser submetido à comissão de ética médica, já que não contava com uma comissão de pesquisa na unidade. Conforme nos informaram, esta medida foi tomada devido ao grande número de solicitações para a realização de pesquisas, e a necessidade de proteger os direitos de seus profissionais e de sua clientela, e ainda, garantir o andamento das atividades rotineiras da unidade.

Os dados foram coletados no periodo de fevereiro a junho de 1998, a partir das seguintes fontes: documentos, manuais, normas, rotinas, etc; entrevistas a 13 enfermeiras e 2 diretores das unidades; e observação das atividades desenvolvidas pelas enfermeiras em 7 periodos.

Todas as entrevistas foram precedidas de contato pessoal no qual foi explanada, para diretores e enfermeiras dos serviços selecionados, a natureza do estudo, visando obter consentimento para a realização do 
estudo, bem como para o acesso a documentos dos serviços (manuais, declarações, formulários de consentimento, etc), e para a realização das entrevistas, sua gravação, transcrição e uso das informaçōes obtidas, garantindo, o anonimato. Foi solicitada também autorização para a realização de observação de suas atividades por pelo menos um período, sendo que a cada atividade assistencial observada, solicitamos o consentimento verbal dos usuários envolvidos no cuidado, ou na atividade de grupo.

As entrevistas foram conduzidas pela própria pesquisadora, através de questōes orientadoras (Anexo 2).

Somente uma entrevista, foi realizada em no local de trabalho da pesquisadora, a pedido da enfermeira.

As atividades observadas foram as de vacinação, visita domiciliária, grupos de gestante e aleitamento, pós consulta no setores de Tisiologia e Vigilància Epidemiológica, outras atividades no setor de Vigilància Epidemiológica, orientação para exame de eletrocardiograma e reunião de avaliação de visita de supervisão de posto credenciado de vacina.

Durante a realização da coleta, por motivo de licença maternidade, foi necessário adiar uma das entrevistas como as informações obtidas junto a treze enfermeiras mostrou-se suficiente para a realização do estudo, optamos pela exclusão dessa entrevista.

As dificuldades enfrentadas na coleta de informações se relacionaram à gravação das entrevistas. 
Durante a realização das entrevistas houve falha na gravação de uma das entrevistas, com perda de cerca de 20 minutos iniciais, o que nos obrigou a retornar à unidade para coletar as informações sobre a "história " profissional da entrevistada.

Outras duas entrevistas, realizadas fora do município de São Paulo, não foram gravadas por falha no equipamento. As anotações por nós realizadas ao longo das entrevistas permitiram a reconstrução do material discursivo, que foi submetido às entrevistadas para as correções.

As demais entrevistas realizadas junto às enfermeiras foram transcritas por profissional especializada. A análise do material foi operacionalizada através da técnica de análise de conteúdo.

Segundo BARDIN (1979: 42) a análise de conteúdo é:

"um conjunto de técnicas de análise das comunicações visando obter, por procedimentos, sistemáticos e objectivos de descrição do conteúdo das mensagens, indicadores (quantitativos ou nāo) que permitam a inferência de conhecimentos relativos às condições de produção/recepção (vanáveis inferidas) destas mensagens."

O tema foi a unidade de registro utilizada para essa análise, já que ..."O tema é geralmente utilizado como unidade de registro para estudar motivaçōes de opiniōes, de atitudes, de valores, de crenças, de tendências, etc. (Bardin, 1979)

Para BARDIN (1979; 105-6) 
"tema é a unidade de significação que se liberta naturalmente de um texto analisado segundo certos critérios relativos à teoria que serve de guia à leitura.."

Segundo MINAYO (1993:209),

"fazer uma análise temática, consiste em descobrir os "núcleos do sentido" que compōem a comunicação e cuja presença ou freqüência de apanç̧ão podem significar alguma coisa para o objetivo analítico visado.... a análise temática se encaminha para a contagem de freqüência das unidades de significação como definitónias do caráter do discurso. Ou ao contrário, qualitativamente a presença de determinados temas denota os valores de referência ou modelos de comportamentos presentes no discurso."

"O tema enquanto unidade de registro, corresponde a uma regra de recorte (do sentido e não da forma) ... visto que o recorte depende do nivel de análise e não de manifestações formais reguladas...." (Bardin, 1979).

Assim, através de sucessivas leituras, tendo como pano de fundo o referencial da teoria dos principios da Bioética, os temas foram aflorando e agrupados conforme as semelhanças e diferenças. Posteriormente os temas foram agrupados tendo-se como eixo central a questão do consentimento esclarecido, da seguinte forma:

1. Unidade Temática: Decisão sobre o cuidado

1.1. Sujeito da decisão: profissional/usuário

1.2. Instrumentos para a decisão competência técnica, conhecimento cientifico, experiência profissional informação sobre o cliente 
informação para o cliente

condiçōes materiais para a efetivação de decisão

2. Unidade temática: Prestação de assistência

2.1. Assistência ao indivíduo, familiares e coletividade

2.2. Conduta tomada pela enfermeira frente à decisão do usuário sobre o seu processo saúde-doença 
Resultados e Análise 


\section{RESULTADOS E ANÁLISE}

\subsection{CAMPO DE ESTUDO}

Apresentamos a seguir, os serviços que se constituíram em local deste estudo.

O CSE1, foi criado em 1925, como um "Centro Modelo, dependente" de um estabelecimento de ensino superior, "para aprendizagem de pessoal da Inspectoria e para coordenação com o serviço afeto" ao mesmo (SÃO PAULO, 1925). Tinha como um de seus principais objetivos a educação sanitária, "ministrar lições de higiene infantil, profilaxia da tuberculose e das moléstias venéreas junto às familias pobres ...."(Ribeiro, 1993: 258-9)

O CSE1 foi criado na fase higienista da saúde pública e atualmente está ligado administrativamente à uma unidade de ensino que tem por caracteristica principal a formação de recursos humanos em nivel de pós graduação senso lato e estrito.

Localizado em bairro de classe média, média alta, tem como população alvo aquela residente em sua área de atuação, que compreende dois bairros da cidade de São Paulo, além de alunos, docentes e funcionários da unidade de ensino. 


\section{Resultados e Análise}

Funciona das 7 h00 às $16 \mathrm{~h} 30$ para o desenvolvimento de suas atividades "normais" e das $16 \mathrm{~h} 30$ às $20 \mathrm{~h} 00$ horas para as chamadas atividades especiais, a saber, Acupuntura e Grupo de Lesões por Esforço Repetitivo (LER), alguns dias da semana. São desenvolvidas atividades nos programas de Saúde do Adulto, Saúde da Mulher, Saúde do Adolescente, Saúde da Criança, Vigilância Epidemiológica, Dermatologia Sanitária, Tisiologia, Oftalmologia, Fonoaudiologia, Nutrição, Saúde Mental, Homeopatia, Programa de Atendimento a Vitima de Abuso Sexual - PAVAS; além de ter atividades com grupos de: verminose, pré natal, planejamento familiar, triagem se saúde mental; imunização, curativos, medicação, exame de eletrocardiograma e pronto-atendimento.

A unidade conta com um laboratório onde os materiais para exame são coletados e analisados. Em alguns casos, o material é encaminhado para outros laboratórios da rede pública.

As atividades extra-muros são desenvolvidas apenas quando motivadas por necessidade gerada pela vigilância epidemiológica de doenças de notificação compulsória, restringindo-se à cobertura de foco e a supervisāo de postos de vacinação credenciados.

O CSE1 participa da formação de alunos de diversos niveis e áreas, servindo de campo de estágio para o nível médio, graduação, aprimoramento, especialização e residência médica.

Nesse serviço há predomínio do modelo clínico, médico-cêntrico, de atendimento à demanda, com desenvolvimento de ações 


\section{Resultados e Análise}

predominantemente intramuros (consulta médica, atendimento de enfermagem, grupos, etc) nos programas especificos, e em algumas especialidades. O trabalho da enfermeira está voltado principalmente para a organização da assistência individual (elaboração de escalas, provisão de material). As atividades assistenciais programadas são as de grupo e em um dos setores, devido à falta de pessoal, a pós consulta é realizada por enfermeira. A assistência é estendida à família nos casos de tuberculose e hanseniase. As atividades em grupo oferecem à clientela oportunidade de discussão sobre problema ou estado de saúde especifico, seu tratamento e prevenção.

Em caso de necessidade os pacientes são encaminhados aos serviços do Hospital das Clínicas da Faculdade de Medicina da USP ou à Santa Casa de Misericórdia de São Paulo, mas sem garantia de que o atendimento será realizado.

A unidade conta com quatro enfermeiras, duas em regime de 30 horas semanais, uma em 36 horas semanais e uma em 20 horas semanais

O CSE2, foi criado pelo Governo do Estado em julho de 1947. através do Decreto-Lei 17.357 de 2/07/47, subordinado à Diretoria Geral do Departamento de Saúde da Secretaria de Estado dos Negócios da Saúde com os objetivos de exercer, dentro dos limites do município de atuaçāo, as funções de unidade sanitária e de Centro de Aprendizado de uma unidade 
de ensino superior. Em 1958, foi transferido para a Universidade de São Paulo, como Instituto Complementar da mesma (SERVIÇO, sd).

Está administrativamente subordinado à uma unidade de ensino que tem por características a formação de recursos humanos em nivel de pós graduação senso lato e estrito. Ao longo de sua história, o CSE2 foi se responsabilizando técnica e administrativamente por outros serviços em bairros periféricos do município que, posteriormente, foram se desligando devido à emancipação politica de alguns distritos e a municipalização dos serviços de saúde.

Atualmente, além das atividades e ações voltadas para o atendimento da comunidade geral, por delegação do Municipio, é o órgão responsável pelo Programa de Vigilância Epidemiológica, é Centro de Imunizaçāo do Municipio e é referência técnica do Programa Nacional de Imunizaçāo. (Serviço, s/d).

Os seguintes Programas são desenvolvidos na unidade: Saúde do Adulto; Saúde da Criança; Saúde da Mulher; Dermatologia Sanitária (Hanseniase, Doenças Sexualmente Transmissiveis e AIDS); Tisiologia; e Saúde Mental. Em termos de Vigilância epidemiológica: controle de cobertura vacinal do município, visita a serviços de saúde para notificação e acompanhamento de casos de doenças de notificação compulsória e outras de interesse do serviço, controle de tratamento e faltosos em programas especificos. Além disso faz busca ativa de casos de dengue, cobertura de focos de doenças de notificação compulsória. O serviço desenvolve ainda atividades de visita domiciliária, visita hospitalar, vacinação, aplicação de 
tratamentos (medicações e curativos), atendimento de enfermagem, pós consulta, atividades educativas em empresas da região, divulgação de informaçōes sobre saúde em programa radiofônico local e pronto atendimento.

Conta com um laboratório a exemplo do CSE1 e participa regularmente na formação de alunos dos cursos de Graduação em Enfermagem e de Auxiliar de Enfermagem de outras instituiçōes de ensino que aquela à qual está subordinado. Além disso recebe alunos de pós graduação e alguns profissionais de outros paises para estágio acadêmico.

A unidade conta com quatro enfermeiras, contratadas pela instituição de ensino, que trabalham 40 horas semanais, incluindo plantōes de fim de semana e feriados.

As enfermeiras são responsáveis administrativamente por programas especificos, cabendo a elas a sua coordenação e organização. Fazem supervisão do pessoal de enfermagem nesses programas e em relação à vigilância epidemiológica, realizam avaliação dos dados que alimentam o sistema de informações do serviço: vacinação, notificação de doenças, o seguimento de casos de doenças de notificação específicas. É interessante dizer que são responsáveis pela monitorização do programa de vacinação no municipio.

A prática assistencial das enfermeiras está voltada tanto para o atendimento individual, como o coletivo, com grande ènfase na vigilância 
epidemiológica, dirigida não só às doenças de notificação compulsória mas tambèm à saúde materno-infantil e ao aumento da cobertura vacinal.

Este serviço tem programas de informática especificos para o controle da vacinação no municipio, inclusive das crianças vacinadas em postos credenciados pelo CSE e para o controle dos casos de doenças de notificação compuisória. Estes programas possibilitam a convocação de faltosos à vacinação (ou sua vacinação no domicílio, nos casos de crianças que moram em zona rural), aumentando assim, a cobertura vacinal no município

O CSE3. é uma unidade docente-assistencial, gerenciada pelo Departamento de Medicina Preventiva de uma Faculdade de Medicina, que conta com apoio e supervisão técnica do Departamento de Pediatria e de um curso de Fonoaudiologia e para efeito de execução de açōes de saúde, está subordinado às instâncias centrais, regionais e municipais do Sistema Único de Saúde. Desde 1977, trabalha na construção de modelos assistenciais em atenção primária à saúde em conjunto com o Departamento de Medicina Preventiva

Seu horário de funcionamento é das 7 às 18 horas de segunda à sexta feira. Os Programas desenvolvidos são os seguintes:

Saúde do Adulto: saúde e envelhecimento, controle de doenças crônicas; saúde da mulher; assistência pré natal; e saúde do adolescente. Saúde da criança: terapia de reidratação oral; atendimento em programas: crescimento 
e desenvolvimento, vigilância alimentar e nutricional, controle das doenças respiratórias na infância, e controle de saúde em creches. Saúde Mental: grupo diagnóstico; assistência a psicóticos; psicoterapias a não psicóticos e terapia ocupacional. Saúde Bucal: vigilância e assistência da gestante e vigilância e assistência da criança na primeira infância. Fonoaudiologia em Atenção Primária: diagnóstico e segmento terapêutico de distúrbios primários da linguagem; vigilância à saúde do trabalhador. Epidemiologia e Vigilância Epidemiológica em Saúde: unidade de vigilância epidemiológica, vigilância em saúde; estatísticas médico-sanitárias e avaliação do serviço; e vacinação. As atividades desenvolvidas nos programas são: consultas médicas, consultas de enfermagem, visitas domiciliárias, trabalhos em grupo, coleta de material para exames, aplicação de tratamentos, atendimento de enfermagem (individual e em grupo), atividades educativas (na unidade), realização de ECG e colaboração com o jornal do bairro. O pronto atendimento é realizado nos 4 primeiros programas citados.

O CSE3 participa da formação de alunos dos cursos de: Graduação em Medicina, junto a alunos do $3^{\circ}$ ao $6^{\circ}$ ano; Enfermagem, nas disciplinas de Administração, Saúde Coletiva, Saúde da Criança; Fonoaudiologia; Psicologia e Terapia Ocupacional. Recebe também alunos de Aprimoramento em Saúde Coletiva para profissionais de nivel superior; não médicos e residentes dos Cursos de Medicina Preventiva, Clínica Médica e Pediatria e alunos do Curso de Auxiliar de Enfermagem do Hospital Universitário (HU) da Universidade de São Paulo. 
A unidade conta com três enfermeiras, sendo que uma delas é enfermeira do Ministério da Saúde (MS), comissionada no serviço há um ano. As enfermeiras da Universidade trabalham 32 horas semanais e a do MS, 30 horas semanais.

Nesta unidade, a chefia de enfermagem tem papel coordenador, acumulando ainda a chefia do setor de estatística e epidemiologia. $\dot{E}$ responsável pela coordenação dos estágios de alunos da área de enfermagem.

As enfermeiras realizam algumas atividades de ensino de forma mais sistemática junto a alunos de graduação em Medicina, no treinamento de funcionários, na realização de seminários com residentes de clínica médica e aulas sobre vigilância epidemiológica a aprimorandos. Esporadicamente, desenvolvem atividades didáticas em outras instituições assistenciais e de ensino.

Em termos de pesquisa, uma das enfermeiras,participa de vários estudos, na qualidade de coordenadora de campo e também na sua elaboração. Outra enfermeira participa nas atividades de campo dos estudos, na captação de usuários, seu esclarecimento, obtenção de consentimento para participação em pesquisa, seu atendimento e acompanhamento.

Neste serviço, as enfermeiras são instadas a participar de atividades e reuniões científicas do Departamento de Medicina Preventiva. 
O CSE4, foi criado através de convênio entre uma fundação privada filantrópica e a Secretaria de Estado da Saúde de São Paulo em 1967 e iniciou suas atividades em 1968, com o cadastramento das familias residentes em dois bairros da cidade, que compreendem a área de atuação do serviço. O atendimento médico foi iniciado em 1969. O serviço está ligado aos departamentos de Medicina Social e de Pediatria de uma Faculdade de Medicina.

Em estudo realizado por SILVEIRA (1999), verificamos que este centro de saúde escola e um outro criado na mesma época, foram os primeiros a ter como atribuição a responsabilidade pela saúde pública de uma determinada área da cidade. Localizada de inicio "praticamente dentro da favela", em área com forte presença de indústrias pequenas, médias e grandes, hoje se localiza entre duas grandes avenidas, atendendo à população moradora de sua área de atuação, bem como os trabalhadores das indústrias e empresas da região, além de moradores "de rua". A população residente na localidade caracteriza-se pela presença de imigrantes recentes e antigos e migrantes, principalmente da Região Nordeste do pais.

A unidade funciona de segunda à sexta-feira, das 7 às 17 horas. Os programas e atividades desenvolvidos intramuros são os seguintes: assistência em pronto atendimento e atividades programáticas em: Saúde da 
Criança, Saúde da Mulher, Saúde do Adulto, Saúde do Trabalhador, Saúde Mental, Odontologia, Tuberculose, Hanseníase, Vigilância Epidemiológica de doenças de notificação compulsória e de eventos de interesse para o serviço como o câncer de colo uterino, as doenças da infância, a vigilância de gestantes. Medicação, curativos, inalação, imunização, eletrocardiograma (ECG) e grupos: de hipertensão, diabetes, gestante, papanicolau, resultado de papanicolau, triagem da saúde mental e planejamento familiar.

Tem por atividades extra muros: visita domiciliária (em caso de matriculas novas para confirmação de endereço, levaritamento das condições de vida; de doenças de notificação compulsória; papanicolau ou; exames de sangue muito alterados (por exemplo, glicemia $350 \mathrm{mg}$ para pessoa com retorno agendado para uma data muito distante); assistência domiciliária, geralmente a idosos; trabalho com moradores de rua; grupo de hipertensão em instituições (empresas); e grupo de planejamento familiar (empresas e instituição de assistência a mulheres marginalizadas "profissionais do sexo" e de moradoras de rua).

O CSE4 participa mais intensamente da formação de alunos do curso de graduaçāo em Medicina, da unidade de ensino a que está vinculada, através da orientação para atividades de estágio e aulas regulares, praticamente durante todo o ano; e de residentes da mesma Faculdade nas áreas de Medicina Social, Pediatria e Psiquiatria.

Conforme podemos verificar, a programaçāo tem uma conotaçāo mais comunitária, o serviço tem uma relação histórica com a população de 
seu território de atuação desde sua criação, inclusive com a incorporação de segmentos sociais que normalmente não sāo assistidos em serviços de saúde como moradores de rua e "profissionais do sexo".

O CSE4 conta com três enfermeiras, duas com jornada de trabalho de 40 horas e uma de 30 horas que desenvolvem atividades de organização e coordenação dos programas pelos quais cada uma é responsável (Assistência domiciliar, Vigilância Epidemiológica), supervisão do pessoal auxiliar nos diversos setores, pedido de vacina, controle de estoque, reuniões com a equipe de enfermagem, treinamentos, contatos com outras instituições, elaboração de normas e rotinas de enfermagem $€$ participam de reuniōes com a equipe de saúdé. As atividaudes ássistêtriciáis programadas são a assistência domiciliar, o atendimento de enfermagem e grupos no pré natal e no planejamento familiar. consulta de enfermagem para a tomada de medida de diafragma e orientação de uso e supervisão na colocação do mesmo, coleta de material para papanicolau incluindo a colheita de material a fresco e teste de amina.

Eventualmente realizam consulta de enfermagem a hipertensos, gestantes, mulheres em situação de violência, e fazem orientação para o paciente de planejamento familiar. Além de desenvolverem atividades educativas junto a escolares.

Em termos de ensino, ministram regularmente aulas sobre temas relacionados à sua prática (Vigilância Epidemiológica, Assistência domiciliar a alunos de graduação de Medicina da Faculdade a que estão vinculadas e 
supervisionam atividades de estágio relacionados a vigilância epidemiológica. Coordenam atividade de pesquisa sobre mortalidade materna realizada pelos alunos da faculdade de medicina à qual o serviço está vinculado.

Através de informaçōes obtidas junto às enfermeiras e alguns diretores de serviço, verificamos que todos os serviços estão ligados administrativa e tecnicamente a unidades de ensino superior, sendo uma à uma fundação e à uma Faculdade de Medicina, outra à uma Faculdade de Medicina e duas à Faculdade que forma recursos humanos em nivel pós graduação lato e senso estrito na área de saúde coletiva.

Sua criação se deu em diferentes épocas, seguindo modelos técnicos assistenciais diferentes: higienista, programação, saúde comunitária. Atuaimente todos afirmam seguir o modelo Programático.

Desenvolvem suas atividades através de diversos programas em comum, atendendo a populaçāo de suas áreas de atuação nas áreas de saúde do adulto, saúde da mulher e da criança e Vigilância Epidemiológica.

A tisiologia e a dermatologia sanitária sāo especialidades que foram incluidas nos programas básicos de saúde do adulto, da mulher e da criança em algumas unidades e são setores específicos em outras.

Uma das unidades, além dos programas básicos, desenvolvem especialidades de homeopatia e acupuntura, além de programa especial de Lesōes por Esforços Repetitivos junto a bancários. 
A prática assistencial nesses serviços varia de acordo com a unidade, mas a prática clinica é a que prevalece.

Duas das unidades desenvolvem atividades extra-muros com mais intensidade; uma principalmente para a vigilância epidemiológica, e outra para assistência domiciliar e atividades na comunidade. A primeira inclusive, desenvolve açōes de vigilància epidemiológica, a vacinação de recémnascidos e orientação a puérperas em hospitais do municipio.

O CSE2 é a única unidade que funciona nos finais de semana e feriados, desenvolvendo atividades de pronto atendimento, controle de raiva, vacinação, visita domiciliária e vigilância epidemiológica.

Alguns funcionários das unidades ligadas a Faculdades de Medicina participam de reuniōes regularmente nos Departamentos de Medicina Preventiva ou Social e desenvolvem atividades junto a acadêmicos dessas faculdades.

\subsection{OS SUJEITOS DA PESQUISA}

Foram entrevistadas 13 enfermeiras lotadas nos 4 CSEs selecionados. Segundo informaçōes por elas fornecidas, podemos dizer que a grande maioria é formada há mais de 13 anos, em escolas públicas (oito) e trabalha no serviço há mais de 5 anos (sete), sendo que destas, cinco o fazem, há mais de 10 anos. Em termos de experiência profissional prévia, onze delas desenvolveram suas atividades profissionais em outros serviços de saúde, como hospitais públicos e privados e principalmente unidades de 
saúde da rede pública, inclusive unidades de referência e de nível municipal e regional.

Todas, sem exceçāo, fizeram algum curso após o término da graduação: 9 cursaram Habilitaçōes em Enfermagem (sendo 5 em Saúde Pública); 4 especializaram-se em Enfermagem Obstétrica, 7 em cursos de especialização ou aprimoramento em Saúde Pública ou Coletiva e duas em Administração Hospitalar. Apenas uma delas fez mestrado em Enfermagem, desenvolvendo estudo sobre o Programa Nacional de Imunização.

Em relação ao regime de trabalho, verificamos que variou conforme as unidades e dentro das próprias unidades. Do total, seis trabalham em regime de 40 horas semanais, três 30 horas, duas 32 horas, uma 36 horas e uma 20 horas semanais, serido que as enfermeiras que trabalham 40 horas semanais são aquelas lotadas no CSE2 e CSE3, as unidades em que as atividades extra-muros são desenvolvidas mais intensamente que nas outras.

Em termos funcionais, dez são contratadas pela instituição de ensino a que o CSE está ligado, duas sāo enfermeiras do Ministério da Saúde, prestando serviços nos CSEs, e uma foi contratada como prestadora de serviço após sua aposentadoria no pelo próprio CSE em que trabalhava anteriormente.

Todas desenvolvem alguma atividade administrativa: coordenação de programa; organização do serviço para a assistência; supervisão de 
pessoal de enfermagem. Participam no desenvolvimento de programas, principalmente no tocante às atividades da enfermagem.

As enfermeiras lotadas em unidades ligadas a faculdades de medicina desenvolvem atividades de ensino regularmente junto a acadêmicos desse curso. Todas desenvolvem atividade de apoio a estágios de outros cursos de graduação e de auxiliar de enfermagem, sendo geralmente a chefe do setor de enfermagem quem coordena os diversos estágios realizados na unidade, inclusive de profissionais de outra área, que não a médica.

As atividades assistenciais identificadas por elas sāo as de prestação de assistēncia direta ao usuário através de pré e pós consulta, vacinaçāo, consulta de enfermagem, atendimento de enfermagem, visita domiciliária e atividade educativa junto à comunidade (escolares, indústrias). Algumas incluem nessa atividade assistencial aquelas da vigilância epidemiológica (controle individual, notificação e vigilância), a divulgação de conhecimentos através de programas radiofônicos ou em jornais.

Essas atividades assistenciais, segundo as enfermeiras, sāo as agendadas ou planejadas: consulta de enfermagem, grupos, assistência domiciliar, visita domiciliária, pós consulta; e as chamadas eventuais, entre as quais incluem o "encaixe" de solicitações de consulta médica fora do agendamento do dia (através da verificação de queixa e de sinais vitais, para posteriormente verificar a possibilidade de atendimento) e as atividades que normalmente são desenvolvidas por pessoal auxiliar de enfermagem e que 
as enfermeiras desenvolvem na falta desse profissional: pré e pós consulta e atendimento de enfermagem.

Apesar de termos observado que em algumas unidades a atividade de "encaixe" de consulta ser rotineira, as enfermeiras a consideram uma atividade eventual, não programada, que dentro de seu cotidiano toma tempo e interrompe suas atividades administrativas. As enfermeiras não classificam esta atividade como sendo de triagem, que seria uma atribuição do profissional médico e não da enfermeira.

É interessante dizer, que tanto a atividade de pós consulta como a de atendimento de enfermagem e a de vacinação são vistas pelas enfermeiras de formas diferentes no que diz respeito ser atribuição ou compartilhada com o pessoal auxiliar de enfermagem ou de substituição a esse profissional.

Estas atividades são vistas pelas enfermeiras de alguns dos CSEs como atividade compartilhada nos diversos setores, pois consideram-nas como uma forma de manter contato direto com a clientela que comparece ao serviço em busca de assistência, fazer o acompanhamento e o controle dos casos (principalmente de vigilância epidemiológica) e fazer a supervisão do pessoal auxiliar.

Em outras unidades, são feitas apenas na falta eventual do pessoal auxiliar, para garantir que a atividade seja realizada. Nestes casos, percebemos a frustração das profissionais que dizem 


\section{3. ANÁLISE DOS TEMAS}

Os dados obtidos através das entrevistas e da observação participante evidenciam que as enfermeiras dos centros de saúde escola desenvolvem atividades assistenciais junto ao usuário individual e/ou coletivo de forma sistemática, planejada ou não e que essas ações são basicamente voltadas para o controle e prevenção de doenças, a promoção da saúde ${ }^{8}$, para o desenvolvimento do auto-cuidado ${ }^{9}$ e a organização do serviço para a assistência.

As enfermeiras, elencaram como atividade assistencial aquelas identificadas como as de cuidado direto: consulta de enfermagem, vacinação, atendimento de enfermagem (quando dizem substituir pessoal de nível médio nesse atendimento), orientações de pós consulta médica, assistência domiciliar, visitas domiciliárias (ou a instituições tipo escolas,

\footnotetext{
${ }^{8}$ Promoçāo da Saúde, segundo a Carta de Ottawa, de 1986 envolve cinco pontos: (a)o reforço da ação comunitária favorecendo a participação efetiva da comunidade à todas as etapas de elaboração, e de planejamento dos programas de promoçăo de saúde. Esta participação contorna o desenvolvimento individual e social e requer um total e constante acesso à informação e à educação sanitária, assim como à ajuda financeira; (b) a aquisição e 0 aperfeiçoamento pelas populações de atitudes individuais, de forma a exercer um maior controle sobre sua própria saúde e meio ambiente; (c) a elaboração de uma política pública sã.; (d) a criação de meios favoráveis para mudança nas formas de vida, trabalho e lazer que afetam de forma significativa a saúde; e (e) a reorientação dos serviços de saúde para as atividades de promoção de saúde, de forma a deixar de ser meramente responsável por proporcionar serviços clínicos e médicos.

${ }^{9}$ Auto-cuidado, segundo Orem (1991:117- 119) è a prática de atividades iniciadas e executadas pelos indivíduos, em seu próprio benefício, para a manutenção da vida, da saúde e do bem estar. Parte do pressuposto que é uma conduta que é aprendida e que pessoas adultas tèm o direito e a responsabilidade de cuidarem de si mesmas para manter a vida e a saúde de forma racional e que podem ter essa responsabilidade por outras pessoas (prestar cuidado a crianças, idosos, ou mesmo supervisionar o seu auto-cuidado). Foi Dorothea Orem que desenvolveu a Teoria do Auto Cuidado em enfermagem. Ver George JB. e Col. Teorias de enfermagem: os fundamentos para a prática profissional. Porto Alegre, Artes Médicas, 1993 C.7, Orem DE. Nursing: concepts of practice. St. Louis, Mosby Year Book, 1991 e Pearson A., Vaughan B. O modelo de enfermagem de Auto cuidado In: Modelos para o exercicio de enfermagem. Londres, Heinemann Medical Books, 1986. - tradução de M.J. Simeão.
} 
fábricas, hospitais) e atividades em grupos operativos. Além disso, a maioria delas afirma desenvolver ações de Vigilância Epidemiológica, ou seja, notificação, atendimento, controle, busca ativa de casos, visitas, etc. Conforme verificamos na observação participante, essas atividades assistenciais são realizadas com maior ou menor freqüência, de acordo com a unidade. Aparentemente, os fatores determinantes dessas diferenças são o número de profissionais disponíveis nos períodos de trabalho e o modelo tecno-assistencial adotado.

É interessante ressaltar que ao indagarmos qual o modelo assistencial desenvolvido nas unidades, verificamos que a resposta, invariavelmente foi: "programático" ${ }^{10}$. No entanto, durante as entrevistas e as observações, verificamos que a operacionalização desse modelo tecnoassistencial se diferenciava: ênfase à vigilância epidemiológica, à assistência à comunidade e à programação.

Como já foi relatado no item "procedimentos metodológicos", partimos de três perguntas básicas:

"Tente se lembrar das atividades desenvolvidas no dia de ontem:

- Em quais tomou decisões que diziam respeito ao cuidado ao cliente?

\footnotetext{
${ }^{10}$ A Reforma Administrativa de 1969 na Secretaria de Estado da Saúde de São Paulo possibilitou o desenvolvimento de um modelo tecnológico da Saúde Pública Paulista caracterizado pela ampliação e diversificação da assistência médica individual denominado "Programação em Saúde" e os programas de saúde foram operacionalizados na rede de Centros de Saúde até 1983. Villa TCS, Mishima SM, Rocha SMM. (1997). Segundo Schaiber (1990) Programação em saúde enquanto "modelo assistencial", está baseado no planejamento ascendente, de base local, tendo como principio a integração sanitária, a hirarquização do cuidado, a centralização normativa e a avaliação.
} 
- De que forma essas decisōes foram tomadas? O que você levou em consideração?

- A quem cabe a decisão sobre o cuidado?

que levaram as enfermeiras a relatar casos e informar sobre sua prática.

As falas significativas que têm relação com os objetivos do trabalho foram selecionadas e categorizadas de forma a sistematizar as informaçōes obtidas.

$\mathrm{Na}$ Unidade Temática DECISÃO SOBRE O CUIDADO, encontramos o núcleo de pensamento QUEM DECIDE. Através das falas, podemos interpretar que a decisão cabe ao PROFISSIONAL, ao USUÁRIO ou é COMPARTILHADA.

No primeiro grupo, estão incluidas as profissionais de enfermagem e outros elementos da equipe de saúde. A decisão sobre o cuidado a ser prestado, se dá através de protocolos definidos pelo conjunto de profissionais da equipe de saúde e, no caso de prescrição de medicamentos, pela equipe médica"1.

No discurso verificamos que as enfermeiras afirmam que as decisōes cabem ao profissional quando envolvem a prescrição de medicamentos previamente estabelecidos em rotina pela equipe médica para alguns sinais, sintomas e afecções dos usuários. Devemos ressaltar que

\footnotetext{
11 A prescrição de medicamentos pela enfermeira é prevista na Lei do Exercicio Profissional (Lei 7498/86 Art. 11, II, c).
} 
apesar da rotina prever a prescrição, ela cabe à enfermeira a interpretação dos sinais e sintomas, dos resultados de exames e testes para a tomada de decisão seguindo aquele padrão.

(No Programa da) "Saúde da mulher tem ... rotinas .... tudo colocado (previamente pela equipe médica). Nem só porque é mais antigo, mas porque a gente faz abordagem sindrômica ${ }^{12}$. A gente faz a coleta do Papanicolau, o exame à fresco, teste de amina e a gente prescreve. Então, como .... a gente não pode estar prescrevendo, a instituição fez um papel com tudo padronizado e autoriza a gente a estar prescrevendo aquelas medicações .... então, por exemplo, se chega alguém com temperatura alta a gente também prescreve, então tem algumas medicações que já está definido que a gente pode estar ... (prescrevendo)

“... para esses casos (corrimento vaginal) existe padronização ${ }^{13}$. Por isso que eu espero (o resultado do exame) para dai tratar .... Podena ter entrado com paliativos, banho de bicarbonato, vinagre ... mas eu preferi esperar para não mascarar ... antes de colher o exame .... e como ela usa diafragma, dependendo do que for pode impregnar o diafragma e aí ela não vai curar nunca, então prefen que ela fosse colher o exame e com o resultado ela trataria ou não".

Por outro lado, conforme podemos verificar no discurso abaixo, uma das entrevistas afirma que sendo necessário um tratamento, a decisão

\footnotetext{
${ }^{12}$ A definição de Abordagem Sindrômica utilizada nesse CSE é a preconizada pelo Ministério da Saúde no Programa Nacional de Controle de DSTIAIDS: "Em uma única consulta, prover o paciente: avaliação, terapêutica e aconselhamento adequado" visando a quebra da cadeia epidemiológica.
} 


\section{Resultadas e Análise}

cabe ao profissional, que sabe qual seria o adequado para ele, numa clara atitude paternalista, como definida por Culver e Gert (1982). Ainda neste discurso, a enfermeira afirma que não há garantia de que o tratamento será realizado, isto é, a decisão sobre o uso ou não da medicação prescrita é de responsabilidade do usuário. Assim, não sendo apresentadas opções de tratamento, resta ao usuário apenas decidir se irá se tratar ou não.

“... daí eu vou dar um tratamento. E eu explico que tem que fazer, porque senão vai ficar sempre com esse corrimento, né, o que vai acarretar no futuro, para ela e para o marido. Se ela não usar, volta comigo - não tratei -, aí você vai tentar de novo. isso não dá para ela decidir por ela, isso é um tratamento, quando é para escolher usar ou não o método (contraceptivo), tudo bem, mas um tratamento não dá para escolher, terá que fazer, entāo a gente tenta mostrar. Agora, garantia, nunca terei essa garantia.

Foram incluídos, também neste grupo, os cuidados prestados em casos de urgência (crise hipertensiva, crise convulsiva e pré-eclâmpsia), nem sempre de "iminente risco de vida", como incluido no Código de Ética dos Profissionais de Enfermagem, mas que no julgarnento dessas enfermeiras não se tem condições para informar ao usuário sobre o que será feito, deliberar sobre as melhores opções de tratamento ou cuidado e pedir sua participação na tomada de decisão.

\footnotetext{
${ }^{13}$ Padronização: o tratamento de determinadas afeç̧ōes e sintomas segue um modelo estabelecido pela equipe técnica do serviço.
} 
“... E tem coisas que são emergenciais mesmo. O paciente é hipertenso e ele está em crise hipertensiva agora, .... quem tem que decidir somos nós .... porque se a gente não decide agora ele morre .... Ai depois que você tira da crise hipertensiva, ai tudo bem, aí você vai trabalhar ..."

"se ele estiver passando mal, e se recusa a receber medicação para parar de convulsionar, não dá para esperar, a gente aplica."

"Acho que existem momentos que você precisa ... decidir, entre aspas, por ele. Por exemplo, uma paciente que era hipertensa no último mês da gestação. Ela não queria ir para a Santa Casa .... , porque ela não gostava, e queria só ficar vindo aqui .... gente falou - você vai, porque se você nāo for não te atendemos mais aqui .... você tem que ir, a gente não vai dar conta das coisas aqui ... ou então você morre e morre o nené .... E ela aceitou. Mas isso eu acho que tem que ter muito cuidado. Até antes de você decidir pelo paciente você tem que criar um vínculo de confiança, porque senão ele não aceita a sua decisão.

Esse último discurso é interessante pois apesar de dizer que "existem momentos que vocè precisa ... decidir, entre aspas, por ele" (usuário), a entrevistada cita como exemplo um caso em que os profissionais de saúde explicaram à gestante hipertensa, que se recusava a ir ao hospital, sobre a necessidade de ser atendida naquela unidade, sobre a limitação do serviço para atendê-la diante do seu quadro clínico, e os riscos a que estaria expondo a si mesma e ao concepto. Assim, o "decidir entre aspas, por ele", representou na realidade, uma maior dedicação por parte da profissional na exposição dos argumentos que fundamentavam tal conduta e não tomar a 
decisão por ela. Além disso, sendo o pré-natal desenvolvido em um período de tempo considerável, foi possivel estabelecer vínculo de confiança tanto técnica como afetiva, o que na visão da enfermeira, com a qual concordamos plenamente, levou a usuária acatar a orientação da equipe.

As enfermeiras informam, também, que nos casos de limitação intelectual, deficiència mental e física o usuánio não pode participar da decisão sobre o seu cuidado, cabendo ao profissional fazè-lo.

“... um paciente com rebaixamento, .... a gente tem vánios pacientes assim ... existe um limiar de entendimento, em que a gente, claro, não ignora, mas que a gente solicita a presença de um familiar para nos ajudar nessa tarefa.

"se ele estiver impedido do entendimento sobre o cuidado. Ai é um problema mesmo limitante dele. Do contránio eu acho que ele pode todas as vezes.

....uma limitação intelectual, mental, eu acho que essa pode ser. Ele pode ter uma incapacidade fisica ...."

Como referido anteriormente no referencial teórico, para que uma pessoa desenvolva sua autonomia são necessános alguns requisitos biológicos, psíquicos e sócio culturais que determinam a competência para decidir. A literatura mostra, que pessoas que apresentem essas condiçōes, principalmente as duas primeiras não devem ser consideradas totalmente incompetentes para tomar toda e qualquer decisão (Muñoz \& Fortes, 1998). 
"A loucura não priva o ser humano de sua capacidade de julgamento, de tomar decisōes, portanto de sua condição de sujeito" (Naffah Neto, A. 1998). Por exemplo, uma pessoa com alguma limitação intelectual pode ser considerada incompetente para se auto medicar, mas competente para tomar decisões autônomas quanto à sua alimentação.

Quanto à limitaçāo física, pode haver autonomia de vontade e não de ação. Assim, é possivel que, em sendo esclarecido qual o cuidado a ser prestado, o usuário participe na tomada de decisão, desde que ele tenha elementos que possibilitem a execução desse cuidado.

Ainda em relação a condições que dificultam a participação do usuário nas decisōes, uma das enfermeiras afirma que o serviço tem limitado o atendimento ao usuário no caso de comparecimento ao serviço em estado alterado pelo consumo de drogas, orientando-os a comparecer ao serviço quando estiverem melhor. Conforme citado anteriormente por Muñoz e Fortes (1998: 59), desordens emocionais, além de outras, podem reduzir a autonomia do individuo, fazendo com que as decisōes sejam tomadas por terceiros, familiares ou mesmo pelo profissional de saúde. Os usuánios que comparecem drogados ao serviço têm sua competência alterada naquele momento, assim, o serviço estaria agindo em benefício do usuário, não o atendendo nessas condiçōes e promovendo, ou melhor, possibilitando a sua participação nas decisões sobre seu cuidado quando não estiver sob os efeitos das drogas. Entretanto, como podemos verificar através do discurso, o adiamento do atendimento se dá para, aparentemente, disciplinar o usuário 
que tumultua o andamento do serviço e possibilitar um melhor atendimento a outros usuários.

... O usuário de droga, ele tem por característica, .... ele não tem limite das coisas. Ele vem, invade o seu espaço, invade a privacidade daquele paciente que você está atendendo, isso acontece muito. Ele é impaciente porque ele quer ser atendido naquele momento, da necessidade dele, tá, então ele te agride muito. $E$ eu tenho, aqui no serviço, por exemplo, usuánio de droga, que ele vem "loucão"... ele nāo é atendido pelo médico. Ele não é atendido, entāo esse é um limite que acho que pela própria experiência deles, que eu não vivi, chegou-se a esse consenso. Então, ninguém vai ser atendido, o médico não vai marcar consulta, não vai atender em consulta naquele momento se ele estiver "dopadão", "loucão". Entāo, e é interessante, porque o paciente nāo vem mais daquele jeito.

... O usuário de drogas menor de idade vem acompanhado. A gente atende ...

No caso de menores nessas condições, o atendimento é realizado se ele estiver acompanhado pelo responsável, o que nos levou a concluir que a enfermeira considera o responsável como aquele que toma as decisões por ele, sem a sua participação consciente.

As enfermeiras afirmam que o profissional de saúde tem uma certa "autoridade" sobre o usuário, faz com que ele concorde com a conduta indicada pelo profissional. Ora, o profissional realmente tem um poder advindo de um maior saber, da possibilidade de selecionar a informação a ser dada ou omitida e inclusive a forma como será oferecida. A utilização de 
linguajar científico também é uma forma de demonstração de poder ${ }^{14}$. Paralelamente, o locus em que se dá a atividade assistencial geralmente é o do profissional.

\begin{abstract}
“ O paciente precisa saber o que está acontecendo com ele, o que está sendo investigado .... O que acaba acontecendo é que ele concorda. É que ele tem uma autoridade, entre aspas, na frente dele, ele acaba aceitando..
\end{abstract}

Uma das enfermeiras diz que o profissional é o dono do saber e das condições e que às vezes, (grifo nosso) o "paciente (deve) ... ser dono também”, já que o profissional não sabe o que ele quer

\begin{abstract}
“...porque o profissional, ele fica atrás da mesa, é o dono do saber... é dono das condiçōes. E o paciente está ali, sentindo tudo na came. A gente tem também às vezes, que inverter as coisas... 0 paciente ser dono também. Você tem que dar o direito para ele ...não somos nós que sabemos o que ele quer..."
\end{abstract}

A enfermeira afirma que cabe ao profissional fazer essa inversão aparentemente, como uma concessão.

As enfermeiras também afirmam que a decisão sobre o cuidado cabe a elas ou a elementos da equipe de enfermagem, como vemos nas falas abaixo:

\footnotetext{
${ }^{14}$ Boltansky L. As classes sociais e o corpo. Rio de Janeiro: Graal: 1979, discute a relação doente-médico no que diz respeito à distância social, as formas de comunicaçāo, as categorias da percepção do profissional em relação ao doente e as estratégias utilizadas pelo médico nessa relação.
} 
A decisão sobre o cuidado cabe a "uma enfermeira ou a uma auxiliar..."

“Eu acredito que é a equipe de enfermagem. A enfermeira estando presente ela pode estar coordenando, planejando junto. E na ausência dela, tem que dispor de um auxiliar devidamente treinado na funçāo que ele estiver executando, né."

Entretanto, as mesmas enfermeiras, ao serem indagadas sobre a participação do usuário, afirmam que ela é fundamental, já que, a principal ação por elas desenvolvidas é a orientação ou o ensino para o auto-cuidado,

Segundo os sujeitos da pesquisa, a decisão do cuidado cabe principalmente ao USUÁRIO, pois na maior parte das vezes esse cuidado será executado no seu domicilio. Não havendo aderência à orientação dada, o cuidado não é realizado. A enfermeira dá informações; o serviço, por vezes oferece medicamento ou material, mas o sujeito executor da ação é o usuário.

A decisão cabe "a ele, né .... A gente tenta orientar, deixar ele consciente do que ele tem .... o que ele pode fazer para melhorar, para não pegar de novo. Mas a opção se ele vai tomar o remédio ou não .... é dele .... A gente dá, ele leva para casa ...

“... Mas eu acredito nisso, acredito que a decisāo tem que ser do paciente, porque quando ele decide, quando a opção é dele, a adesão ao tratamento e ... cuidados, è muito melhor. Ele cria vínculo com você, ... tem mais eficácia o tratamento.

Em contraste à figura de autoridade do profissional, relatada em caso anterior, vêem a participação do usuário como uma questão de 
cidadania, ou melhor, de promover o exercicio da cidadania, uma preocupação demonstrada pelas enfermeiras em sua atividade profissional.

“ A decisão final cabe à paciente, ao paciente. Nāo tem como não ser. Porque a gente trabalha tanto, até dentro do grupo a questão da cidadania ... então cabe ao paciente mesmo."

Deixam claro também, que a orientação ao usuário é fundamental. Falam sobre a importância de esclarecer o diagnóstico, a evolução da doença, a importância do tratamento e do seu controle. No caso de grupos operativos (de planejamento familiar e aleitamento materno), as enfermeiras apresentam as opções existentes, seus benefícios e riscos, o que, além dos discursos, verificamos ser realidade na observação das atividades das enfermeira. Ora, o oferecimento de informações e de opções são dois dos requisitos básicos para o exercício do consentimento esclarecido.

"... No final do grupo eu falo ... - estou passando conhecimento para vocès ... e a partir desse conhecimento vocês têm livre arbitrio ... ou vocês amamentam ou não. - ..., acho que ela tem direitos sobre o corpo dela. Desde que você coloque os riscos e beneficios, ela faz a opçāo dela.

No tratamento medicamentoso, opções são apresentadas quando cabe à enfermeira prescrever medicações delegadas pela equipe médica e previstas em protocolos ou padronizações:

"primeiro a gente pergunta se a pessoa tem úlcera, se ela tem algum problema gástrico. Porque ai nem adianta dar que ela não vai conseguir 
tratar. Se não tiver nada, a gente fala - olha, estou te dando um remédio que a gente tem aqui,.... não vai gastar nada. Mas se não conseguir tomar esse remédio, você volta, procura a gente ... que tem outros remédios, mas que custam um pouquinho caros ... - , ou se a pessoa falar na hora - nāo, eu posso comprar o outro, prefiro o outro -, ai a gente nāo dá Metronidazol ... ai você dá uma outra medicação que vai ser mais cômodo para ela, ela pode optar.

Quando a prescrição é médica, a enfermeiras cumprem o Art. 30 do Código de Ética dos Profissionais de Enfermagem aprovado em 1993 (Brasil,1996): "Colaborar com a Equipe de Saúde no esclarecimento do cliente e familia sobre seu estado de saúde e tratamento, possiveis beneficios, riscos e conseqüências que possam ocorrer."

Apesar de dizerem que a decisão sobre o cuidado cabe ao usuário, afirmam que essa decisão se dá na ação de utilizar medicamento ou não. Foram poucos os casos em que foram apresentadas opções que permitissem a deliberação e a decisão por parte do usuário.

A decisão sobre que cuidado ou tratamento a seguir também pode ser COMPARTILHADA pelo usuário, com a profissional e/ou uma terceira pessoa quando esse cuidado a envolve.

No caso de escolha de método contraceptivo, geralmente apenas a mulher comparece à consulta ou ao grupo operativo. Assim, a usuária deve ter informações claras e suficientes para, por exemplo, esclarecer seu companheiro sobre os métodos contraceptivos, as opções existentes, os 
riscos e benefícios de cada um para, após deliberação, decidirem sobre o melhor método.

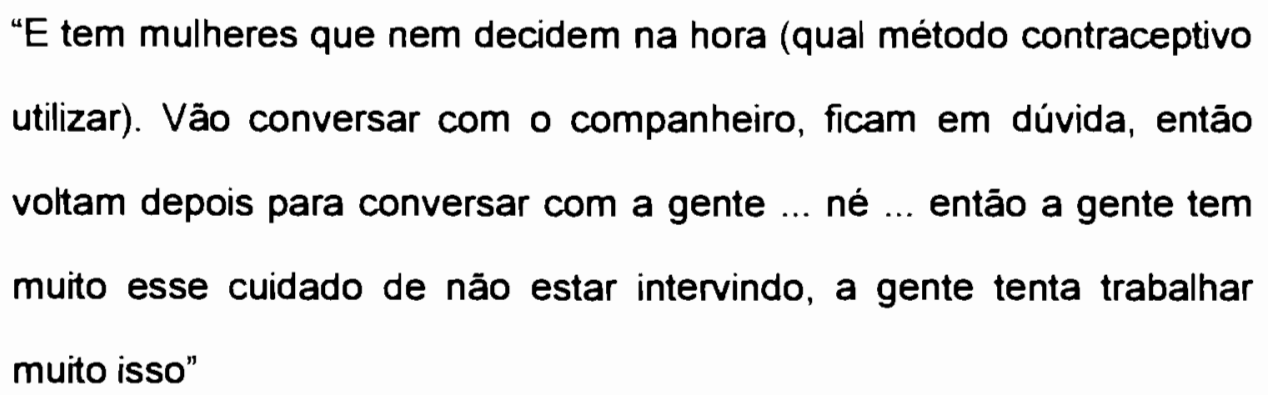

"ela tem que ter informação ... eu acho que ela tem que ter informação. Ela não deve tomar a decisāo (opção por método contraceptivo) sozinha ... se ela tem um companheiro, ela deverá dividir a decisão com ele ... para não sobrecarregar só para ela, terá que ter uma decisão em conjunto. E ter informaçāo ... qualquer que seja a decisāo que ela for tomar, ... como convencer o parceiro a usar camisinha ou nāo, é tendo informação.

É interessante dizer também que afirmam que a decisão depende da relação profissional-usuário, mas, conforme dizem, a decisão do usuário na realidade acaba se restringindo a acatar ou não a orientação dada. Dão grande ênfase à essa relação, no sentido do profissional "conseguir" que o cuidado seja executado, como vemos a seguir:

.... Acho que depende da relação enfermeiro, ou profissional de enfermagem e paciente. Eu acho, para mim .... é uma estrada de mão dupla. Não adianta você só caminhar no sentido profissional, você tem 
que ter a resposta do paciente. Senão o cuidado não vai ser, ...., ou vai ser mal executado, o que muitas vezes é mais desastroso do que se não for executado, né. Então, eu acho que para mim é uma estrada de mão dupla. São os dois caminhos. Depende do profissional, enfermeiro ou a equipe de enfermagem que está orientando esse cuidado, e do próprio paciente. E ai eu acho que essa relação ela tem que estar sempre muito bem afiada para você conseguir que esse ou aquele cuidado seja de fato executado, entendido, o paciente ... enfim ... ser tratado ou querer se tratar."

Ainda nesta unidade temática várias falas se reuniram no núcleo INSTRUMENTOS PARA DECIDIR e incluem temas sobre a competência técnica, informação sobre o usuário e condições materiais.

Em relação à competência técnica, conhecimento científico e experiência profissional, todas as entrevistadas afirmam que é necessário conhecer o problema de saúde apresentado, as opções de cuidado, as recomendações existentes em manuais, normas e rotinas, e aquelas advindas da experiência profissional. A apresentação de opções e as recomendações a serem oferecidas pela profissional têm como requisitos esses três fatores.

Segundo Beauchamp e Childress os padrōes de cuidado incluem conhecimento, habilidades e diligência (1983).

“Então, eu, como sou uma enfermeira do interior, de vivência, o que eu fiz? Mandei ele achar um toucinho, colocar um toucinho no curativo dele e voltar no dia seguinte. Foi ontem. Não teve outra ... Ele percorreu três, 
quatro unidades que o pessoal não soube como resolver e no dia seguinte, .... nós tiramos o berne do ferimento do braço dele simplesmente com um band-aid e um toucinho. Se a gente tivesse enfiado coisas, pressionado ... teria quebrado o bicho. ... quem não conhece o bicho ... não sabe ..."

“é preconizado ... assim .... nesta data é o que está sendo preconizado, né, a utilização de soro fisiológico ... Abolido o povidine, até então, usado em larga escala. ... Então sāo procedimentos de enfermagem que a gente tenta se atualizar na medida do possivel, e fazer o melhor".

"Eu acho que basicamente conhecimentos sobre o problema que você está trabalhando ou orientando, ... eu acho que você tem que conhecer esse problema a ponto de você poder realmente fazer uma recomendação adequada,... que realmente sirva para o paciente. .... Ter conhecimento mesmo, ... E competência acho que também tem que ter".

"a gente tem que seguir os manuais da Secretana, assim, como princípio. Então como é programa, é mais fácil porque você tem os manuais dos programas .... E $\circ$ que ... a gente tenta criar algumas coisas diante da realidade ... se fugir daquela padronizaçāo, o que vai garantir que tenha uma melhor aceitação".

Ainda nesse núcleo, referem ser fundamentais obter informações sobre o usuário e seu modo de vida para a adequação da informação a ser prestada. Procurar saber quais conhecimentos o usuário já tem, fazer uma avaliação sumária de seu estado físico e/ou emocional no momento, obter informaçōes sobre suas condiçōes sócio-culturais, demonstram que elas têm preocupação com o padrão da informação a ser dada, isto é, utilizam o 
chamado padrão subjetivo ou orientado ao paciente (BEAUCHAMP, CHILDRESS, 1994; FORTES, 1994), adaptada à realidade de vida do usuário, ao seu conhecimento prévio sobre o problema e à sua necessidade de informação.

“........ Em relação à auto medicação (insulina), primeiro ver se o paciente tem coragem para se auto medicar, de dar uma picada. Em caso afirmativo a gente vê o local de aplicaçāo, qual a maneira, como homogeneizar o medicamento. Se tem alguém da familia que faça por ele se ele não quiser fazer".

Quando indagada sobre a reação do usuário quanto ao uso de toucinho a enfermeira disse que: "ele também é do interior e entende dessas coisas. Ele falou que já tinha pedido isso mas que ninguém tinha feito. Todo mundo tinha achado um absurdo. Que ele já tinha tomado até Cefamox para aquele ferimento. Imagina ... se não tira o bicho, como é que o antibiótico vai conseguir fazer efeito?"

"existia uma necessidade de limpar aquela ferida porque era imensa .... tinha uma coisa de limpeza, digamos assim, do cuidado em si ... e teria todo o outro ... o pensar ... como esse paciente tomaria um banho, como esse paciente se alimentana, aonde esse paciente dormiria .... Ele è morador de rua...."

“... Então, a forma de você abordar essas questões tem que ser muito simples ... então vou estar usando as palavras que elas conhecem ... vamos estar tentando nos aproximar o máximo possível, .... às vezes a nossa ansiedade está tão grande para passar informação e a gente esquece do resto ... é saber o que ela tem de bagagem em relação ao 
que a gente quer falar .... Senão você vai cansar, vai se cansar, vai cansar o paciente ....

“... o que eu levei em consideração (para solicitar visita domiciliána) foi a questāo social dela, o estilo de vida e até essa parte biológica mesmo ...Me chamou a atenção porque .... me pareceu uma mulher, na época do atendimento, muito frágil. ..... não só físicamente, mas mais socialmente .... E a relaçāo mulher - companheiro, de uma dependência muito grande. Entāo, isso levou a mim e a assistente social a suspeitar de uma violência ... nāo tanto uma violência física, mas outro tipo de violència, de conduta e tal. ..Então, me preocupou como é que ela estaria hoje, porque ela demorou tanto para voltar para fazer esse pré natal. ..."

"No grupo a gente reúne todas as mulheres e ai a gente começa a trabalhar em cima do que elas querem, né. ... O que elas já usaram, o que elas conhecem ... então a gente trabalha em cima do conhecimento delas."

“... as pessoas trazem histórias de colega de trabalho, histórias de mãe, o que acham do método, o que não acham ... A gente tenta desmistificar um pouco algumas coisas que elas trazem ... que tem muito mito, em cima dos métodos e da repercussão deles" (na relação do casal).

"O paciente (portador de HIV) que vai te conduzir, na verdade. Não adianta você ter idéias pré estabelecidas, ações pré estabelecidas. ... . Ele sai de uma primeira consulta com um monte de coisas para você orientar. Primeiro, o resultado do exame é um baque. Você vai ter que estar reforçando aquele resultado, a disponibilidade do serviço para um atendimento ao paciente e os exames que ele tem que fazer para voltar. 
" ... No programa de tuberculose ... - olha, o senhor toma depois do café da manhã ... -, mas que café?, ele toma café?, o que ele está entendendo por café?, é o café preto?, como que é a rotina dele ... assim ... Pela unidade é preconizado que ele tomando as duas medicações em jejum ... a Rifampicina e Isoniazida em jejum, e depois os quatro comprimidos de Pirazinamida após o café da manhã ... Agora, se ele me diz que nāo toma café da manhã ... se de repente ele trabalha de noite e dorme pela manhã ... como que é isso? Então, se você nāo pergunta como é essa rotina do paciente, você pode ter ... você corre o risco de ter uma compreensão errada dessa medicação. Se ele for tomar café da manhã às 4 horas da tarde, como é que vai ficar tudo isso? Então, eu acho que é ouvir, primeiro, como que é a rotina desse paciente e garantir $o$ melhor, dentro das suas possibilidades, a melhor absorção dessa medicação, a melhor aceitaçāo por parte do paciente ... O que ... vai garantir que ele tome essa medicação."

$\dot{E}$ interessante dizer que alguns dias depois dá entrevista em que foi relatado este caso, durante atividade de observação das atividades assistenciais, um usuário, que trabalhava à noite, passou pela pós consulta com a enfermeira, após inscrição no sub programa de controle da tuberculose. Nessa ocasião, como relatado em anexo (Anexo 5), pudemos observar a preocupação da enfermeira na busca de adaptação do cuidado, (tratamento, retornos, exames, etc) à realidade de vida do paciente.

Uma das enfermeiras afirma que por conhecer os usuários há muito tempo, sua forma de abordagem varia de acordo com esse conhecimento. Como vemos na seguinte fala, sua atitude pode variar do respeito à pessoa ao autoritarismo. 
Na área $X, “ \ldots$. como eu já conheço, eu sei todas as formas de falar com as pessoas. Tem umas que eu tenho que falar docemente, explicar. Tem umas que tenho que dar "porrada" mesmo, eu tenho que chamar a pessoa para a realidade, dar bronca, vamos dizer assim, dar dura..."

Outras enfermeiras que também, desenvolvem suas atividades em instituições privadas, com usuários de nivel sócio econômico mais elevado que aqueles atendidos nos CSEs, informam que o conteúdo das informaçōes oferecidas nesses serviços é semelhante, mas que muitas vezes, aprofundam mais as orientações nos serviços privados, já que a clientela tem algum conhecimento prévio e solicita mais informações.

"O conteúdo é praticamente o mesmo. Então assim, a nível de consultónio particular, por exemplo, tem um pessoal que já tem alguma base do processo fisiológico da gestaçāo, da anatomia, .... ai dá para a gente ir até um pouquinho além, de acordo com o grupo, .... Se for um grupo homogêneo, com nivel de informação médio, pode seguir um pouquinho mais. É gostoso, é dinâmico.'

“Então, aqui (no CSE) eu vou pegar o básico. Vou ver o que elas estão precisando ... É o digestivo, é o urinário ....'

"A nivel de consultónio às vezes a gente está falando de fatores endócrinos ... então os hormônios mudam sim, e são responsáveis por isso ... Aqui não precisa disso, eu preciso do básico. Mas o conteúdo é o mesmo, com algumas limitações."

“... o conteúdo sim ... de maneira diferente, .... porque aqui .... eu parto do nada, que elas não sabem nada. Lá ... o nível delas é diferente. Então você pode falar - ah, vocês sabem a anatomia da mama? -, pode até falar em anatomia, a palavra anatomia que elas sabem ... - Ah sim, nāo precisa entrar nesses detalhes de anatomia que a gente sabe Aqui nāo, se você vai falar em anatomia, primeiro que elas nem sabem 
esse termo, - Ah, você conhece como è a sua mama por dentro?, por fora?, você sabe como ela chama?, as partes dela? -, - Não, não sei ..., - Então, vamos começar daí -. E mostro para elas como que é. Então, a informação é a mesma, só que a maneira de se colocar lá e aqui é um pouco diferente pelo nível social delas.'

“.... Usando outros recursos, que aqui também eu não tenho muita coisa, né. E acaba sendo o mesmo ..."

Outra afirma que muitas vezes o usuário não entende as orientações dadas na consulta médica e que ela acaba tendo que reorientálo. Cumprindo seu papel de membro da equipe de saúde que auxilia no "esclarecimento do cliente e família sobre seu estado de saúde e tratamento, possiveis benefícios, riscos e conseqüências que possam ocorrer. (Art. 30 do Código de Ética dos Profissionais de Enfermagem). Por outro lado, como vemos no seguinte discurso, a enfermeira acaba assumindo uma tarefa que não é da sua competência, isto é, esclarecer o diagnóstico médico ao usuário.

\footnotetext{
"é o médico que coloca (o diagnóstico) .... depois ela vai estar passando por mim, e na verdade quando o médico coloca, nem sempre o paciente entende. Tem muitas vezes que aconteceu isso comigo, que numa pós consulta eu levo um susto porque na verdade eu falo - você entendeu o que o médico falou? -, - ah, eu entendi, eu tenho vírus (HIV) mas está tudo bem ... não tenho a doença, está tudo ótimo ... -, aí a gente pára, não pode estar tudo ótimo. - Então, aí você começa a conversar tudo de novo, e você vê que ele não entendeu. Ai você está colocando para ela - pára, pensa - e aí que ela cai na real. $E$ aí às vezes nem nesse primeiro momento cai na real. Ainda demora algum tempo para ele tomar consciência sobre o que é ser portador do virus. Entāo, é complicado."
} 
Para que o usuário participe na tomada de decisão sobre o cuidado, afirmam que a informação ofertada é fundamental. BEAUCHAMP e CHILDRESS (1994) afirmam que o oferecimento de informação e o seu entendimento são elementos necessários para o consentimento esclarecido. Vário autores (BEAUCHAMP e CHILDRESS,1994; DURANT, 1995; FORTES, 1994 ) afirmam que, para dar um consentimento esclarecido, o paciente/usuário deve receber as informaçōes necessárias: natureza de seu tratamento, suas conseqüências, possiveis riscos e a existência de outros tratamentos que aquele apresentado pelo profissional. Estas informações devem ser comunicadas em uma linguagem acessivel e compreensivel para o paciente/usuário. Além disso, o consentimento deve ser dado sem que haja constrangimento por parte de terceiros.

"E ai a gente começa a trabalhar, a gente fala - que método vocês querem que a gente comece -, e ai a gente começa a trabalhar em cima do método que elas querem. Ai depois a gente começa a intercalar, o que elas querem ... e depois o que a gente acha que faz gancho uma coisa com a outra. Então, a gente trabalha a questão do método, uso, como usá-lo, os cuidados e também que repercussão isso tem na relação. E a gente trabalha muito ..."

“... a gente tenta ser .... sempre muito claro, explicar .... É um direito dele saber o que ele tem .... ter informaçāo. A gente tenta usar uma linguagem acessivel, que ele vai entender para que ele não saia com dúvidas .... a gente sempre tenta deixar claro o que é ... se é uma tuberculose, o que é, que precisa trazer quem mora junto para ser examinado, que vai ter que tratar, mesmo que acabem os sintomas, que tem que continuar tratando, senão o bichinho fica mais forte .... demora mais para sarar .... você tenta sempre, né ... 
“... você passa as coisas boas, eu passo no grupo, por que o aleitamento é bom, falo também dos problemas que pode ter, não engano ninguém. pode ter ingurgitamento, pode fissurar o peito ... eu nāo costumo mentir, falo a verdade. Falo que pode ter problemas, mesmo fazendo todos os exercicios que oriento aqui na gestaçāo, tomar sol, fazer isso, fazer aquilo, pode ter bico que vai machucar .... No final ... eu falo ... estou passando conhecimento para vocês ... e a partir desse conhecimento vocês tem livre arbitrio ... ou vocês amamentam ou não. ..., acho que ela tem direitos sobre o corpo dela. Desde que você coloque os riscos e beneficios, ela faz a opçāo dela.

“... eu costumo orientar bem ... o mais simples possivel ... o palavreado mais simples, falar ... mostro ... trago cartazes, explico para elas. Depois passo o video."

As condições materiais, isto é, a disponibilidade ou não de recursos materiais, medicamentos, equipamentos, recursos humanos e físicos acabam influenciando no cuidado e nas decisões. Por exemplo, em alguns casos, a nāo disponibilidade de alguns medicamentos no serviço, acaba restringindo as opçōes apresentadas; em outros, apresenta-se opções que dependem da possibilidade de compra por parte do usuário para que o cuidado seja realizado. Outro exemplo sāo as condiçōes de trabalho: a falta de espaço físico que obriga o atendimento simultâneo de dois usuários na mesma sala, ou o deslocamento para outra que não tem os materiais necessários para o desenvolvimento da atividade; ou ainda falta de tempo para se dedicar ao esclarecimento. Em uma das unidades, o encaminhamento do usuário a outro serviço por falta de equipamento (microscópio), leva a enfermeira a aguardar até 10 dias para a tomada de 
decisão, enquanto que em outra, que conta com o equipamento e pessoal treinado, ela é imediata e permite a seleção de medicação mais específica para o problema apresentado pelo usuário.

“... a gente está contando que o carvão ativado teria que ser prescrito ... A unidade tira isso como uma prescriçāo médica. Então, se ele puder comprar, uma vez que a unidade não dispōe, se ele puder comprar ...."

“.... a nossa primeira opção é usar o Metronidazol que a gente tem aqui, ela não precisa comprar, mas tem outros tratamentos que são mais rápidos, é dose única, que é mais cômodo, mas é caro."

“... essa é uma pós consulta que foi tumultuada, por dois motivos: primeiro pela própria situação, e segundo pela falta de espaço físico ..... tem uma fazendo pós consulta (de paciente portador de DST/AIDS) aqui, tem um (outro) que a gente pede para aguardar (na porta), ou eu pego esse paciente e vou na sala ao lado

“... Às vezes eu preciso de um impresso que eu não tenho lá e venho aqui ... entāo é uma coisa muito truncada, você não tem tranqüilidade para estar trabalhando. $E$ isso irrita muito, porque você já está lidando com uma situação difícil, ... e você tem quebra do seu raciocínio ... nāo tem continuidade muitas vezes daquele processo."

Outro "... dia fui perguntar para um adolescente (que veio procurar preservativos) se ele sabia usar. Ele falou - claro que eu sei usar! - aí eu fui perguntar para ele como é que ele usava e falou - ah, eu sei usar...- mas a gente não tem espaço nem o tempo necessáno para trabalhar (informou anteriormente que foi a um treinamento e que eram necessários 40 minutos para se fazer essa orientaçāo), porque eu acho que nāo adianta você dar preservativo sem onientação. Porque o que acontece na maioria das vezes é o uso incorreto mesmo." 
“... por enquanto a gente está pensando em ter o microscópio e fazer coleta a fresco aqui, exame a fresco. Por enquanto nós nāo temos, entāo o recurso que a gente tem é encaminhar direto para exame (em outra instituição), para fazer bacterioscopia (cujo resultado demora cerca de 10 dias para chegar à unidade) ..."

Uma das enfermeiras cita haver no serviço recursos para o atendimento imediato de carências vividas pelos usuários, e que acabam viabilizando a realização do cuidado.

"Na verdade existe historicamente no setor, bazares e doações .... a gente tem um fundo de bazares anteriores que a gente consegue ajudar o paciente nesses casos (morador de rua com ferida infectada, necessitando de encaminhamento a hospital). Então, pelo menos, para aquele dia a gente consegue fornecer uma alimentação, um lanche, né, ou uma roupa que alguém habitualmente, historicamente já está acostumado a doar, a gente tem um cantinho onde a gente guarda, né ... Fornecemos um lençol (ri) ... que era o que tinha disponivel para ele se enxugar ... e ele conseguiu fazer essa higiene pessoal, se alimentar .... pode ser que numa avaliaçāo mais formal ... isso nāo seja o certo, mas a gente vai ter que entrar ... é uma questāo paternalista, está pegando no colo, não sei quais as críticas que seriam dadas neste caso, mas a gente como equipe de enfermagem, e a médica que atendeu, .... achou pertinente tomar essas atitudes e garantimos algumas coisas .... (também) foi encarninhado para o serviço social, e a gente garantiu as coisas de imediato, porque não daria para ficar esperando essa resposta durante quatro, cinco dias ..."

Esta enfermeira, identifica erroneamente como sendo paternalismo (tomar decisões por pessoa competente para fazê-lo) o assistencialismo praticado pelo serviço, há muitos anos. 


\section{Resultados e Análise}

Outro fator que colabora ou dificulta a tomada de decisão, segundo as enfermeiras, é a disponibilidade ou não de pessoal. Como podemos verificar a seguir, a disponibilidade de equipamento e pessoal devidamente treinado para a realização das diversas técnicas possibilita um tratamento mais específico para o problema apresentado pela mulher, evitando um "desperdício" de recurso terapêutico.

“... Como a gente tem a possibilidade de fazer exame a fresco e o teste de amina (por ter equipamento e pessoal devidamente treinado então a gente nāo entra com toda essa medicação. Trata só o que ela tiver mesmo."

Já a ausência de profissional qualificado e de sistema de referência e contra-referência formalizado, e a angústia da profissional frente aos problemas apresentados pelos usuários de seu serviço, que necessitavam de onientação especifica, levaram a enfermeira a tentar suprir, em parte, essa deficiência ela mesma usando sua capacitação (fez treinamentos e cursos em serviço especializado) e realizando encaminhamentos fora do sistema de referência, e contra-referência com a utilização de artifícios como encaminhar para colega enfermeira que trabalha em unidade que conta com o serviço que o usuário necessita. Identificamos neste caso, a seriedade com que a profissional assume seu compromisso com a saúde dos usuários de seu serviço apesar das dificuldades enfrentadas no setor. A enfermeira se coloca como agente de resolução. A decisão sobre o que fazer e para onde encaminhar é feita por ela. 


\section{Resultadas e Análise}

“..., o centro de saúde não conta com fisioterapeuta, e uma vez que eu estou trabalhando em um programa que é incapacitante, né, que pode gerar incapacidade, o mínimo que eu podia fazer era aprender algumas técnicas simplificadas (em serviço especializado) ... afinal de contas é a área de saber do fisioterapeuta ... mas o que eu puder fazer, uma vez que estou enxergando problemas ... eu tenho que arregaçar as mangas e fazer, né, tentar fazer alguma coisa. A gente não conta com muito apoio para encaminhamentos na área de fisiatria, fisio ou mesmo ortopedia ..... uma vez que não dispomos desse profissional .... é quase medicina por favor."

“.... , eu acho que não basta dar um papel na mão e deixar o paciente se virar sozinho por São Paulo, lá fora. Então, eu tento intermediar .... as unidades que dispõem desses profissionais, e tento amarrar o caso com a enfermeira do local, encaminhando ou via telefone, passando o caso, ou mesmo por escrito, reforçando a necessidade de você ter um acompanhamento desse paciente. Tem muita coisa para ser feita, sinto angústia após 15 anos ... eu acho que é isso que define esse momento profissional, eu acho que ainda tem muita angústia, assim, de não resolver uma porçāo de coisas, mas ainda me resta um certo pique ... (ri) ... que na hora que ele terminar vai ser duro ..."

Na segunda categoria, PRESTAÇĀO DE ASSISTÉNCIA, as falas das enfermeiras focalizam a assistência de enfermagem a individuos, familiares e coletividade e conduta tomadas frente à decisão

Em relação à ASSISTÉNCIA DE ENFERMAGEM A INDIVIDUOS, as enfermeiras informam serem suas atividades assistenciais mais voltadas para o ensino do auto-cuidado, tanto na assistência individual como nas atividades em grupo. Como os usuários dos centros de saúde fazem 
tratamento ambulatorial, os cuidados são, em sua maioria, realizados por eles próprios em seu domicilio. Assim, as enfermeiras enfatizam a necessidade de informar e esclarecer e, quando necessário, demonstrar a técnica.

No caso da assistência prestada diretamente ao usuário, verificamos situações em que essa orientação é feita anteriormente ao procedimento, ou no transcorrer da execução do cuidado, ou após sua realização. Nesses dois casos, a possibilidade de obtenção do consentimento do usuário não existe, apesar de haver o oferecimento de informaçōes.

"Orientei a ela como se faz a ordenha (demonstrando a técnica de ordenha em si mesma). Hoje em dia a orientação é evitar por a mão na paciente, ela mesma deve fazer a ordenha. Ela sabe o quanto está doendo e vai passando a mão, vendo onde está endurecido, faz a massagem e vai retirando o leite."

“... a gente tenta mostrar como está o umbigo, pergunta para ela se a gente pode fazer o curativo com o álcool (e não merthiolate como a usuária vem fazendo) e mostra para ela como se faz. Procuramos falar da experiência do nosso serviço, e que estamos embasados em estudos da Organização Mundial da Saúde e da Secretaria da Saúde."

“... Para que, qual a finalidade dessa vacina (que apliquei), que tipo de reações a mãe pode esperar, que tipo de cuidados ela tem que tomar de acordo com a vacina que foi aplicada e que tipo de ação a mãe tem que ter caso ocorram outras coisas diferentes daquelas que são as mais esperadas." 
Neste último caso, inclusive, informações sobre os benefícios e as reaçōes adversas são oferecidas após a execução do cuidado. A vacinação de crianças é obrigatória em todo o território Nacional (Estatuto da Criança e do Adolescente art. 14) mas não deve prescindir de consentimento para sua realização.

No caso de cuidado voltado para a orientação do usuário, sobre medicação controlada verificamos a preocupação das enfermeiras em esclarecê-lo sobre os cuidados com o medicamento:

"O paciente tem que estar muito bem orientado, o que ele está levando para casa (talidomida)... como ele vai tomar ... aonde ele vai guardar esse medicamento. $O$ médico assina um termo de responsabilidade $e$ ele também está assinando um termo de responsabilidade, quer dizer, na verdade você tem que se dar nessa orientação um pouco mais ... Não é perder tempo ... è ganhar tempo, né, explicando para ele o que ele está tendo em mãos agora para cuidar... Então, para o paciente você explica quantas vezes for necessáno, o que ele está levando."

A mesma enfermeira, quando indagada a respeito da decisão sobre o uso da talidomida, diz:

"como tem um alivio de sintomas ... então ... apesar do susto inicial, aceitam, né, porque resolve o problema."

Neste caso especifico, podernos afirmar que a decisāo do usuário é grandemente influenciada pela sintomatologia apresentada principalmente a dor, que devem ser considerados como possiveis fatores de redução da 


\section{Resultados e Análise}

autonomia o usuário na tomada de decisão, induzindo o usuário a acatar a indicação.

Na pós consulta, as enfermeiras esclarecem aos usuários sobre os exames a serem realizados, o diagnóstico médico, reforçam a necessidade de tratamento. No caso de ações de vigilância epidemiológica, algumas por serem padronizadas por programas, são semelhantes:

“... e ai a gente orienta cada atividade, então, esse exame para que serve, aonde que vai ter que fazer, que dia vai ter que fazer, todos os exames que são solicitados na rotina do programa (DST/AIDS) e são vários num primeiro momento."

“... uma tuberculose, o que é, que precisa trazer quem mora junto para ser examinado, que vai ter que tratar, mesmo que acabem os sintomas, que tem que continuar tratando, senāo o bichinho fica mais forte ... demora mais para sarar ...

"Primeiro oriento sobre o diagnóstico, se entendeu o que o médico disse, que é uma doença que pega, o que aconteceu com ele. Verifico se ele tem condiçōes de receber orientaçōes, se ele consegue assimilar tudo o que estou falando. Se ele estiver apavorado com o diagnóstico (de tuberculose), só falo sobre a regularidade do tratamento, do controle de comunicantes. Se não, faço uma orientação mais detalhada. Pergunto se podemos fazer VD, se ele aceita...."

As enfermeiras tèm como preocupação a explicação dos riscos e benefícios que o cuidado comporta, de forma a instrumentalizar o usuário na sua decisão: 
“ e quando vem o resultado, vem uma DST ou um haemófilos, trichomonas ... daí eu vou dar um tratamento. E eu explico que tem que fazer, porque senão vai ficar sempre com esse corrimento, né, o que vai acarretar no futuro, para ela e para o marido."

"... É como no planejamento familiar, a gente coloca tudo, os riscos e os beneficios e ela decide. Depois das orientaçōes e discussões as mulheres decidem o que vão usar."

“... eu falo sobre aleitamento, ...... eu passo no grupo, por que o aleitamento é bom, falo também dos problemas que pode ter, .... ingurgitamento, pode fissurar o peito ... - você não vai ficar com o peito do jeito que você era mesmo ... . Falo que pode ter problemas, mesmo a gente fazendo todos os exercícios que eu faço aqui na gestação, tomar sol, fazer isso, fazer aquilo, pode ter bico que vai machucar ... então eu costumo não obrigar ninguém. “

Na existência de mais de uma opção de cuidado ou tratamento, apontam aquela que, enquanto técnicas, recomendam ou nāo.

“.... Então, a gente conversa, mostra os riscos, explica o porquê dela não poder tomar pilula tão cedo, sendo tão jovem ... tendo um monte de tempo pela frente ainda ... que não dá para tomar pilula a vida inteira ... você explica, explica ... e ela é uma pessoa que até acaba aceitando, só que naquele momento a experiência que ela teve com aquele diafragma não foi legal, então ela não quer usar, né. Ai você ... não dá para você impor. Tem um limite, tem um limite.

Uma das enfermeiras entretanto, afirma que não oferece certas informaçōes ao usuário por acreditar que poderia levá-lo a parar o tratamento, como vemos a seguir: 
"Só se o paciente perguntar (sobre efeitos colaterais dos medicamentos para tratamento de tuberculose), porque qualquer coisa que tiver, pronto, é do medicamento e acaba parando de tomar".

Deve-se entretanto considerar que, em havendo efeitos adversos da medicação, o usuário também pode vir a interromper o tratamento por não ter informação sobre isso. Acreditamos que, se ele for esclarecido quanto aos efeitos colaterais da medicação e quais as condutas que deve ter frente a eles, será possivel uma maior adesão ao tratamento. A atitude da enfermeira demonstra ser paternalista, isto é de desrespeito à pessoa autônoma, através da omissão de informação para, na sua opinião, beneficiar o usuário.

Além de fazerem orientações para o auto cuidado, demonstrarem como se realiza a técnica que exige cuidados, as enfermeiras demonstram ter preocupação em avaliar a atividade assistencial.

“... dá (o material para fazer curativo em casa), ensina, faz supervisāo, se é um caso que não pode vir aqui a gente vai sempre em casa e dá uma olhada. Começa indo todo dia, passa a ir três vezes por semana, passa a ir duas, uma vez por semana ... até assim, a pessoa acostumar e fazer direitinho, fazer sozinho. Ou se você vê que pode vir aqui, que tem tempo e tal ... você marca um horário, combina direitinho e fica no pé. Ou pede uma visita para ver por que nāo veio ... a gente tenta assim ... orientar para que ela faça o que a gente está pedindo, mas se ela nāo quiser fazer, não tem muito jeito." 
"Quando é aquela paciente que deixa colocar o diafragma, ela mesma coloca o diafragma, coloca certo, não demora para colocar ... não tem dúvida ... essas são tranqüilas, elas se adaptam bem ao método .... Ou então o último recurso dela é esse método, não queria, mas foi indicado porque não tem outro, tem que ser esse ... Então, já não é uma opção dela ... foi uma imposição, uma prescrição....Aí você mede ... manda ela ir para casa, fazer o treinamento ... e marca com 7 ... 10 dias o retorno. Quando elas nāo voltam ... Ou entāo ... se ela vem ao retorno mas fala - olha, não usei... não gostei, não consegui colocar ..."

Em relação à assistência à FAMILIARES E COLETIVIDADE, verificamos que os discursos se referem à preocupação das enfermeiras quanto à extensão de seus cuidados aos familiares e comunicantes, aqui considerados como aqueles com quem o usuário mantém contato íntimo e prolongado, além da coletividade. As enfermeiras entrevistadas desenvolvem suas atividades na área de saúde coletiva, o que influencia suas açōes e atitudes.

Percebe-se, através dos discursos, que as enfermeiras têm uma grande preocupação quanto à prevenção, ao diagnóstico precoce e, quando necessário, ao tratamento dessas pessoas, que - não sendo as usuárias objeto da assistência imediata - são objeto das ações de saúde coletiva. As açōes relatadas são aquelas de cunho educativo, no sentido de levar o usuário a informar, orientar, ou ainda, esclarecer seus comunicantes quanto 
ao seu próprio diagnóstico e tratamento e/ou a necessidade de comparecer ao serviço para exames ou controle.

".... com relação às outras DST, sempre procuro orientar com relação com o que ele está apresentando, o diagnóstico.... a conseqüência que tem para o parceiro, a importância de trazer o parceiro espontaneamente na unidade, que è um dos problemas que a gente tem.

"Nós não convocamos parceiro, a não ser depois de um certo tempo e que a gente tenta trabalhar com o cliente e ele fica relutante. Ai depois a gente começa a forçar um pouquinho. O médico solicita como obrigatório, nós mandamos aerograma e aguardamos ..."

Afirmam também que atualmente os profissionais de saúde têm respaldo legal para a quebra de sigilo nos casos de portadores de HIV que se recusam a informar seu parceiro sobre sua condição, mas dizem que isso é muito delicado, não só para o usuário, como também pode ser perigoso para os funcionários do serviço, como citado por uma das enfermeiras que mais de uma vez referiu-se ao problema da drogadição e da relação de usuários com quadrilhas. Ressaltam que o usuário é orientado a comunicar seu companheiro em um dado tempo que é portador do vírus HIV e que a quebra de sigilo pelo profissional é feita após informá-lo de que o serviço tomará tal atitude se o usuário não o fizer nesse periodo de tempo.

Quando o usuário, portador do vírus HIV se recusa a comunicar o parceiro sobre o fato, "a primeira tentativa, o paciente ele é avisado que ele precisa comunicar o seu parceiro, tem um tempo para isso, claro que não se fala - amanhã traz o parceiro aqui ... -, ele tem um 
tempo. Geralmente é o espaço entre a consulta de hoje e o próximo retorno. Então, se ele não faz isso é obrigação legal do profissional fazê-lo. E ele é informado - você conte, porque senão nós vamos ter que chamar, nós vamos ter que falar -, entāo para evitar esse constrangimento, se você imaginar que são duas pessoas vivendo juntas, se relacionando, que seja feito pelo próprio paciente mesmo. ..... Agora, que deve ser feito isso, acho que deve, porque você tem ... Até há bem pouco tempo atrás a gente não tinha nem posicionamento legal para fazer isso, ninguém respaldava legalmente o profissional de saúde para comunicar seu parceiro que ele era portador de uma doença como AIDS. Mas eu pergunto: por que com outras DST nāo se toma a mesma conduta? É claro, a resposta é: não tem risco de vida, ou não vai matar, ou não vai ... Mas é tāo importante quanto, porque atrás de outra DST pode estar vindo AIDS por tabela, né.

As enfermeiras afirmam que o profissional de saúde tem respaldo legal para isso. Entretanto, devemos esclarecer, que essas enfermeiras se apoiam num parecer elaborado pelo Conselho Federal de Medicina (Resolução CFM 1359/92, art, $2 \oint$ único) que legisla apenas sobre o exercicio profissional dos médicos e não dos profissionais de saúde, inclusive das enfermeiras. Ora, a revelação de diagnóstico médico cabe a esse profissional.

$\dot{E}$ interessante verificar que, nos discursos das enfermeiras, o sujeito da ação "quebra de sigilo", na realidade, não é bem definido. Elas se utilizam de palavras como "nós", "a gente", "profissional de saúde" ou ainda da forma impessoal: "o paciente é avisado", "não se fala". Acreditamos que elas assumem essa identidade coletiva, pelo 0 fato da Vigilância Epidemiológica ser desenvolvida pelo coletivo de profissionais. Elas fazem 
aquilo que é de sua atribuição e da sua equipe: visitas domiciliárias, convocaçōes e o envio de aerogramas, em casos semelhantes ao apresentado, participando no processo de quebra de sigilo, que na realidade é feita pelo médico.

Demonstram ainda, ter preocupação com o respeito à privacidade do usuário do serviço, à sua dinâmica familiar e de vida no que diz respeito à essa quebra de sigilo.

“... ao mesmo tempo que você tem que respeitar a privacidade do paciente, nós temos ... a preocupaçāo, ..., que ele está ... transmitindo (HIV) para seus parceiros ... . E ... nós temos respaldo legal hoje ... para estar convocando esses parceiros. Mas de qualquer forma isso é extremamente delicado. (...) Então, acho que na hora de convocar esse individuo a gente precisa estar avaliando muito bem quem é que nós vamos estar convocando. Nós temos, por exemplo, usuários de drogas, que estão envolvidos com quadrilhas,.... e a gente está colocando em nisco o individuo e a nós mesmos. Nós fazemos algumas vezes visitas ... quando eu trabalhava na infantil, cuidava das crianças HIV, e que eu ia verificar, a mãe que não estava dando $A Z T$, que saía da maternidade e fazia o tratamento incorreto. então nós íamos para orientar. $O$ único objetivo ... não me interessava o que ela estava fazendo ou deixando de fazer, era para ver como estava aquela criança, pela saúde da criança, na puericultura. Entāo a gente ia como saúde infantil. E associava com os problemas da DST aqui. (...). E é uma situação bastante complicada, perigosa. delicada ... tanto para nós como para o paciente, então tem que ser muito bem conduzida.

"Acho que primeiro é um resperto que você tem que ter com o individuo, com a privacidade dele, ... que sempre tem que ser respeitada. Qualquer DST. ... o individuo tem que ter tempo para assimilar aquele resultado, seja lá qual for, e para estar vendo qual é a melhor forma que 
ele vai estar colocando, porque muitas vezes, a maiona, quando não é usuário de droga, é transmissão sexual e de múltiplos parceiros, a maioria. Então, é uma situação que envolve ... relacionamento com familia. Então, você não pode estar invadindo a privacidade dele enquanto individuo e nem desestruturando uma familia por uma decisão precipitada. Então, acho assim, ele tem HIV ou tem sifilis, já tem algum tempo que ele está convivendo com esse problema, e nāo é de hoje para amanhã que você vai querer resolver o problema dele.

Veja-se a reação da enfermeira, diante de um caso de usuária (com aproximadamente 60 anos de idade) com exame feito à sua revelia em outro serviço, com a anuência de familiares (já que a usuária estava inconsciente), que teve como resultado HIV positivo. Os familiares sabem do resultado há dois meses, acompanham-na em consultas na unidade mas nem eles, nem o serviço em que foi feito o exame comunicaram a ela qual o seu real problema de saúde:

"Ai eu fico perguntando - é importante ela saber que ela tem o vírus agora?, para ela? -. Tem o direito de saber, a gente sabe que ela tem o direito de saber. Então, precisamos ver como vamos estar colocando isso para ela. Ai eu falei para ele (o filho da usuária) - você tem mais um tempo para pensar, com calma, porque eu vou ter que marcar um retorno para ela ...."

A enfermeira se indaga quanto ao direito de informaçāo da usuária e afirma que ele deve ser respeitado. A falta de informação impossibilita uma assistência mais completa e a busca de comunicantes. 
No seguinte discurso, a enfermeira afirma que, no geral, se aponta o setor saúde como o responsável pela prevenção de algumas doenças transmissiveis e que existe uma responsabilidade do portador da doença no processo de epidemia, mas que essa responsabilidade não é sentida por ele. É interessante dizer, que ao orientar o usuário sobre essa responsabilidade, as formas de se prevenir a propagação da doença, a profissional estará agindo de forma a proteger a família e a comunidade, isto é, seguindo o principio da nāo maleficência.

“... num pnmeiro momento, o mais importante é ele estar consciente do resultado (HIV positivo) e ... qual o seu papel frente à família dele e a uma comunidade, qual a responsabilidade dele. $E$ individuo muitas vezes ... porque a gente deixa a responsabilidade muito em cima da saúde, todos os aspectos preventivos, campanhas, tudo isso ... mas o individuo eu acho que ele não sentiu ainda qual o peso da responsabilidade no processo de uma epidemia. Ele não sentiu isso..."

Em um outro caso. o não tratamento do comunicante, por recusa dele, teve como conseqüência o surgimento de complicações ginecológicas na usuária do serviço, uma jovem de 18 anos, o que levou a enfermeira a agir de forma beneficente tanto para com a usuária do serviço como para seu comunicante, ao utilizar argumentos mais incisivos, mostrando a gravidade das conseqüências do seu não tratamento:

“... o parceiro levou mais um ano para tratar. Porque eu tive que chegar

e falar - olha, ele vai ter câncer ... (grifo nosso)- ele vai ter câncer ... 
se não tratar vai ter càncer -, assim, tive que chegar ao extremo ... para ver se ele tratava, porque ela tratava e ele nāo ia ... Essa paciente está sendo acompanhada atè hoje, tem o Papanicolau alterado, a biopsia alterada ... com Papanicolau ... classe NIC 2, com 18 anos ... Agora, com ele foi imposição mesmo, ... ela vinha ... nunca faltava ... mas o marido, nem para conversar. ... Depois de quase um ano, ele foi no local de referência e tratou. Mas ela, continua "encacada..."

O seguinte caso ilustra bem a preocupação da enfermeira com a saúde de familiares e a coletividade:

- ... tinha uma profissional do sexo que optou pelo diafragma ... e eu fiquei num dilema imenso. Coloco ou não coloco?, mas é um direito dela ... - não, mas não é ... e como é que eu faço? -, coloquei ... mas .... fiz uma ladainha com ela .... expliquei ... - olha, nāo è aconselhável esse método para vocè, mas é uma opçāo tua, mas vocè vai ter que usar preservativo junto ... - , e ela fazia uma miscelânea, usava anticoncepcional injetável, diafragma e preservativo, que não queria engravidar de jeito nenhum. Mas mesmo assim o diafragma não era indicado para ela. Mas ela usou direitinho, foi assim ... foi uma das únicas que voltava, quando marcava retorno para avaliaçāo

“... E até eu falei com ela - pelo menos protege seu colo do útero. diminui a incidência de ter câncer de colo de útero, mas de DST não protege - Mas .... ela queria um método que ela pudesse usar com o companheiro dela. Então, com o companheiro ela não usa camisinha ... ela usa no trabalho."

Neste caso em particular, é interessante notar que a enfermeira disse estar diante de um dilema, a usuária, uma profissional do sexo, quer utilizar um método contraceptivo que apesar de eficiente na contracepção, não o é para a prevenção de doenças sexualmente transmissiveis às quais 
ela está exposta em sua atividade de trabalho. $E$ interroga, expondo o conflito entre direito individual de escolha da usuária e as conseqüências dessa decisāo para a sua saúde e do conjunto de pessoas que estariam exposta a DST no caso dela adquiri-las: - "Coloco ou não coloco?, mas é um direito dela ... - não, mas não é ... e como é que eu faço?" - A enfermeira, então, apresentou a ela os problemas de sua opçāo, ou como ela mesma disse: “.... fiz uma ladainha com ela ....", e diante de sua insistência, fez a medida do diafragma, orientou-a sobre o seu uso e posteriormente fez avaliaçōes sobre a sua utilização.

Podemos notar também uma certa resignação em sua fala diante da opção da usuária quando diz "- pelo menos protege seu colo do útero, diminui a incidência de ter câncer de colo de útero .... mas de DST não protege -.", isto é, o método escolhido protegeria a usuária de um dos vários problemas a que estaria exposta em sua atividade laboral. Somente ao final, a enfermeira afirma, em tom aliviado, que a usuána a informou que optou por tal método contraceptivo para uso nas relaçōes com seu companheiro fixo.

No seguinte caso em que um pai se recusa a vacinar seus filhos, porque segundo ele, "Deus protege", a enfermeira afirma ser esse um dos piores argumentos para a recusa da vacinação:

"Mas eu já tive um pai aqui que decidiu por não vacinar seus filhos. E ele me ofereceu um argumento - que Deus protege - , era um argumento religioso. Para mim, .... das negaçōes a vacinaçāo, esse é o argumento mais dificil de ser derrubado, e ele tinha dois filhos e eu não consegui vacinar esses dois filhos até hoje.... Porque Deus olha, Deus protege, e Deus vai impedir que esses filhos dele adquiram doenças 


\section{Resultados e Análise}

preveniveis pela vacinação porque Deus olha. Não, esse argumento é imbatível, é imbativel. É claro que .... se eu conseguisse fazer uma atividade coletiva e vacinar esses filhos, eu vacinaria. Mas se o pai está do lado e diz - não vacino, eu não quero que a senhora vacine -, aí não vacino, eu não posso vacinar. "

Ora como podemos observar, não foi apresentada fundamentação religiosa para essa recusa. Aparentemente, o argumento tem um componente mágico, diferentemente do que ocorre na recusa dos Testemunhas de Jeová que têm um fundamento religioso para não aceitarem a transfusão de sangue (Souza \& Moraes, 1998). O principio da autonomia prevê que as decisões devem ser tomadas livres de coerção, ou de controle de terceiros. Beauchamp e Childress (1989: 68), afirmam que "as pessoas podem exercer sua autonomia escolhendo se submeter à demandas autoritárias de uma instituição ou à tradição. Elas exercitam sua autonomia aceitando a legitimidade da instituição ou da tradição como uma fonte de linha a seguir". Assim, torna-se necessário verificar se a decisão tem por base a intencionalidade e o entendimento do usuário e qual a influência de sua crença na decisão.

Neste mesmo caso, a enfermeira, preocupada com o fato das crianças não serem protegidas contra doenças preveniveis por vacinas, afirma que poderia vir a vacinar as crianças em uma situação em que este pai não estivesse presente para recusar, num claro desrespeito ao pátrio poder. Apesar da legislação vigente no país (Programa Nacional de 
Imunização e Estatuto da Criança e do Adolescente ${ }^{14}$ ) determinar a vacinação obrigatória das crianças contra as doenças relacionadas pelo Ministério da Saúde, neste caso, por serem menores de idade; cabe aos pais, que têm a sua tutela, zelar por seu bem estar e tomar as decisões que digam respeito à sua saúde, e não à profissional de saúde.

Duas das entrevistadas relataram casos que surgem com certa freqüência nas unidades, 0 abandono de tratamento de doença de notificação compulsória, cujo controle é funçāo do Estado. (No caso especifico apresentado, os medicamentos utilizados no seu controle, inclusive, não são comercializados, mas fornecidos pelo Estado aos serviços públicos).

A primeira apresentou o seguinte caso:

"Temos um caso de uma mulher, com BK positivo, mãe de duas crianças que desistiu do tratamento. Ela já fez quatro tratamentos. $O$ antibiograma está OK, só está resistente a um medicamento. Ela já fez tratamento com estrepto(micina), com amicacina...já foi ao (Instituto) Clemente Ferreira..., foi dada uma conduta lá. mas ela desistiu. Ela deveria ter sido intemada, mas não quis por causa das crianças, ela não tem quem possa ficar com elas. Procuramos conseguir uma internação para ela no Hospital. Conseguimos, mas ela acabou desistindo.

Demos alta por abandono no papel, mas a gente continua insistindo ... tem uma hora que o paciente se cansa e acaba vindo.

\footnotetext{
${ }^{14}$ Lei 8069 art 14 parágrafo único - É obrigatória a vacinação das crianças nos casos recomendados pelas autoridades sanitárias. (Brasil, 1991)
} 
Já foi tentado até o Juizado de Menores, porque ela continua com BK positivo e contaminando as crianças. Ela recebeu a assistente social com uma faca ... Onde ela mora o ambiente é muito pesado ... é um ponto de venda de drogas...

Ela também tem medo de perder o emprego. Em uma das casas de familia em que ela trabalhava, a patroa veio aqui, xingou a gente, disse que temos a obrigação de informar, e acabou mandando ela embora."

Neste caso, verificamos que se procurou outras possibilidades de tratamento, inclusive com garantia de internação em hospital especializado, o que também foi recusado pela usuária, uma vez que acarretaria, obrigatoriamente, o afastamento de seus filhos. A preocupação com as crianças, filhas da paciente, expostas ao contágio, dada a positividade dos exames e a resistência do bacilo a um dos medicamentos, acabou levando o serviço a procurar um aliado legal, o Juizado de Menores, que, no julgamento do serviço, poderia ajudar a encontrar meios para possibilitar o tratamento em unidade de internação e conseqüentemente afastá-las de fonte de infecção tuberculosa . A visita da assistente social daquele órgão foi mal recebida pela māe, que inclusive a ameaçou fisicamente. (Não podemos afirmar categoricamente, mas acreditamos que ela se viu na possibilidade de perder a guarda das crianças)

Verificamos que há um conflito entre a decisāo da usuária e os princípios da beneficència, isto é, curá-la, e da não maleficência, isto é, evitar a contaminação das crianças e se quisermos incluir, das pessoas que residem na casa em que ela trabalha, por bacilo resistente à medicação. 
É importante dizer que, segundo a enfermeira, este é o quarto tratamento de tuberculose a que a cliente está se submetendo no serviço, inclusive com a utilização de esquema de tratamentos diferentes, e que ela foi ao serviço especializado para o qual foi encaminhada. Desta forma, não podemos afirmar que a causa do abandono de tratamento possa ser atribuída à falta de vontade da usuária em se tratar, ou ainda à falta de compreensão das orientações dadas nos serviços de saúde.

Neste caso, em particular, podemos dizer que, no mínimo, por se tratar de mulher, chefe de família, que aparentemente não conta com familiares, nem com uma rede social de apoio para cuidar de suas crianças, tanto no aspecto fisico-psíquico como no material, o seu afastamento, como pretendido pelo serviço, para tratamento tem conseqüências sociais e emocionais para esse núcleo familiar.

Como dito anteriormente, para que uma decisão seja autônoma, é necessário que haja intencionalidade, entendimento das opçōes existentes e liberdade de controle ou constrangimentos impostos por terceiros. Ora, neste caso, a usuária tem um fator social importante que condiciona sua decisão. Diante do quadro que se apresenta, a usuána decide abandonar o tratamento. Tomando a definição de autonomia dada por Beauchamp e Childress (1994) apresentado no referencial teórico, podemos dizer que a usuária fez uma "apreciação pessoal das possibilidades futuras e em função de seu próprio sistema de valores" tomou uma decisão autônoma contrária à vontade dos profissionais de saúde, que desejam que ela se trate. 
Em nosso país, a norma de controle da tuberculose prevê a alta por abandono de tratamento a usuários que deixem de "comparecer à unidade, por mais de 30 dias consecutivos, após a data aprazada para o seu retorno" (BRASIL, 1995). Em alguns serviços, mais preocupados com o controle da doença, como é o caso do serviço em que a enfermeira trabalha, procura-se fazer esquemas de controle de tratamento como a medicação supervisionada, em que o paciente comparece ao serviço dianiamente para tomar a medicação, ou como disse a entrevistada, apesar de dar alta por abandono de tratamento (porque, segundo a enfermeira, é necessário dar alguma informação sobre o caso ao sistema de vigilância epidemiológica), continua-se insistindo, apesar da decisão da usuária, até que ela se cansa e comparece ao serviço. É interessante dizer que essa estratégia utilizada pelo serviço não muda em nada a realidade de vida da usuária. O condicionante social para a decisão de abandono do tratamento continua presente. Agindo dessa forma, a solução para este problema depende tão somente da usuária e não do serviço, ou da sociedade como um todo.

É interessante, verificar neste outro caso, em que a enfermeira informa:

".... . paciente alcoolista, ele desiste mesmo (do tratamento de tuberculose). Eu falo ... - é o limite do serviço, ninguém aqui é polícia.."

Ao afirmar que: "é o limite do serviço, ninguém aqui é polícia", a enfermeira demonstra que o serviço tem limitações diante do abandono de tratamento por parte do usuário por condições psico-sociais e identifica o ser polícia com a repressão, a coerção, a proibição, etc. Ora, o chamado poder 


\section{Resultados e Análise}

de polícia no setor saúde, geralmente é identificado com as ações de Vigilância Sanitária, que tem o poder de penalizar. Entretarito, algumas açōes de Vigilância Epidemiológica se enquadram perfeitamente na noção de policia dada por SHUQAIR (1996: $8-9)^{15}$, quando falamos de medidas de isolamento, quarentena, notificação compulsória, exigência de utilização de cinto de segurança, etc.

O núcleo CONDUTA FRENTE À DECISÃO, comporta duas situações: apoio à decisão tomada, e conduta frente à recusa ou decisão diversa da recomendada pela enfermeira.

No primeiro caso, a enfermeira oferece mais informações relacionadas à opção do usuário, como vemos a seguir.

“... se você quiser amamentar, você me procure que eu vou dar as orientaçōes. E se você não quiser amamentar, aí também procure a gente. Porque ai a gente vai onientar qual é o leite, como é que vai fazer com a mamadeira ... como você vai limpar, esterilizar, preparar ... qual o leite que você tem que dar quando o recém nascido é pequeno ... ."

Diante da recusa em seguir orientação dada, ou decisão por opção diversa da indicada pela profissional, procuram investigar a causa de tal opção.

\footnotetext{
15 "a Policia é considerada uma função do Estado que visa pôr em ação limitaçōes que a lei impōe à liberdade dos indivíduos e dos grupos, para salvaguardar a manutenção da ordem pública, em suas várias manifestaçōes: da segurança das pessoas à segurança da propriedade, da tranquilidade dos agregados humanos à proteção de qualquer outro bem
} 
No caso de usuário que insiste em usar mercúrio cromo em curativo, a enfermeira investiga: “ ... por que será que ele passa o mercúrio? Será que ele ganha mercúrio?, será que ele tem o mercúrio em casa? Depois de você apurar tudo isso, né ... eu acho que ... a decisão é dele ... se ele estiver consciente que ela está utilizando uma coisa que ... pode até fazer mal ..."

"Tem muita gente que a gente sabe que não trata. Volta ... em pouco tempo ela volta com a mesma queixa. Você pōe na mesa (ginecológica) de novo ... e faz o teste de amina e o exame a fresco. ... a gente sabe que algumas não fazem o tratamento certo ... que o parceiro não trata, que nāo usa a camisinha. Entāo, a gente senta de novo e tenta entender o por que ela não fez aquilo ... Se ela não entendeu como era o tratamento, se o parceiro dela falou que nāo vai tratar e não adianta ... E ai não adianta ela tomar o remédio, se ele não tomar, que ela vai pegar de novo. Se ela tratou mas não conseguiu tomar a medicação no tempo que era para tomar ... deu dor de estômago, desistiu"

“mas ela disse que o diafragma machucava ... então eu não sei, sei o que medi ...era daquele tamanho, não tem menor...Mas voltou com a mesma queixa, que estava machucando, que estava incomodando, que não gosta. ...E ela colocava certinho porque ela já vinha com ele colocado, eu examinava e estava no local certo ... então relutei, relutei ... até que - então não vamos usar o diafragma -, passou a usar camisinha."

Diante da recusa em seguir as orientaçōes para o auto cuidado ou se submeter ao cuidado a ser prestado, as entrevistadas procuraram reorientar o usuário:

tutelado com disposiçōes penais", prevenindo perigos e danos ao bem comum," entre os quais está a saúde pública. 
“... ai você tem que gastar o verbo bastante com ele, convencer ele que precisa retirar aquele calo (no pé de usuário portador de hanseniase) de um raio $X$ do osso, ele precisa procurar um serviço, porque senāo daqui a pouco está sem o membro. ... Você tem que expor as dificuldades para ele, ele tem que estar consciente ... dos riscos dele não fazer o que você está falando"

“... se é tóxico (solução de uso tópico em curativo), se produz uma toxidade ... você está dizendo isso e mesmo assim ele está utilizando, ele também é responsável, eu acho que você tem que ter certeza que você esgotou seu recursos na orientaçāo. Você vai abandoná-lo ou vai puní-lo ... ou vai encarcerá-lo?, não, né ... de repente ... eu acho que você pode frisar diariamente que aquilo está errado ...

"Eu já fui cobrir foco de sarampo ... numa obra. O rapaz subiu na obra e quase caiu lá de cima, para não tomar a vacina ... eu mandei avisar que eu não vou dar, se ele não quer. Eu vou explicar que o risco dele ficar doente é razoável, porque ele dormia no mesmo cômodo do outro. Que se ele ficar doente como o outro ficou, vai ser intemado e ele vai tomar muito mais injeção do que essa daqui, que é descartável, a agulha é pequena, é rapidinho e tal. Ele não quer, ele não quis ... esse moço não quis ... escrevi lá, tinha um comunicante que se recusou. Porque é o limite até onde eu posso ir, entāo eu procuro manter um pouco o pé na realidade."

Este último caso é interessante pois o rapaz em questão, "subiu na obra e quase caiu lá de cima, para não tomar a vacina ...", isto é, colocou-se em risco para não tomar a vacina. Havia então dois riscos ou danos a serem evitados: o acidente ou o sarampo. Considerando que o primeiro pode ter conseqüências imediatas mais graves, a enfermeira concorda em não vaciná-lo após orientá-lo sobre os riscos de ter o sarampo. 
Se, tendo reorientado o usuário ele continua optando por conduta diferente da indicada, as enfermeiras acatam a decisão do usuário e demonstram ter preocupação em documentar tal fato no prontuário ou em outro documento (relatório de visita a instituição, por exemplo), achando que se isentará de resporısabilidade das corıseqüências da opção do usuário.

“... um recurso que eu tenho também é o prontuánio do paciente. É único documento que a gente tem. Eu ponho - paciente se recusa em aceitar as orientaçōes prestadas por causa disso, disso e disso ... -, quer dizer, se ele tiver alguma complicação é por causa dele, não por falta de orientação."

"Mas se o paciente acaba sendo incisivo, muito, na conduta dele ... eu deixo ele tomar a decisão dele. Depois ele vai retornar com um quadro pior, isso com certeza. $E$ ai, infelizmente, nesse momento, ele vai ter uma escuta em relação aos nossos procedimentos de forma diferente. Infelizmente é assim."

“... se ele compareceu aqui e ele tem um prontuário, uma coisa onde se registre, isso (recusa tomar vacina antitetânica) é anotado. Se ele não tem, não se abre um documento para isso, mas ele recebe a orientação, e a decisão de se submeter a um tratamento ou não é sempre do paciente, eu acho. Então, agora ele vai saber que vai correr o risco de adquirir uma doença como tétano ou outra qualquer."

Ora, o fato de registrar a recusa, principalmente de tratamento de doenças de notificação compulsóna, de vacinação obrigatóna em documento não isenta a os profissionais que desenvolvem seu trabalho em serviços de saúde coletiva da responsabilidade ética frente à saúde da comunidade, apesar da Norma de controle da tuberculose prever a alta abandono. 
Às vezes, a opção feita pelo usuário é contra-indicada pela enfermeira devido aos riscos apresentados pela opção tomada e necessita de acompanhamento de outro profissional, para o qual a enfermeira o encaminha, como vemos a seguir:

\begin{abstract}
"Tem mulheres que acabam optando por anticoncepcional (oral) ... mas é hipertensa, então ai assim - eu não aconselho vocẽ a usar esse método, eu não te prescrevo ... Se você quiser você procura outro profissional -, e tento explicar o porquê daquilo, a importância daquilo. Às vezes tem mulheres que insistem - então, você vai, procura o ginecologista (do CSE), a responsabilidade agora ali é tua ... -, então tem algumas que a gente tem que ser mais ... enfatizar mais. ....
\end{abstract}

\title{
Quanto ao CONHECIMENTO O CONSENTIMENTO
}

ESCLARECIDO, última questão elaborada nas entrevistas, verificamos que as enfermeiras desconhecem o termo, mesmo nas unidades em que existem formulários para a obtenção de consentimento para a realização de pesquisa. Algumas tentaram dar uma definição partindo do significado das palavras:

\footnotetext{
"imagino que seja mais ou menos isso ... (ii) ...que a gente está conversando ... de você estar orientando e esclarecendo a coisa para a pessoa, para ter o aval dela que vocẽ pode fazer aquilo com ela ... sei lá ..."

“... pelas palavras eu imagino que deve ser um documento ... que você estaria obtendo do paciente o conhecimento para o tratamento...."
}

Outra enfermeira, que desenvolve açōes de Vigilância Epidemiológica, identificou o termo consentimento esclarecido ou informado 
como o termo de responsabilidade que as mulheres em idade fértil assinam antes de tomar a vacina contra rubéola:

“... a gente faz um termo de responsabilidade, né, que antes a gente explica o que é e no próprio termo também a gente escreve todas as possibilidades de erro, de erro nāo, de gravidade, .... quais são os riscos de uma possível gravidez ..."

Há ainda quem nunca ouviu falar, nem leu sobre o assunto, e uma das enfermeiras que disse desconhecer o termo, informou estar participando de pesquisa envolvendo usuários e que os mesmos preenchem um questionário e assinam documento concordando em participar da pesquisa:

“...normalmente a gente explica todo o procedimento do Papanicolau. Depois se fala um pouquinho de DST, ... que tem aumentado muito o número de AIDS em mulheres, e que quem quiser, tiver vontade de fazer (o exame para HIV), tiver algum problema, e quiser conversar com a gente depois ... que não precisa falar ali na hora, mas pode falar dentro do consultório. $E$ tem também um trabalho de DST que eles estāo desenvolvendo aqui. $E$ faz parte do trabalho estar solicitando esses exames.... Tem um questionário, elas assinam que estão concordando em preencher o questionário e em colher o material ... mas isso é um trabalho recente, tá. Antes disso a gente já fazia oferta dos exames e a gente deixa em aberto."

Apenas duas enfermeiras, que desenvolvem suas atividades no CSE que solicitou o projeto de pesquisa para submissão à comissão de ética médica, afirmaram conhecer o termo e relataram ter participado em atividades de pesquisa envolvendo usuários do serviço. Uma enfermeira que realiza atividade de campo, preenchendo questionários, orientando e 
acompanhando os casos, afirma não haver diferença no atendimento das mulheres que não participam da pesquisa, a nāo ser na necessidade de assinar o termo de consentimento. Outra afirma estar participando da elaboração de termo de consentimento para a realização de outra pesquisa na unidade.

“ na pesquisa que eu faço, tem um consentimento informado, que a gente fala ... eu explicava, falava o nome, o que era e ela tinha opçāo de participar ou não, de querer participar ou nāo. Então ela assinava . Informava o que é o diafragma, que ele nāo protege contra DST e AIDS, que tem que usar camisinha ... Como que se usa, quando procurar a gente. Que o diafragma era de graça, a consulta era de graça ..."

“ como a gente tem bastante pesquisa aqui, quando se trata de pesquisa a gente sempre pede o consentimento do paciente. ... Agora, essa pesquisa da violência que vai entrar,... a gente estava justo discutindo consentimento. Foi uma das coisas que a gente redigiu na segunda, explicando bonitinho o que era e tal."

Desta forma, do total de enfermeiras entrevistadas, apenas duas souberam informar o que é consentimento esclarecido relacionando-o à obtenção de consentimento para a realização de pesquisa, nunca para a assistência. Uma delas participa de atividade de campo de pesquisa, desenvolvendo atividades assistenciais junto a mulheres e afirma que a única diferença no atendimento das mulheres que participam da pesquisa é o preenchimento de impresso próprio da pesquisa: 
"nāo têm diferença nenhuma entre uma paciente que mediu o diafragma na pesquisa e outra fora da pesquisa. A diferença é que tem um papel que tenho que preencher e mandar. A que não está na pesquisa vai voltar do mesmo jeito, vou falar as mesmas coisas, vai ter o diafragma de graça do mesmo jeito, geléia ... tudo que precisar."

As enfermeiras, sujeitos desta pesquisa, embora nāo inquiridas diretamente no inicio da entrevista sobre o conceito que tinham do termo "consentimento esclarecido" se aproximam, de alguma forma da definição desse conceito ao tecer comentários significativos nos relatos de intervenções cuidativas no cotidiano de seu trabalho.

Através dos discursos e da observação participante, verificamos que elas desenvolvem suas ações orientadas para o respeito ao direito de participação do usuário nas decisōes sobre sua saúde. Oferecem informaçōes sobre o problema de saúde apresentado, opçōes de cuidado para deliberação e decisão.

As informações são oferecidas seguindo o padrão subjetivo, isto é, adaptado a cada usuário. As opções apresentadas para deliberação foram, no geral, aquelas previstas em programas e protocolos, como por exemplo: métodos contraceptivos, medicação para tratamento de leucorréia. Em muitos casos, nāo existia outra opção, além de aderir ou nāo ao tratamento.

Em algumas situações, a enfermeira oferece as informações somente após a realização do cuidado. Apesar de informar sobre o que foi feito, porque, qual o benefício e quais reações adversas devem ser 
esperadas, não houve possibilidade do usuário solicitar mais informações nem participar da decisão. É o caso da vacinação, que sendo obrigatória, faz com que a enfermeira prescinda do consentimento, já que os responsáveis levaram seus filhos à unidade especificamente para tal. O que não seria correto do ponto de vista ético, já que após as informações, haveria a possibilidade dos pais fazerem opções diferentes daquela que foi realizada, como por exemplo, não aplicar todas as vacinas no mesmo dia, mas com intervalos. 
Conclusães

EibliotecalcIR

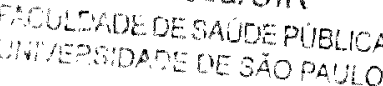




\section{CONCLUSÕES}

Em sintese pode-se apreender da análise dos resultados que todos os sujeitos, embora não inquiridos diretamente no início da entrevista sobre o conceito que tinham do termo "consentimento esclarecido", se aproximam, de alguma forma da definição desse conceito ao tecer comentários significativos nos relatos de intervenções assistenciais no cotidiano de seu trabalho.

As enfermeiras dos Centros de Saúde Escola demonstram, em suas falas, que respeitam as normas básicas do consentimento esclarecido no Código de Ética dos Profissionais de enfermagem em vigência:

Prestar adequadas informações ao cliente e familia a respeito da Assistência de Enfermagem, possiveis beneficios, riscos e conseqüências que possam ocorrer (Art. 26);

Respeitar e reconhecer o direito do cliente de decidir sobre sua pessoa, seu tratamento e seu bem estar. (Art. 27); e

Colaborar com a Equipe de Saúde no esclarecimento do cliente e familia sobre seu estado de saúde e tratamento, possiveis beneficios. riscos e conseqüências que possam ocorrer. (Art. 30)

que, por sua vez, seguem as diretrizes dadas pela legislação vigente no país (Anexo 6)

Pode-se deduzir do exposto que as profissionais entrevistadas praticam atitudes éticas que correspondem positivamente ao "consentimento esclarecido", muito embora, a maioria não saiba conceituar teoricamente, partindo para a sua definição através da interpretação das palavras "consentimento" e "esclarecido", identificando-o com termos de 
responsabilidade (na vacinação) ou então com o termo de consentimento para realização de pesquisas.

Assim, as enfermeiras, na sua relação cotidiana com os usuários, acabam contrariando nosso pressuposto inicial de que

os profissionais de enfermagem têm desenvolvido açōes junto aos usuánios, de forma impessoal, padronizada, autoritána e paternalista, voltada para a patologia-sintomatologia, em detrimento dos aspectos psico-sociais das pessoas, desconsiderando-as do cuidado prestado"

Respeitam portanto, o preceito do "consentimento esclarecido", objeto de estudo da atual investigação. O que, nos parece bastante gratificante. Entretanto, não podemos generalizar estes achados para o conjunto de enfermeiras que trabalham em outros locais de trabalho na área de saúde coletiva, já que optamos por entrevistar apenas enfermeiras de CSE.

Acreditamos esta postura ética se deve ao fato das enfermeiras entrevistadas comporem um grupo de profissionais que trabalha em unidades ligadas a unidades de ensino em que a questão da cidadania sanitária é uma preocupação. Foi nessas instituiçōes que se discutiram as bases da Reforma Sanitária, que entre outros pontos, previa a participação popular. Algumas delas, inclusive, já desenvolviam suas atividades nesses serviços naquela época (meados da década de 80 ). Além disso, a integração entre as unidades de ensino e os CSEs permite a troca de experiências e saberes, possibilitando o aprimoramento do profissional do serviço.

Considerando que a existência de opções é um dos requisitos para o exercicio do consentimento esclarecido, observamos que as 
apresentadas para os usuários são aquelas estipuladas em programas, rotinas e protocolos. A atividade assistencial nos serviços caracteriza-se por essa normatização dada pelos programas pré estabelecidos. A autonomia profissional transparece nos momentos em que não existem estes instrumentos, e as opçōes apresentadas são as advindas de seu conhecimento e experiência.

Sendo agentes que implementam políticas públicas, elaboradas pela sociedade e expressas na legislação vigente (Constituições Federal e Estadual, Lei Orgânica da Saúde, Código da Saủde, Normas específicas de Vacinação, controle de tuberculose, hanseniase, etc), têm por obrigação cumprí-la. Assim, verificamos através dos discursos das enfermeiras, que há um conflito entre o respeito à decisão autônoma e a justiça, no que se refere às decisões individuais que tèm repercussōes na saúde de terceiros, de difícil solução ou ainda, sem solução. Algumas aparentemente se conformam pois segundo elas, "não somos policia" outras demonstram certa angústia, uma sensação de impotência por não ter condições de trabalho que possibilitem a realização de visita domiciliar, tratamento supervisionado ou ainda por desconhecer instrumentos outros que aqueles contidos nos programas e normas especificas da saúde (Programa de saúde da mulher, Programa de DSTIAIDS, Norma de controle de tuberculose) para a proteção dessas pessoas. Assim, o respeito às normas existentes fica claro quando dão a chamada "alta por abandono" no caso de decisão autônoma de não se tratar de tuberculose, porque é necessário dar um "final" para o caso após o periodo previsto para o tratamento. Observamos em uma das unidades, entretanto, que devido ao compromisso com a saúde pública, sua "missão", em uma das unidades, as enfermeiras se mostraram criativas, buscando outras formas de obtenção da adesão ao tratamento, muitas vezes não muito 
efetivas como: acionando o Juizado de Menores e continuando a insistir, como diz uma das enfermeiras "até que ela (usuária) se cansa" e comparece ao serviço para tratamento.

Desconhecem outros aliados institucionais, como por exemplo, o Conselho Municipal de Saúde, a Promotoria da Infância e da Juventude, a Justiça ou mesmo Organizações Não Governamentais que poderiam ser informados sobre a situação, possibilitando a participação nas discussões sobre a elaboração de políticas públicas saudáveis, a formação de redes sociais de apoio, etc.

O ensino da Enfermagem de Saúde Pública em todos os niveis deve ter como preocupação o direito a um cuidado humanizado, respeitando o direito do usuário em ser esclarecido sobre suas condições de saúde e a existência de alternativas de cuidado, mesmo as não previstas nos manuais, normas e rotina; e de participar das decisões que digam respeito à sua saúde. Além disso, informações sobre a função de outras instituições, como as citadas anteriormente, devem ser apresentadas, de forma que as enfermeiras saibam que podem contar com um maior leque de aliados no alcance do objetivo final de seu trabalho que é a promoção da saúde coletiva.

Diante do exposto e à luz do referencial teórico utilizado, podemos inferir que as enfermeiras, na prestação de assistência, têm como preocupação maior beneficiar o usuário, buscando sua cura ou adesão a tratamento e sua participação nas decisões que digam respeito aos cuidados. Algumas chegaram a lembrar o incentivo à participação nas 
decisões como uma das formas de se favorecer o desenvolvimento da cidadania dos usuánios dos serviços, nāo só para participar ativamente da decisão sobre seu cuidado. mas também sobre outras esferas de sua vida.

Verificamos, através das entrevistas e da observação, que as enfermeiras oferecem informaçōes adaptadas ao usuário que está sendo atendido, buscando esciarecê-lo a respeito de seu problema de saúde, dos cuidados necessários e dos riscos e benefícios que eles comportam. Como muitas as ações são padronizadas a participação do usuánio muitas vezes foi limitada à adesão ou não ao cuidado.

Em relaçāo aos familiares e à coletividade, a não maleficência foi o princípio mais presente. As ações desenvolvidas junto aos usuários que apresentavam problemas ou que tomaram decisōes que poderiam afetar terceiros tiveram como pano de fundo a prevenção de danos e a diminuição da exposição a riscos.

Verificamos que o paternalismo foi explicitado em uma situação: a enfermeira, procurando, na sua visão, beneficiar o usuário, acaba omitindo informação sobre efeitos colaterais da medicação para evitar, o que na sua opinião seria um mal maior: o abandono do tratamento motivado pela associação que o usuánio poderia fazer entre qualquer sinal ou sintoma apresentado e a medicação. Em outra, a enfermeira demonstra postura autoritária ao afirmar que, como conhece a clientela, para alguns, é necessário "dar porrada" para que ele se cuide. 
Apesar de grande parte dos usuários dos serviços em que este estudo foi realizado terem condições de existência adversa, o assistencialismo se fez presente em apenas um dos discursos em que a enfermeira informa que o serviço conta com doações e bazares visando garantir um mínimo de atendimento às carências da vida apresentadas por usuários para que haja alguma possibilidade do cuidado ser realizado. A profissional, entretanto confunde esse assistencialismo com paternalismo.

De modo geral, diante da recusa do usuário em seguir a orientação dada, as enfermeiras procuram saber os motivos dessa recusa, reorientam e em permanecendo a recusa do usuário, aparentemente aceitam essa atitude e registram no prontuário, documentando o fato, quando possivel.

Entretanto, em se tratando de atitude que pode afetar a saúde de terceiros, verificamos que a maioria delas tem um conflito latente entre o respeito à essa expressāo de autonomia e sua "missão" de trabalhadora da área de saúde coletiva, compromissada com a prevenção em todos os niveis. São os casos de mãe portadora de tuberculose que abandona o tratamento e de profissional do sexo que opta pelo uso de diafragma como método contraceptivo.

Devemos afirmar que a enfermeira é o profissional mais institucionalizado do serviço de saúde (tanto em hospitais quanto em unidades básicas como os CSE) pois está presente na unidade durante todo o período de funcionamento, inclusive nos finais de semana. Ela organiza o 


\section{Canclusães}

serviço e a assistência de enfermagem: treina e supervisiona o pessoal auxiliar, provê material, gerencia recursos humanos, faz a "ponte" entre o profissional médico e os usuários nas intercorrências médicas etc., conforme tradicionalmente apreendeu por conta de sua formação escolar e através da experiência prática. Desta forma, são as profissionais que têm maior possibilidade de desenvolver açōes de cunho mais coletivo nas unidades. Enquanto trabalhadoras da área de saúde coletiva acabam sendo responsáveis pelos setores de Vigilância Epidemiológica (em três das quatro unidades estudadas) e vacinação, desenvolvem atividades em grupos operativos (gestante, amamentação, verminose, planejamento familiar), atividades extra-muros (visitas domiciliárias, assistência domiciliar), mantêm relação com outras instituiçōes como escolas, orfanatos, etc., além de atividades de prestação direta de assistência individual. Estas profissionais então, são aquelas que potencialmente assumem a implantação das políticas públicas como próprias, demonstram preocupação com o coletivo, mas desconhecem instrumentos, além daqueles que conta tradicionalmente, e aliados institucionais que poderiam estar ajudando na implementação das ações de saúde coletiva. 
Consideraçäes Finais 


\section{Cansideraçêes finais}

\section{CONSIDERAÇÕES FINAIS}

Durante o transcorrer deste estudo deparamo-nos com situações que suscitaram reflexões acerca da autonomia e da ética na saúde coletiva. Apesar do consentimento esclarecido dizer respeito à participação do usuário em decisões sobre sua própria saúde, na prática assistencial em unidades de saúde como os CSE, decisões individuais pode ter reflexos na saúde da coletividade.

A prática assistencial clínica e a coletiva compartilham objetivos amplos e uma ética básica, mas apresentam diferenças de prioridades e de objeto de trabalho. Para a primeira, o objeto de trabalho são os corpos individuais, que têm uma identidade e se relacionam diretamente com os profissionais de saúde, para a segunda, a população como um todo, em que a identificação das pessoas assistidas nem sempre é possivel.

$\mathrm{Na}$ assistência individual, o princípio do respeito à autonomia das pessoas torna-se relevante a partir da década de 60 devido à importância que passa a ser dada ao indivíduo, à reivindicação da liberdade de pensamento, da hegemonia da razão frente aos dogmas religiosos e ao peso da tradição. "O significado de autonomia passa então a ser compreendido não apenas como tentativa de apreender racionalmente o mundo, mas também de dominá-lo e submetê-lo às finalidades humanas, por via do desempenho de uma razão subjetiva e independente." (SEGRE, SILVA, SCHRAMM, 1998) 


\section{Consideraçêes finais}

Junto ao conceito de justiça, o princípio da autonomia forma os "alicerces morais do 'projeto' moderno que legitimam seu 'programa' civil embasado naquela que Norberto Bobbio indicou como o surgimento da 'cultura dos direitos" (SCHRAMM, 1998)

Estes principios participam da tarefa da construção da cidadania moderna por meio de duas exigências legítimas, mas em conflito: "1) o particularismo das liberdades, preferências e interesses pessoais, pertencentes ao campo do direito de cada individuo e 2) o universalismo das necessidades e interesses comunitários e coletivos, pertencentes ao campo dos direitos de todos os individuos" (SCHRAMM, 1998).

O equacionamento deste conflito depende da aplicação do conceito de justiça, entendida como eqüidade ou imparcialidade, "pois a autonomia individual sem alguma forma de responsabilidade social, garantida por regras de cooperação aceitas por todos não permite superar aquelas condições de guerra de todos contra todos .... ao passo que a responsabilidade social sem autonomia individual pode levar a formas de utopias totalitárias" (SCHRAMM, 1998).

Segundo BEAUCHAMP (1987:69), o paternalismo para a proteção da saúde coletiva não só é "compatível com valores democráticos .... mas também essencial para defender a vida em comum e para promover o senso de comunidade", promover a saúde e a segurança de grupos mais vulneráveis da sociedade.

A vida em sociedade traz muitos benefício para os individuos: segurança, alimentação, infra estrutura, etc. Mas também traz consigo algumas 


\section{Cansideraçâes finaid}

limitaçōes, normas e regras. As pessoas muitas vezes precisam abrir mão de algumas individualidades pelo bem comum.

Na elaboração de políticas públicas deve-se considerar o que DALLARI (1987:108) chamou de dualidades: necessidade e possibilidade; individuos e coletividade; e liberdade e autoridade. "Na escolha dos meios de satisfação das necessidades será necessário, ...., determinar limitações à liberdade individual a fim de aumentar a eficácia dos meios disponiveis. Além disso, para que a dinâmica social se oriente no sentido de um fim determinado, será preciso coordenar a atuação dos individuos e dos grupos sociais, sendo indispensável, portanto, o estabelecimento e a preservação de uma ordem, o que implica a possibilidade de coagir. Esse é um dos mais dificeis problemas das decisões políticas: o encontro do equilíbrio entre a liberdade e a autoridade"(DALLARI, 1987: 109-111).

O Estado realiza, então, as ações de saúde traçadas por uma Política de Saúde desenvolvida diante das dualidades citadas por DALLARI (1987) e que sofre influências de vários setores da sociedade civil através da representação política no Poder Legislativo, da participação popular em diversas instâncias do Poder Executivo (Conselhos federal, Estaduais e Municipais de Saúde, por exemplo) e da própria prestação de serviços.

O desenvolvimento de ações para o controle de doenças pelo Estado Brasileiro surge no final do século passado e tinha como fim único e imediato o de debelar as doenças transmissiveis que ameaçavam a produtividade da população, bem como garantir a circulação e comercialização de alimentos e outros produtos necessários à sobrevivência - febre amarela e variola dentre outras 


\section{Cansideraçōes finais}

(NEMES, 1989). As estratégias utilizadas para o controle dessas doenças foram o policiamento sanitário - fiscalização dos alimentos comercializados e fabricados, da qualidade dos esgotos, da limpeza das ruas, etc.; a desinfeç̧ão - forma privilegiada no combate às doenças transmissiveis; 0 isolamento - em hospitais ou no domicílio no caso de pessoas que tivessem condições para tal; a vacinação; a visita domiciliária e a vigilância da habitação (RIBEIRO, 1993:25-51).

Para o controle de alguns agravos de saúde, o Estado tem elaborado programas especificos. Por exemplo, para o controle de doenças preveniveis por vacinas, instituiu-se o Programa Nacional de Imunização; para o controle da tuberculose e da hanseníase, os Sub programas de Controle da Tuberculose e da Hanseníase. Também, foram órgãos próprios para o combate de doenças especificas como a SUCEN (Superintendência de Controle de Endemias) e a SUCAM (Superintendência de Controle da Malária).

As enfermeiras entrevistadas, enquanto agentes de implantação de política públicas, em seus discursos demonstram sua preocupação quando decisões dos usuários põe em risco a saúde de comunicantes e da comunidade, principalmente no que se refere a doenças transmissíveis. Sentem-se impotentes, sem saber o que fazer, além da notificação do abandono do tratamento, ou da insistência para que o usuário retorne ao tratamento.

Como pudemos ver, as enfermeiras pensam em aparelhos do Estado como aliados no controle desses casos, por exemplo o Juizado de Menores, e, 
acreditamos, em algum órgão repressor, quando uma enfermeira afirma "a gente não é polícia".

A literatura mostra que nos Estados Unidos da América, o país das liberdades individuais, hà uma variedade de meios legais, restritivos, previstos para o controle da tuberculose especificamente: exame médico, tratamento, detenção de emergência, internação em irıstalações do estado, isolamento e quarentena. Alguns estados também impōe penalidades criminais pela violação da ordem da saúde pública ou a transmissāo intencional de doença transmissivel. Muitos têm o poder de ordenar exame médico para diagnóstico de tuberculose ativa em caso de suspeita de doença, ou que tenha se exposto à pessoa doente (Gostin, 1993)

O confinamento, voluntário ou não, também são previstos. Mas o confinamento involuntário recai de forma mais pesada sobre as pessoas com as piores condiçōes de existência, os sem-teto e aqueles que vivem em locais abarrotados e inadequados (tipo cortiço, barracos), porque eles não têm lugar para se auto-confinarem durante o tratamento da tuberculose ativa (Annas, 1993).

No Brasil, a prática mostra que não existem restrições às pessoas que se recusem a tratar de doença transmissivel, ou mesmo a fazer exames para diagnóstico quando existe suspeita da doença. O Código Penal (Brasil, 1940), no capítulo III “Dos crimes contra a saúde pública” determina, em seu Art. 267, que causar epidemia, mediante propagação de germes patogênicos é crime cuja pena prevê a reclusão de 10 a 15 anos; e no Art. 268 que "Infringir determinação do 


\section{Cansideraçäes finais}

poder público, destinada a impedir introdução ou propagação de doença contagiosa" é crme apenado com detenção de 1 mès a 1 ano e multa (acrescida de $1 / 3$ se o agente é funcionário da saúde pública ou exerce a profissão de médico, farmacèutico, dentista ou enfermeiro). Antigamente, antes do surgimento da antibióticoterapia o tuberculoso e o hanseniano eram internado em hospitais e sanatórios especializados e no caso do último, também em colônias, para o seu tratamento, ficando afastado da convivência com seus familiares e sua comunidade. Com o desenvolvimento científico, o tratamento medicamentoso praticamente eliminou a necessidade da utilização dessas estratégias. No caso da tuberculose, a internação ficou restrita aos casos em que as pessoas apresentem condições físicas ou mesmo condiçōes de vida que a indiquem (caquexia, pobreza extrema)

Procurar um aliado legal como o Juizado de Menores, no caso particular da mãe portadora de tuberculose que abandona o tratamento pode gerar um cenáno de conflito que dificulta ainda mais a sua adesão ao tratamento e diminui sua confiança no serviço.

Devemos ressaltar, ainda que a legislação brasileira (Brasil, Lei $n^{\circ} 8069$, de $13 / 07 / 1990)$ não prevè suspensão temporária do pátrio poder para afastar as crianças do contágio. Esse dispositivo legal somente é passivel de aplicação nos casos de proteção à vida da criança: negligência (o seu nāo tratamento caso venha a adoecer, por exemplo)ou maus tratos. 


\section{Cansideraçöes fincais}

Como foi dito antenormente, as enfermeiras desconhecem outros possiveis aliados institucionais que poderiam estar ajudando na sua tarefa. Saber o que esses órgãos e instituiçōes fazem, como podem ser acionados poderiam atenuar o cenário ce conflito entre o profissional que quer tratar a usuária e prevenir novos casos e os interesses dessa usuária no que diz respeito a sua sobrevivência, seus vinculos familiares e afetivos.

Considerando que a comunidade deseja se proteger de doenças e as peculiaridades do trabalho em saúde coletiva, é necessário que o setor saúde, em conjunto com a população busque formas para o seu controle na comunidade. No caso de doenças iransmissiveis, verificamos através da bibliografia que nos Estados Unidos, as estratégias possiveis de serem utilizadas vão desde o encarceramento e o isolamento até o oferecimento de suporte social. No Brasil, após muitos anos de luta para a desestigmatização de doenças como a tuberculose e a hanseniase, acreditamos que as duas primeiras opções seriam um retrocesso. Assim, os problemas devem ser apresentados à população nas instâncias de participação popular, como os conselhos municipais de saúde, possibilitando à comunidade, encontrar soluções para os problemas. O suporte social, a medicação supervisionada ou a visita domiciliária diária para a medicação são algumas das aiternativas que possibilitariam o tratamento de pessoas em condições sociais cesfavoráveis como o caso da senhora que abandonou o tratamento de tuberculose Agindo desta forma, a comunidade estaria aplicando a máxima "tratar desigualmente os desiguais", contido no principio da justiça. 
Referências Bibliográficas 


\section{REFERÊNCIAS BIBLIOGRÁFICAS}

Almeida MCP. $O$ trabalho de enfermagem e sua articulação com o processo de trabalho em saúde coletiva: rede básica de saúde em Ribeirão Preto. Ribeirão Preto; 1991. [Tese de Livre-Docência. Escola de enfermagem de Ribeirão Preto - USP].

Almeida MCP, Rocha JSY. O saber de enfermagem e sua dimensão prática. São Paulo: Cortez; 1986.

Almeida MCP, Rocha, SMM. (org.) O trabalho de enfermagem. São Paulo: Cortez; 1997.

Alves DB. Mercado de trabalho e condições de trabalho da enfermagem. Salvador: Gráfica Central; 1987.

Annas GJ Control of tuberculosis - the law and the public's health. N. Engl. J. Med. : 1993. 328 (8):585-8.

Appelbaum PS, Lidz CM, Meisel A. Informed consent: legal theory and clinical practice. Oxford: Oxford University Press; 1987.

Arnold RM, Lidz CW. Clinical aspects of informed consent in health care. In: Reich WT (ed.) Enciclopedia of Bioethics. Revised edition. New York: Macmillan, 1995.

Barros SMPF, Silva NF. Brasil - sistemas locais de saúde - enfermagem. Rev. Bras. Enferm. Brasilia, 1990; 43(1/4):126-30. 
Beauchamp D. Life-style, public health and paternalism. In: Doxiadis S. (ed.) Ethical dilemmas in health promotion. Great Britais: John Wile \& Sons; 1987. p.69-81.

Beauchamp TL. Meaning and elements of informed consent. In: Reich WT (ed.) Enciclopedia of Bioethics. Revised edition. New York: Macmillan, 1995.

Beauchamp TL, Childress JF. Principles of biomedical Ethics. $3^{\text {rd }}$ ed. New York: Oxford University Press, $1989.470 \mathrm{p}$.

Beauchamp TL, Childress JF. Principles of biomedical Ethics. $4^{\text {th }}$ ed. New York: Oxford University Press, 1994.546 p.

Beauchamp TL, Faden R. Informed consentMeaning and elements of informed consent. In: Reich WT (ed.) Enciclopedia of Bioethics. Revised edition. New York: Macmillan, 1995.

Brasil. Código de defesa do consumidor: lei n $^{\circ} 8078$ de 11 de setembro de 160/93 de 12 de maio de 1993) São Paulo: COREN-SP; 1996.

Brasil. lei $n^{\circ} 8080$, de 19 de setembro de 1990. Dispōe sobre as condiçōes da promoção, proteção e recuperação da saúde, a organização e o funcionamento dos serviços correspondentes e dá outras providências. Diário Oficial da República Federativa do Brasil, Brasilia 20/9/90. Seção I p. 18055-59.1990.

Brasil. Estatuto da Criança e do Adolescente, lei $n^{\circ} 8069$, de 13 de julho de 1990. São Paulo: Cortez; 1991. 
Brasil. Conselho Federal de Medicina. Resolução CFM n 1.359/92. Diário Oficial da República Federativa do Brasil, Brasilia 19/11/92. Seção I p.16054.

Brasil. Código penal, Decreto lei $\mathrm{n}^{\circ} 2848$ de 7 de dezembro de 1940. / Organização dos textos, notas remissivas e indices por Juarez de Oliveira. 30a ed. São Paulo: Saraiva, 1992.

Brasil. Ministério da Saúde. Centro Nacional de Epidemiologia. Coordenação de Pneumologia Sanitária. Manual de normas para o controle da tuberculose. $4^{a}$ ed. Brasilia, Ministério da Saúde; 1995.

Brasil. Conselho Federal de Enfermagem. Código de ética dos profissionais de enfermagem. Resolução COFEN 160 de 12 de maio de 1993. In: Conselho Regional de Enfermagem - SP. Principais legislaçōes para o exercício da enfermagem. São Paulo; COREN-SP, 1996.

Brasil. Ministério da Saúde. Secretaria de Assistência à Saúde. Conselho Nacional de Saúde. Programa Nacional de Doenças Sexualmente Transmissiveis/AIDS. Resolução 196 de 10 de outubro de 1996 Diretrizes e normas reguladoras de pesquisas envolvendo seres humanos. Brasilia. Ministério da Saúde. 1997. 20 p.

Burman WJ. Short-term incarceration for the management of nomcomoliance with tuberculosis treatmeant. Chest, $1997 ; 112(1)$ : 57-62.

Castellanos, et alii . Os desafios da enfermagem para os anos 90. In: Anais do 410 Congresso Brasileiro de enfermagem , 1989, Set.; Florianópolis, Brasil: Associação Brasileira de Enfermagem. p.147-169. 
Coelho LCD. Percepção das enfermeira a cerca da responsabilidade ético legal no exercício profissional. Florianópolis; 1993 [Dissertação de Mestrado. Centro de Ciências da Saúde, Universidade Federal de Santa Catarina].

Cohen C, Marcolino JAM. Relação médico paciente - a) autonomia e patemalismo. In: Segre M ; Cohen C. Bioética. São Paulo: EDUSP;1995. p.5162.

Costa SIF, Garrafa V, Oselka G. Apresentando a bioética. In (Coord.) Iniciação à bioética. Brasilia, Conselho Federal de Medicina; 1998. p. 15-18.

Culver CM. Gert B. Philosophy in medicine. New York: Oxford Press; 1982. apud Fortes PAC. Ética e saúde: questões éticas, deontológicas e legais. Tomada de decisōes, autonomia e direitos do paciente. Estudo de casos. São Paulo: EPU; 1998. p.51.

Dallari DA. Elementos de teoria geral do Estado. 13 ed. Sāo Paulo: Saraiva, 1987. 259p.

Durant G. A bioética: natureza, principios, objetivos. São Paulo: Paulus, 1995. p. 34-36.

Faden RR, Beauchamp TJ King NMP. A History and theory of informed consent. New York: Oxford University Press; 1986.

Ferreira AMTGB. Informaçōes prestadas a clientes sobre benefícios, riscos e conseqüências da assistência de enfermagem - um estudo exploratório. São Paulo, 1998. [Dissertação de Mestrado. Faculdade de Saúde Pública USPI. 
Fortes PAC. Reflexões sobre a bioética e o consentimento esclarecido. Bioética. 1994; 2:129-135.

Fortes PAC. O consentimento informado na atividade médica e a resposta dos tribunais. Justiça e Democracia. 1996; 1(2): 185-197. (a)

Fortes PAC. Ética, cidadania e busca de qualidade na administração dos serviços de saúde. Saúde em debate. dez. 95 - mar. 1996; (49/50): 48-52.

Fortes PAC e col. Informação em saúde: expressão da autonomia dos pacientes. São Paulo: 1997, Faculdade de Saúde Pública - USP. Relatório final de pesquisa apresentada à Fundação de Amparo à Pesquisa do Estado de São Paulo. [mimeografado].

Fortes PAC. Ética e saúde: questões éticas, deontológicas e legais. Tomada de decisōes, autonomia e direitos do paciente. Estudo de casos. São Paulo: EPU; 1998. 119p.

Garrafa V. Desafios éticos na política de recursos humanos frente às necessidades de saúde. Cadernos RH Saúde. 1994; 1(3): 9-18.

Germano RM. A ética e o ensino da ética na enfermagem do Brasil. Sāo Paulo: Cortez; 1993.

Gonçalves RBM. Tecnologia e organização social das práticas de saúde: características tecnológicas de processo de trabalho na rede estadual de centros de saúde de São Paulo. São Paulo: HUCITEC/ABRASCO;1994. 
Gostin LO. Controlling the resurgent tuberculosis epidemic. A 50 state survey of TB statutes and proposals for reform. JAMA; 1993. 269(2):255-61.

Haguette TMF. Metodologias qualitativas na sociologia. 4 ed. Petrópolis: Vozes; 1995.

Holm S. Autonomy. In Encyclopaedia of applied Ethics. USA Academic press; 1998. v. I. p: $267-74$

Ludcke M, Andre, MEDA. Pesquisa em educaçāo: abordagens qualitativas. São Paulo: EPU; 1986.

Merhy EE, Cecilio LC, Nogueira Filho RC. Por um modelo tecno-assistencial da política de saúde em defesa da vida: contribuição para as conferências de saúde. Saúde em debate, 33: 83-89. 1991.

Mill JS. Introductory In: On Liberty. In: Hutchins RM. (ed) Great books of the western world. Chicago; Encyclopædia Britannica; 1952. v. 43. c.1. p. 267-74.

Minayo MC de S. O conceito de representações sociais dentro da sociologia clássica. In: Guareschi, P. \& Jovchelovitch,S. (org.) Textos em representações sociais. 2 ed. Petrópolis: Vozes;1995. p. 89-111.

Minayo MCS. 0 desafio do conhecimento: pesquisa qualitativa em saúde. 2 ed. HUCITEC-ABRASCO, São Paulo - Rio de Janeiro; 1993.

Moreno JD, Caplan AL, Wolpe PR. Informed consent In: Encyclopaedia of applied Ethics. USA: Academic Press; 1998. v.2. p. 687-97. 
Muñoz DR, Fortes PAC. O princípio da autonomia e o consentimento livre e esclarecido. In: Costa, SIF, Garrafa V, Oselka G. (Coord.) Iniciação à bioética. Brasilia, Conselho Federal de Medicina; 1998. p. 53-70.

Naffah Neto A. O estigma da loucura e a perda da autonomia. Bioética. 1998;(6): 81-7.

Nemes, MIB. Ação programática em saúde: recuperação histórica de uma política de Programação. In Schariber LB (org) Programação em saúde hoje. São Paulo: HUCITEC; 1990. p.65-116.

Oliveira FVS. Associação Brasileira de enfermagem; mudanças e continuidades - a propósito do movimento participação (1979/1989). Natal, 1990 [Dissertação de mestrado - Centro de Ciências Humanas, Letras e Artes, Universidade Federal do Rio Grande do Norte] apud Germano RM. A ética e o ensino da ética na enfermagem do Brasil. São Paulo: Cortez; 1993. p. 52.

Orem DE. Nursing: concepts of practice. USA, St. Louis: Mosby Year Book, 1991. 385p.

Paim JS, Teixeira MGLC. Reorganizaçāo do Sistema de Vigilância Epidemiológica na perspectiva do Sistema Único de Saúde (SUS). In: Anais do Seminário Nacional de vigilância epidemiológica. Brasília. Fundação Nacional de Saúde, CENEPI, 1993.

Passos ES. A ética na enfermagem. R. Bras. Enferm. Brasília. 1995; 48(1):8992. p. 86 . 
Passos ES. Tendências da ética profissional na Modernidade. R. Bras Enfer. Brasilia;1993. 46(1): 56-62.

Pelicioni MCF. Serviços de saúde: utilização e opinião de usuários. São Paulo; 1989. [Monografia de mestrado. Faculdade de Saúde Pública da Universidade de Sāo Paulo]

Pellegrino ED. La relación entre la autonomía y la integridad en la ética médica. Bol. Of. Sanit. Panam. 1990. 108(5-6):379-390.

Pessini L, Bachifontaine CP. Bioética: do principialismo à busca de uma perspectiva. In: Costa, S.I.F.; Garrafa, V. \& Oselka, G. (Coord.) Iniciaçāo à bioética. Brasília: Conselho Federal de Medicina, 1998. p. 81-98.

Pessini L, Barchifontaine C de P. (org.) Fundamentos de bioética. São Paulo: Paulus, 1996.

Reich WT. (ed.) Encyclopedia of Bioethics. Revised edition. New York; Macmillan, 1995.

Ribeiro MAR. História sem fim ... inventário da saúde pública. São Paulo: Editora da Universidade Estadual Paulista, 1993.

Sandoval SAM. Algumas reflexões sobre cidadania e formação de consciência politica no Brasil. In: Spink MJP. A cidadania em construção. São Paulo: Cortez, $1994 ;$ p. $62-64$.

São Paulo (Estado) Decreto Lei n 3876 de 11 de julho de 1925, aprovado pela lei $n^{\circ} 2121$ de 30 de dezembro de 1925 (mimeografado). 
São Paulo (Estado) Decreto Lei nº 17.357 de 2 de julho de 1947, Dispõe sobre a criação do Serviço Especial de Saúde e dá outras providências

São Paulo (Estado) Constituição do Estado de São Paulo. Seção da Saúde (Arts. 219 a 231) In: Código de saúde: Lei complementar $n^{\circ} 791$ de 9/3/95. p. 67-74.

São Paulo (Estado) Secretaria de Estado da Saúde. Direitos do paciente. s/d. $16 \mathrm{p}$.

Saul AM. Sobre os determinantes de perfil profissional: o caso da enfermagem. In: Seminário da Região Sudeste. Perfil e competência do enfermeiro e o curriculo mínimo para a graduação em enfermagem: anais. São Paulo; 1988. p. 30.

Schraiber LB. Programação hoje In Schraiber LB. (org) A programação em saúde hoje. São Paulo: HUCITEC;1990. P.11-35.

Schramm FR. A autonomia difícil. Bioética; 1998(6): 27-37.

Segre M. Silva FL, Schramm FR. O contexto histórico, semântico e filosófico do principio da autonomia. Bioética, 1998; 6:15-23.

SERVIÇO Especial de Saúde de Araraquara. S/d [ mimeo].

Shuqair NSMSA.Q. A política de vigilância sanitária de medicamentos: um estudo de caso na região da Lapa - Municipio de São Paulo. São Pulo, 1996. [Dissertação de mestrado. Faculdade de Saúde Pública - USP].p12-13. 
Sillveira C. O significado da prática profissional e do ensino em unidade básica de saúde: um estudo da cultura organizacional no Centro de Saúde Escola da Barra Funda. São Paulo, 1999. [Tese de Doutorado. Faculdade de Saúde Pública - USP]. p.69.

Silva Jr. AG, Modelos tecnoassistenciais em saúde: o debate no campo da Saúde Coletiva. Rio de Janeiro; 1996. [Tese de doutorado Escola Nacional de Saúde Pública]

Silva MGR. Prática médica: dominação e submissão - uma analise institucional. Rio de Janeiro, Zahar, 1976. Apud Siqueira, M.M. Organização da prática médica: que fale o paciente. RAP. Rio de Janeiro; 1985. 19(1): 4-25.

Siqueira JE. O principio da justiça. In: Costa SIF, Garrafa V, e Oselka G. (Coord.) Iniciaçāo à bioética. Brasilia, Conselho Federal de Medicina: 1998. p. $71-80$.

Souza ZS, Moraes MIDM. Ética médica e o respeito às crenças religiosas. Bioética. 1998;(6): 89-93.

Villa TCS, Mishima SM, Rocha SMM. A enfermagem nos seviços de saúde pública do Estado de São Paulo. In: Almeida MCP, Rocha SMM. (org) O trabalho de enfermagem. São Paulo: Cortez; 1997. 
Anexas 


\section{ANEXO 1}

Roteiro para caracterização do serviço

CENTRO DE SAÚDE ESCOLA

Criado em (ano)

Instituiçōes mantenedoras

Vinculado ao Departamento/Disciplina de

Chefia:

Horário de funcionamento:

Programas e atividades desenvolvidos

Intramuros

extra-muros

Qual o modelo assistencial utilizado pelo serviço? 
O CSE participa na formação de alunos dos cursos de:

Graduação em

Especialização em

Residència em

Pós-graduação em

Outros cursos:

Técnico de enfermagem

Auxiliar de enfermagem

THD

$A C D$

Enfermeiras

\begin{tabular}{|l|l|l|l|}
\hline NÚMERO & LOTAÇÄO & CARGA HORÁRIA & HORÁRIO \\
\hline & & & \\
\hline & & & \\
\hline & & & \\
\hline
\end{tabular}




\section{ANEXO 2}

Roteiro para entrevista com a enfermeira

1. Identificação

Entrevista $n^{\circ}$

Data:_L___ Local

Horário de início término

Nome

Idade Sexo

Cargo: Função

Trabalha há quanto tempo no CSE

2. Formação

Graduação

Escola

Ano

Outros cursos 
3. Trabalho

3.1. Fale um pouco sobre sua trajetóna profissional e como você veio trabalhar em Centro de Saúde Escola.

3.2. Tem outra atividade profissional? Qual? Onde? O que você faz lá?

3.2. Quais as atividades que você desenvolve, normalmente na unidade?

Assistenciais

Ensino

Pesquisa

Administrativas

Com a comunidade 
4. Ponto de partida para discussão

Tente se lembrar das atividades desenvolvidas no dia de ontem.

a) Em quais tomou decisões que diziam respeito ao cuidado ao cliente? (prestação direta, ensino, supervisão

b) De que forma essas decisões foram tomadas? O que você levou em consideração?

c) O usuário pode participar em decisões que digam respeito ao seu cuidado? Em que condiçōes ele pode e não pode?

d) Se o usuário se recusa ou declara opção por tratamento diferente daquele prescrito por você, o que você faria? (por exemplo uso de água oxigenada e mercúrio cromo no ferimento em detrimento ao soro fisiológico)

e) Já ouviu falar em "consentimento esclarecido" ou "informado"? Para você, o que é isso? 


\section{ANEXO 3 \\ Roteiro para observação das atividades da enfermeira}

Descrição da atividade observada: o que se faz, como se faz, onde se faz, quando se faz, se a atividade é programada ou não

Em caso de prestação de assistência, registrar o que se pergunta e o que se fala para o usuário, qual as condutas tomadas, o que é registrado e qual a atitude das pessoas

Em caso de atividade de ensino, treinamento, supervisão, reuniões, etc registrar qual a atividade, com quem foi realizada, onde, o que foi falado e qual a atitude das pessoas envolvidas.

Será prestada maior atenção aos seguintes aspectos

1. A aplicação prática dos princípios éticos da autonomia, beneficência, não maleficêrıcia e justiça na rotina de trabalho (assistência, administração e ensino)

2. Participação da informação, deliberação e decisão

3. Condições de trabalho que dificultam a prática da obtenção do consentimento esclarecido

4. Condições de trabalho que favorecem a prática da obtenção do consentimento esclarecido 


\section{ANEXO 4}

Os sujeitos da pesquisa

E1

Sexo feminino, 38 anos, trabalha no serviço há 16 anos e 8 meses, formou-se há 6 anos, em faculdade privada, fez Habilitação em Enfermagem de Saúde Pública na Faculdade de Saúde Pública da USP. Atualmente está aposentada e prestando serviços na unidade 4 horas por dia, desenvolvendo principalmente atividades de supervisão.

\section{E2}

Sexo feminino, 37 anos, trabalha há 13 anos no serviço. Formou-se há 16 anos em Escola pública, onde cursou Habilitação em Enfermagem de Saúde Pública. Fez os cursos de Especialização em Saúde Pública e de Especialização em Enfermagem de Saúde Pública na FSPIUSP. Há dois anos assumiu a chefia de enfermagem do serviço. Tem por atividades assistenciais a realização de grupo de verminose e de recém nascidos e eventualmente pré e pós consultas, vacinação e medicação. Realiza supervisão de postos de vacinação credenciados pela unidade.

Desenvolve suas atividades no serviço em regime de 30 horas semanais e no período da tarde trabalha em atividade não relacionada à área da saúde. 
E3

Sexo feminino, 39 anos, trabalha no serviço há 2 anos e 10 meses. É enfermeira do Ministério da Saúde, prestando serviço na unidade. Formou-se e fez fez Habilitação em Enfermagem de Saúde Pública e Licenciatura em Enfermagem em universidade pública. Especializou-se em Saúde Pública e em Doenças Sexualmente Transmissiveis.

Trabalhou durante dois anos em unidade básica da Prefeitura de São Paulo, localizada na Zona Leste, e durante 10 anos no Posto de Assistência Médica Várzea do Carmo do Instituto Nacional de Assistência Médica e Previdência Social (INAMPS), ambulatório de especialidades, onde, durante os três últimos anos, fez parte da equipe multiprofissional do "Serviço de Atendimento ao Usuário", recebendo e procurando dar soluções a reclamações, denúncias e reivindicações por parte dos usuários da unidade.

Atualmente desenvolve as seguintes atividades: pré e pós consulta, consulta de enfermagem (atendimento de enfermagem realizado pela enfermeira), prevenção de incapacidades, coordena as atividades desenvolvidas no setor e recebe estagiários e treinandos de outros serviços.

\section{E4}

Sexo feminino, 39 anos, trabalha na unidade há três anos. Formou-se em escola privada onde fez Habilitação em Enfermagem Obstétrica durante a graduação há 18 anos. Fez Especialização em Administração Hospitalar em universidade privada. 
Trabalhou em hospitais privados e em hospital de ensino, com ênfase na área de saúde da mulher. Atualmente, além de trabalhar na unidade, desenvolve atividade em consultório particular, ministrando cursos de gestante e de planejamento familiar.

Desenvolve ações cuidativas através de grupos de gestante, planejamento familiar e atendimento de enfermagem no Programa de Assistência à Vítima de Abuso Sexual (PAVAS).

\section{E5}

Sexo feminino, 28 anos, trabalha na unidade há très anos e meio. Formou-se en escola privada há 8 anos, fez Especialização em Enfermagem Obstétrica em Faculdade e Especialização em Administraçāo em escolas privadas.

Foi enfermeira em um CSI localizado na região central de São Paulo por três anos e meio, tendo assumido a chefia de enfermagem nos últimos anos, onde teve pouco contato direto com a clientela.

Atualmente, é coordenadora do programa de assistência domiciliária: faz as visitas de triagem, cronogramas de saída, e avaliação dos casos junto com a equipe de saúde. Desenvolve atividades de assistência junto ao programa de saúde da mulher, na coleta de Papanicolau, no atendimento em grupo e individual de gestantes. Desenvolve trabalho educativo com uma escola da região, nos temas DST e planejamento familiar e está iniciando atividade de controle de hipertensão arterial e de colesterol junto a empresas da região, em conjunto com a equipe de saúde. 
E6

Sexo Feminino, 34 anos, trabalha na unidade há 3 anos. Formou-se em Escola pública há 7 anos. Fez Licenciatura em Enfermagem e Aprimoramento em Saúde Coletiva.

Após se formar, trabalhou como enfermeira em Centro Integrado - CIEP em uma cidade do interior de outro estado, desenvolvendo atividades com professores e alunos. Trabalha como supervisora do plantāo notumo no Hospital Darcy Vargas desde 1994.

Tem por atividades assistenciais: denominadas por ela como "tapa buraco": atendimento de enfermagem eventual a hipertensos, mulheres em situaçāo de violência, gestante, etc... e atividades planejadas junto ao grupo de planejamento familiar, consulta para mensuração de colo uterino e orientação para a colocação de diafragma. É responsável pela Vigilância Epidemiológica de doenças de notificação compulsória e outras de interesse para o serviço (como o càncer de colo uterino e doenças exantemáticas) e de gestantes.

Atualmente está desenvolvendo pesquisa sobre mortalidade materna junto com alunos de Medicina, em substituição à colega que está em licença matemidade, e no planejamento de atividades de grupo de planejamento familiar na comunidade junto a mulheres marginalizadas.

E7

Sexo feminino, 39 anos, trabalha na unidade há 16 anos. Atualmente é chefe da seção tècnica de enfermagem. Formou-se há 17 anos, fez Habilitação em 
Enfermagem de Saúde Pública, especializou-se em Saúde Pública e obteve o grau de mestre em universidade pública. O tema de sua monografia foi: Programa de Imunização, um Desafio Continuado. Trabalha na unidade desde que se formou.

Desenvolve atividades administrativas, assistenciais e de ensino entre as quais destacamos, coordenação das atividades de enfermagem, credenciamento e supervisão de postos de vacinação, avaliação de dados de vacinação e vigilância epidemiológica no sistema de informação do Serviço. Elabora relatónios mensais para cada UBS do município sobre faltosos na vacinação. e consolida dados sobre doenças de notificação.

Faz vacinação, cobertura de foco, orientações a pacientes com DST e AIDS, e busca ativa de doenças de notificação compulsória. Periodicamente trabalha nos fins de semana e feriados, em regime de plantão desenvolvendo atividades programadas (vacinação, Vigilância epidemiológica, convocação de faltosos, etc)

\section{E8}

Sexo feminino, 44 anos, trabalha no serviço há 3 anos e meio. Formou-se em escola pública há 21 anos. Fez Habilitação em Enfermagem Médico-cirúrgica durante a graduação e especializou-se em Saúde Pública em universidade privada.

Trabalhou por sete anos no Hospital das Clinicas da Faculdade de Medicina/USP. Posteriormente desenvolveu atividades em hospital geral, unidade mista e centro de saúde, no interior do Estado de São Paulo 
participando na organização do sistema de saúde local e na introdução dos agentes de saúde. Desenvolveu atividades de vigilância epidemiológica e imunização em Escritónio Regional de Saúde (ERSA) por três anos.

Quando veio para o serviço, ficou por três anos na saúde infantil. Atualmente está na vigilância epidemiológica. Desenvolve atividades administrativas, assistenciais e de ensino dentre as quais destacamos a orientação na pós consulta a pacientes novos, soropositivos para AIDS, o controle de comunicantes, as visitas domiciliánias. Dá orientações via telefone, principalmente de dengue, já que surgiram casos na região coordena as atividades de busca ativa de casos de dengue, de convocação de casos suspeitos; faz controle de preservativos, de exames específicos, elabora de planilha de pacientes soropositivos, relatónios mensais de atividades; e as atividades de rotina de notificação (elaboração do SVE3, notificação semanal de doenças).

E9

Sexo feminino, 36 anos trabalha no serviço há 11 anos. Formou-se em escola pública há 13 anos. Fez a Habilitação Em Enfermagem de Saúde Pública a Especialização em Saúde Pública em universidade pública.

Trabalhou em um Municipio da Grande São Paulo, por seis meses, e em 1987, veio para o serviço, desenvolver suas atividades em dois postos de saúde que integravam o serviço na época. Após um ano, com a municipalização dos serviços, passou a trabalhar na unidade. 
Dentre as atividades desenvolvidas, destacamos: pós consulta, visita de inscrição e de faltosos dos programas de hanseniase e tuberculose; eventualmente consulta de enfermagem nesses programas. Treinamento de enfermeiros da região no projeto "sinal de Alerta" (para detecção precoce da hanseniase). Nos plantōes: vacinação, vigilância epidemiológica, "o que aparecer".

Realiza atividade com empresas para informar sobre a hanseniase, divulgação de informaçōes no rádio: sobre a doença e sobre o programa "Sinal de Alerta" sobre diagnóstico precoce da hanseniase.

E10

Sexo feminino, 39 anos, trabalha no serviço há 5 anos e 10 meses. Formou-se em escola privada há 18 anos. Fez Licenciatura em Enfermagem e Especialização em Pediatria Comunitária e Especialização em Saúde Coletiva em universidades públicas. Fez também curso de Homeopatia em entidade privada,

Trabalhou em hospital geral por 6 meses, em unidade básica da Secretaria de Estado da Saúde de São Paulo e posteriormente em hospital especializado em tuberculose. Em 1985 passou a trabalhar em unidade básica do Municipio, onde ficou 5 anos. Desenvolveu também atividades na Escola Técnica do Estado, atual Instituto Paula Souza, no curso de Técnico de Enfermagem.

Dentre as atividades que desenvolve, destacamos as seguintes: responsabilidade pelas atividades de enfermagem nos Programas de Saúde da 
Mulher e da Criança, sendo que tem por atividades administrativas: elaboração de relatórios, atendimento à gestante, pós consulta, atendimento de enfermagem em grupo, atendimento de enfermagem no puerpério, esporadicamente visita hospitalar às puérperas, coleta de material para exame de Papanicolau, avaliação de mamas, orientação para o aleitamento materno é monitora e treinadora em aconselhamento de aleitamento materno na região. Ministra palestras em escolas, AAA, na zona rural e para profissionais de saúde. Nos plantōes: de final de semarı realiza açōes de vigilância epidemiológica, vacinação e administração de medicamentos para Hanseniase.

\section{E11}

Sexo feminino, 38 anos, trabalha na unidade há 6 anos e meio. Atualmente é Chefe de Enfermagem da Saúde do Adulto. Formou-se há 15 anos em escola pública, onde fez a Habilitação em Enfermagem. Especializou-se e Administração Hospitalar por faculdade privada e em Enfermagem Obstétrica em escola pública.

Trabalhou em outro estado durante três anos, dando aula na Cruz Vermelha e trabalhando em hospital. Em São Paulo, trabalhou em hospitais e em Centro de Saúde II na Zona Leste de São Paulo. Atualmente, além da atividade na unidade, trabalha em maternidade no plantão noturno.

Desenvolve suas atividades em regime de trabalho de 32 horas. Dentre suas atividades destacamos a chefia de enfermagem da saúde do adulto, responsabilidade por atividades de apoio, grupo, consultas de enfermagem, 
controle das mulheres que estão usando diafragma, atendimento eventual de gestantes, encaminhamento de casos ao Oncocentro, tratamento de leucorréias (segundo padronização do serviço) e outros problemas que o pessoal" não consegue dar conta "

Em termos de pesquisa, desenvolveu atividade de campo de pesquisa desenvolvida por pesquisador de outra Universidade sobre método contraceptivo, ficando responsável pela captação, atendimento e controle de pacientes.

E12

Sexo Feminino, 36 anos, trabalha na unidade há 11 anos. Formou-se há 14 anos em escola pública, fez Aprimoramento em Saúde Coletiva em faculdade pública. Foi enfermeira em um "mini centro" de saúde localizado em uma favela de Osasco.

Veio trabalhar na unidade em 1987. Quando passou a desenvolver atividades na Saúde do Adulto. Após três anos assumiu a estatística e epidemiologia Trabalhando em regime de 32 horas, atualmente acumula a Chefia do serviço de Enfermagem, o que restringiu o desenvolvimento de suas atividades assistenciais à leitura de PPD, visitas complicadas (pela dificuldade de aceitação por parte da população de maior poder aquisitivo em "ser invadida pelas meninas (pessoal de nível médio)", surto de doença transmissivel em instituição, orfanato). 
Participa de treinamentos, de seminários para aprimorandos em Medicina Social, internos (esporadicamente) e residentes de medicina, sobre vigilância epidemiológica ou avaliação de serviços

Tem por atividades administrativas a responsabilidade por 30 a $40 \%$ do pessoal do serviço, a coordenação dos estágios, a geração do faturamento mensal. É responsável pela geração do boletim mensal de produção, da planilha de gerenciamento do serviço; a elaboração de avaliações internas e de tabelas de dados para pesquisas. Esporadicamente elabora boletins informativos, para divulgação de inovações na área da saúde.

Quanto à pesquisa, desenvolve atividades de apoio, coordenação de atividade de campo, auxilio na elaboração de instrumento de coleta de dados. Tem artigos publicados sobre avaliação de serviço e contribui com o jornal do bairro.

\section{E13}

Sexo feminino, 36 anos, trabalha na unidade há 1 ano. Formou-se em escola privada há 16 anos. Fez licenciatura em Enfermagem durante o curso e Habilitação em Enfermagem Obstétrica na mesma Faculdade. Fez Especialização em Saúde Pública em universidade privada em 1988 e Especialização em Enfermagem Obstétrica em escola pública.

Trabalhou em hospitais privados em São Paulo, na área de obstetricia e em Escola de Auxiliar de Enfermagem do INANPS.

Sendo comissionada na unidade, trabalha em regime de 30 horas semanais. 
Desenvolve atividades assistenciais no grupo de aleitamento materno e na falta de funcionário, no atendimento de enfermagem à criança, vacinação e grupo de crianças

Toma parte em reuniões sobre pesquisa sobre aleitamento materno a ser realizado na unidade. 


\section{ANEXO 5}

Trechos de relatónios de observação de atividades

\section{Observação 1 - Pós Consulta}

Chegando à unidade, encontrei a enfermeira. dingindo-se à pós consulta da tisiologia.

ENF. Q Que bom que vocẽ chegou, vou fazer uma pós consulta de caso novo de TB. Como sempre estou tapando falta de funcionário.

Entramos na sala, apresento-me ao paciente, digo que estou fazendo uma pesquisa sobre o relacionamento enfermeiro-usuário. Informo-o que será garantido anonimato e solicito autorização para observar a atividade. Ele diz que não há problema algum.

F. Sr Usuário, como vai?

Usuário- Eu queria um socorro, sobre minha alta e a licença do trabalho.

ENF. Espera um poquinho, deixa eu dar uma lidinha no seu prontuário. Isto aqui é a contra referência para o $\mathrm{HC}$, o Sr. Veio encaminhado de lá e este papel é para dizer o que foi feito aqui

Medico interrompe bruscamente e se dirige para a enfermeira:

Pedido de eletro!

$\bar{E} N F$. pede licença ao paciente, levanta-se e entrega o impresso ao médico.

ENF. - Desculpa viu Sr. X.

- O que o Dr.. falou com o senhor sobre sua doença?

Usuário: Que eu tenho TB, já vim do serviço sabendo, sou auxiliar de enfermagem

ENF.- Tem alguma coisa que você quer saber.

Médico interrompe novamante, entrega prontuário para pós consulta, dizendo que os pacientes estão aguardando no saguão.

ENF., voltando-se para o paciente: Eu sei que o Sr. sabe, mas vou partir do princípio de que o Sr. é um paciente como outro qualquer da unidade. (pega um prisma de cartolina em que estão grudados comprimidos e cápsulas de diversas cores e número, com os respectivos nomes ao lado). Estes medicamentos (mostra duas cápsulas vermelhas) o Sr deve tomar de manhã em jejum.

Usuário: Eu trabalho à noite.

ENF. Vamos ver sua dinâmica.... O Sr janta de manhã ou de madrugada? 
Usuánio: Eu janto normalmente às 5 horas da tarde

ENF. Tem lanche no hospital?

Usuánio: Mais ou menos às 10 horas (22h), depois eu não como mais nada. Só vou tomar café antes de deitar. Posso tomar os comprimidos no HC, antes de ir embora para casa.

ENF. Até ir para casa, dá mais ou menos meia hora?

Usuário: Dá mais, eu moro em Sapopemba.

ENF. Depois de tomar o café da manhã, quantos comprimidos é para tomar? (mostra 4 comprimidos de Pirazinamida)

Usuário: Quatro.

ENF. Vamos te dar um pouco de comprimidos a mais porque pode ser que seu retorno seja marcado para mais de um mês.

Usuário: Eu prefiro passar em consulta depois do meu plantão, assim não preciso voltar outro dia só para passar em consulta.

ENF. Se tiver festa, viagem não é para parar de tomar o medicamento, é para levar junto.

O médico pediu um exame de escarro para controle.

Como o sr. colheu no HC?

Usuário: Na saída do plantão. Três amostras.

ENF. Foi para diagnóstico, agora vai precisar só de um.

Pode trazer qualquer dia. Pode ser saliva?

Usuário: Não

ENF. Pode ser da garganta?

Usuário: Não

ENF. É, tem que ser de dentro do pulmão..Em que setor o Sr. trabalha?

Usuário: No PS

ENF. Então podemos trocar figurinhas, você fala sobre o seu serviço e eu falo sobre o meu.

.....Bom, primeira consulta tem muito papel para preencher (preenche pedido de escarro). O Sr. deve trazer o material aqui mesmo neste prédio........ senhor já fez o teste de HIV.... 
Usuário: Tenho feito, vou trazer na próxima consulta médica.

Outro médico interrompe. Quer resolver um problema sobre troca de consultóno. Cada dia está atendendo em uma sala diferente ou prédio diferente. ENF. pede para que ele aguarde um pouquinho que ela está terminando o atendimento. Médico fica em pé no canto da sala aguardando, já que veio hoje somente para tentar resolver este problema.

ENF.... viu $\mathrm{Sr} X$, o Sr. precisa fazer exames de controle: escarro e raio $\mathrm{X}$. Pode interromper o tratamento depois de dois meses?

Usuário: Não

Quanto tempo dura o tratamento?

Usuánio: Seis meses.

ENF. preenche ficha do cardex pergunta dados de identificação, filiação, etc. Pega os resultados dos exames: Bk no escarro negativo, cultura positiva.

Usuária na sala de espera pergunta se vai demorar muito porque precisa levar a neta à escola.

ENF. É um caso novo e é um pouco demorado, a senhora sabe como é. (Ela já fez tratamento de TB na unidade). Vou dar a mesma atenção para a senhora quando chegar a sua vez, tá bom?

ENF. voltando-se para o usuário pede desculpas por mais esta interrupção. Faz levantamento de comunicantes. O usuáno informa ter uma companheira e que o RX eu já foi pedido e que o laudo sairá amanhã.

ENF. Vamos esperar o laudo do médico que pediu, e se precisar, venha antes da consulta marcada. Dependendo do que o médico dizer, venha mais rapidinho.

Auxiliar de saúde entra na sala e ENF. pede que se não for urgente ela poderá conversar com ela após o atendimento.

ENF. Desculpa pelas interrupções.... Agenda nova consulta, procurando verificar qual o melhor dia para ele. - Quando o Sr. sai do plantäo?

Usuário: Este mês estou de plantão nos dias pares.

ENF. Então o senhor vai estar de plantão nos dias ímpares no mês que vem.....

A enfermeira agenda a consulta mas orienta o paciente a remarcar a consulta se não coincidir com a saída do plantão. Informa-o que os 
documentos referentes à licença médica deverão ser apresentados no seu serviço e se despede dele.

ENF. levanta-se e vai para o canto da sala conversar com o médico sobre o problema por ele trazido. Oferece a sala em que estamos (sala de pós consulta), da falta de consultório e pede um prazo para pensar até amanhã sobre o assunto. $O$ médico concorda e sai. 
Anexo 6

Legislaçāo relacionada ao consentimento esclarecido

\section{Lei $8080 / 90$}

Art. 7 - As açōes e serviços públicos de saúde e os serviços privados contratados ou conveniados que integram o Sistema Único de Saúde (SUS) são desenvolvidos de acordo com as diretrizes previstas no art 198 da Constituição Federal, obedecendo ainda os seguintes princípios:

III - preservação da autonomia das pessoas na defesa de sua integridade física e moral;

V - direito à informação, às pessoas assistidas, sobre sua saúde

\section{Constituição do Estado de São Paulo}

Art. 219 - A saúde é direito de todos e dever do Estado

Parágrafo único - Os Poderes Públicos Estadual e Municipal garantirão o direito à saúde mediante:

3 - direito à obtenção de informações e esclarecimentos de interesse da saúde individual e coletiva, assim como as atividades desenvolvidas pelo sistema

\section{Lei do Consumidor Lei $8078 / 90$}

Art. 6 - São direitos básicos do consumidor ...

II - a informação e divulgação sobre o consumo adequado dos produtos e serviços, asseguradas a liberdade de escolha e a igualdade nas contratações;

Ill a informação adequada e clara sobre os diferentes produtos e serviços, com a especificação correta de quantidade, características, composição, qualidade e preço, bem como sobre os riscos que apresentem.

Art. 31 - A oferta e apresentação de produtos ou serviços devem assegurar informações corretas, clara, precisas, ostensivas e em lingua portuguesa sobre suas características, qualidades, composição, preço, garantia, prazos de validade, origem, entre outros dados, bem como os riscos que apresentam à saúde e segurança dos consumidores 
4. Código da Saúde de São Paulo - Lei complementar 791/95

Art. 3 -"O estado de saúde, expresso em qualidade de vida pressupõe:

IV - reconhecimento e salvaguarda dos direitos do individuo, como sujeito das açōes e dos serviços de assistência em saúde, possibilitando-lhe:

b) decidir, livremente, sobre aceitação ou recusa da prestação da assistência à saúde oferecida pelo Poder Público e pela sociedade, salvo nos casos de irninente perigo de vida;

d) ser informado sobre o seu estado de saúde, as alternativas possiveis de tratamento e a evolução provável do quadro nosológico e, quando for o caso, sobre situaçōes atinentes à saúde coletiva e formas de prevenção de doenças e agravos saúde coletiva e formas de prevenção de doenças e agravos à saúde; VI Obtenção de informações e esclarecimentos adequados sobre assuntos pertinentes às açōes e aos serviços de saúde.

5. Lei $n^{\circ} 10.241$ de 17 de março de 1999.

Art. 2 - São direitos dos usuários dos serviços de saúde no Estado de São Paulo

$\mathrm{VI}$ - receber informações claras, objetivas e compreensiveis sobre:

a) hipóteses diagnósticas; b) diagnósticos realizados; c) exames solicitados; d)açōes terapêuticas; e) riscos, benefícios e inconvenientes das medidas diagnósticas e terapêuticas propostas; f) duração prevista do tratamento proposto; g) no caso de procedimentos de diagnósticos e terapêuticos invasivos, a necessidade ou não de anestesia, o tipo de anestesia a ser aplicada, o instrumental a ser utilizado, as partes do corpo afetados, os efeitos colaterais, os riscos e conseqüências indesejáveis e a duração esperada do procedimento; h) exames e condutas a que será submetido; i) a finalidade dos materiais coletados para exame; j) alternativas de diagnósticos e terapêuticas existentes, no serviço de atendimento ou em outros serviços; e l) o que julgar necessário;

VII - consentir ou recusar; de forma livre, voluntária e esclarecida, com a adequada informação, procedimentos diagnósticos e terapêuticos a serem realizados 